\title{
TRANSLABORATING WITH LEONARDO GUZZO: A CASE STUDY IN TRANSLATION AS CREATIVE WRITING
}

\author{
By
}

Alessandra Giorgioni

Thesis submitted for the degree of Doctor of Philosophy,

Victoria University of Wellington

2022 


\begin{abstract}
This thesis is divided into two elements, a creative component (75\%) and a theoretical/reflective component (25\%).

The creative component is an exercise in literary translation as a creative writing process, which consists of my complete English translation of Leonardo Guzzo's collection of short stories Le radici del mare (2015).

The theoretical/reflective component includes a commentary and analysis of the translation process in the form of a translator's diary, where the pros and cons of an extensive collaboration with the author are explored. Through this analysis I wanted to shed further light on the translation process, what it actually entails and how one can deal with and overcome the various problems that arise.
\end{abstract}

There is a tendency to focus heavily on the theories of literary and applied translation in academic literature and with this thesis I wish to highlight 1) how important the balance between theory and practice ought to be; and 2) ways in which practice can refine theory (as well as vice versa).

A relentlessly intense practice of literary translation over the course of this thesis has enabled and empowered me to develop my style and voice as a literary translator but also to garner a deeper knowledge of theoretical frameworks both directly and indirectly relevant to my case study.

My approach to and choices of translation, in general we well as specific terms, have been sharpened by 1) viewing the process of translation as a creative and collaborative experience; 2) developing a heightened awareness of different types of equivalence; 3) the ad hoc combination of foreignizing and domesticating strategies; and 4) the reflections of fellow literary translators, established and emerging, as well as authors who have translated or have been translated by other authors.

These intertwined experiences have been enhanced by an equally intense dialogue with the author at the centre of my research. There are various advantages with working closely with the writer, notably the assurance the translator can gain knowing that he/she is translating what best reflects the intentions and ideas reflected in the source text and, most importantly, the benefits of building a profound working relationship with the author.

What has proven to be a fruitful and rewarding exchange does not mean that collaboration removes limits and drawbacks - quite the opposite, as it can be a lengthy and tiring process, 
particularly when trying to find a compromise that best suits the needs and expectations surrounding the target language while also accommodating what the author wants.

When translating Guzzo's Le radici del mare, not only did I want to achieve an 'end product' that would work as a convincing case study for the purpose of this thesis, I also wanted these short stories to be able to be read and enjoyed as a literary work in English by an English speaking audience.

In order to be successful in this endeavour, I have selected, reviewed, embraced and tested theoretical frameworks and practical techniques that would enable me to achieve an inclusive and effective balance: a balance that first and foremost would let the words on the page Giorgioni's as much as Guzzo's — shine. 


\section{Acknowledgements}

First and foremost, I would like to thank my supervisors; Dr Marco Sonzogni and Dr Sally Hill. I would like to thank Marco for his continuous support and encouragement throughout my research. It was Marco that not only introduced me to Leonardo's work but also ignited my interest in translation. Thanks to Sally for her much-appreciated help in the final phases of this work. I would like to thank Marco and Sally for being wonderful mentors over these years, they have made it a true pleasure to work on this thesis.

I would like to sincerely thank Leonardo Guzzo, firstly for his brilliant short stories without which there would be no thesis, but also for his ongoing support, which has made working with him a pleasure over the years.

I would also like to thank Victoria University of Wellington - namely the School of Languages and Cultures and the Scholarship Office who made this thesis possible.

Lastly, I would like to thank my family - my parents, my grandma, my sister, and Caio for their unwavering support as I completed my studies: without them I would not be where I am today - with an extra thank you to my mother Annabel, who has read and re-read these stories almost as many times as I have. 


\section{Table of Contents}

Abstract $\quad$ iii

Acknowledgements $\quad \mathrm{v}$

Creative Component

The Translation

$\begin{array}{ll}\text { Le radici del mare } & 10\end{array}$

$\begin{array}{ll}\text { Two sports stories } & 174\end{array}$

\section{Critical Component}

Introduction

The Translator's Diary

Introduction

1. Leonardo Guzzo: his work and his view of literature 185

2. Translation as Creative Writing - What's in it for my Writing? 189

2.1 Realia: Culture Specific Language 191

3. Translation and/as Collaboration: Two Writers at Work 194

4. Testing and Achieving Equivalence: My Final Say 208

4.1 I pescatori di Cork: the fear of being unfaithful 209

4.2 La preda: striving for a cohesive voice 215

4.3 La mano del diavolo: the author's whims to the translator's whims 222

4.4 Il vento se ne infischia: the translator as author 231

$\begin{array}{ll}\text { Conclusions } & 242\end{array}$

Bibliography 
(I pescatori di Cork)

The Devil's Hand

(La mano del diavolo)

Another Sea

(Un altro mare)

In Faith, Ahab

(In fede, Ahab)

The Mark

68

(Il marchio)

The Roots of the Sea

(Le radici del mare)

The Wind Doesn't Give a Damn

(Il vento se ne infischia)

The Prey

(La preda)

Borges' Atlas

(L'atlante di Borges)

Finis Terrae

(Finis Terrae)

A Shade of Blue

(Un tono d'azzurro)

*Two sport stories

The Idol

(L'idolo)

Beco

(Beco) 


\section{The Fishermen from Cork}

1.

"Rain clouds".

"Rain clouds? Why?"

"Blue, dense and formless. They seem like the sky and instead they are clouds".

The same mist enveloped the sky and the sea. In the thick curtain fog, two men gently manoeuvred a sailboat as if it were as delicate as a twig. It was hard to say how far from the coast they were. The horizon was barely visible: it appeared as if the boat were sailing through the air.

“Jack, put your hood on. It's coming..."

Jack put his rain jacket hood on. They both knew that there would be no shelter from what was coming. This time they were not going just to chase the kerke, as they had two months before. "Three miles off the coast of Kassiclanagh. Our calculations were correct: it was three miles off the coast of Kassiclanagh. That's when we saw it. The others can think what they like but we know that we saw it."

Suddenly, the sea had opened up to show a fin the size of a hill and tentacle as long as the road from Cork to the nearest village.

"God knows how we are here to tell the tale."

"This time is going to be all the more terrifying. The mother of all the other times. May God protect us..."

Jack Evans and Sean Morrissey were fishermen. But they were a particular type of fishermen. their goal was to catch sea monsters. On this topic, they were the most knowledgeable in the whole town, perhaps even the whole country. They had hundreds of books and manuscripts on the matter and every year they carried out dozens of expeditions. One time they went as far as 
Iceland to meet with local experts deep in the fiords and exchange information on northern sea monsters. But this time felt different. The day before, an hour before sunset, they had left Cork with a strange expression on their faces, as if they were going to face their destiny.

2.

From Sean Morrissey's logbook: “Ictyoforus Biphidus is described as one of the marvels of nature. It is a living creature, greatly resembling a prehistoric monster. It has the body of a fish and is covered in scales but with the limbs of a large lizard and the head of a snake with two rows of sharp teeth and stony eyes. The dimensions are unclear as this differs in various accounts, some describing a sort of dragon or an enormous crocodile, in others it is no larger than the largest species of Monkfish. Its appearance is always preceded by foreboding omens of death and woe."

The Ictyoforus appears in many a Celtic myth, grim tales in which it is said to guard terrible secrets and even the very meaning of life and death.

It lived in the pits of the ocean, thousands of meters deep, but every hundred years, when the stars aligned and caused a subtle change in the temperature, affecting the tides down in the depths of the sea, then it would resurface to reveal its secret and to determine someone's fate. Jack Evans and Sean Morrissey had always hoped that that one day, every hundred years, would be in their lifetime. They had been preparing for this for a long time, reading every account of previous apparitions, studying the changes in the stars and charting the various courses on the nautical maps. The previous day they believed they had finally identified a sign. They had gone down to the sea, down the stone staircase that led them to the boat ramps, and straight to the pier. They had pushed Seawyle off into the water and started loading up the boat with equipment: fishing lines, cages, nets to capture it, the lamp so they could track the monster's nocturnal movements; all gear they had bought from old man Seamus Hewitt's shop. 
If it weren't for their continuous and adventurous expeditions, old Seamus would have closed his shop doors a long time ago due to lack of customers. The whole town thought he was mad because he heard voices, spoke to the shadows and talked the most outlandish nonsense ever heard in Cork.

But these two fisherman felt differently. They did not think the old man was mad. They found his ramblings to be perfectly plausible. Old Seamus had taught them everything they knew about sea monsters. The names, descriptions and the most incredible and terrible tales. He was now well in his eighties and was almost completely blind, but he still knew how to set a trap or gauge the lead line better than anyone in all of Cork.

By the time this was all done, and the two fishermen set off, it was an hour before sunset. They might as well have been invisible, for nobody paid any attention to them leaving.

In fact, they were not particularly popular in Cork. That is to say, everyone knew of them, but no one knew their faces. They did not go to the town meetings, and they tended to lead a secluded life. Secrecy — they maintained — couldn't help but make their peculiar task easier, and after all, there wasn't much to see in the town.

Nothing had changed in Cork for at least the last fifty years and who knew if it had ever been different. The power lines ran for miles over the pastures dotted with houses, freshly painted in bright colours, which were scattered from the beach all the way up the cliff.

But the number of funerals was steadily overtaking the number of marriages. In fact, the new priest was yet to perform a single marriage. People were starting to leave.

To their great surprise, the people who escaped discovered that time carried on outside of Cork. For the others, those who decided to stay, life remained exactly the same, day after day, as if they were in an eternal world.

"Cork is the perfect place to practice for eternity," old Seamus would say. 
3.

At that time, during the week before the last Sunday of Advent, in Cork they would collect wood for Christmas Eve. They would comb the beach for miles, scavenging for logs, twigs, driftwood and anything that the sea had left behind. Then, in groups, the townspeople would tie up the heavier bits with rope and drag them up to the square in front of the church - the dog-tooth church - for the Christmas Eve fire.

Every village in the county, whether on the coast or inland, would light fires on Christmas Eve. They burnt huge piles of wood and flotsam and the flames rose tens of meters high.

The sailors out at sea would call it the Night of Fireflies.

From afar, the coast glimmered and shone, becoming a spectacular display of light.

No fires had been lit along the coast the night before. Instead, the two fishermen had relied on chasing the moon as it hid behind the clouds.

They weren't following any particular route. The monster would certainly be resurfacing from the depths, attracted to the light. It, too, was following the course of the moon.

They had lowered the traps and lead lines without any hope of catching the monster. The monster would not be intercepted that easily, never mind caught. But they might always come across a school of fish or some other creature from the deep and take note of how they moved, to see if the monster could be close.

Unfortunately, they had yet to see the shadow of a fish worthy of its name. They had only caught sight of the occasional herd of seals swimming swiftly towards the shore.

People around there believed that the souls of the dead were reborn as seals and so they treated them with the greatest respect and saw their presence as a sign. It was believed that seals should be followed, for they knew the sea well and had a glimpse into the depths of the mysteries within. 
But the fishermen pushed on, choosing to ignore any warnings from Aaron the hearth god. If they had wished to heed the warnings from the deities that protected them, they never would have left the shore. Not even the first time when, as children, they had decided to go into the Ballyshine swamp.

4.

Sean Morrissey sat at the stern, steering the course by manoeuvring the prop-engine tiller. Jack Evans was at the lookout post, with one foot planted on the boards in front of the bollard attached to the prow. He stared straight at the horizon, trying to read the signs of the current. Perplexed, he rubbed his beard. He looked like a seaborne saint.

The two fishermen stood still in their positions waiting to be flooded with light. They expected that at any moment the wind would turn salt-laden and the sky would fall and a swarm of silver would quiver under the water. Instead, the Seawyle sailed calmly on. It seemed no snare could threaten its course.

The sea remained completely still, no crashing waves nor sprays of saltwater, only the lull of the tide. The propeller stirred up a lazy white mass. The harpoon lay on one side of the boat, brand-new and shiny, glinting whenever it caught the sun.

"The storm has been looming for hours... if only it would just pour down, Jesus! I wish it would just pour, that wonderful sort of rain, without a breath of wind: continuous, rhythmic, vertical like the thread of a well-weighted line".

The rough sea storm season had begun, and the fishermen themselves had already seen rain clouds fill up above their heads as a storm engulfed the sea and the waves chased them into the cliffs. 
Sean Morrissey detested that flat calm. He would have preferred a thousand times to dance on the waves with the risk of being shipwrecked or even, at this point, to have stayed at home to enjoy the peaceful amber light of the silent and slow sunset over Cork.

"At least come, if you must come at all!" he snapped.

Something felt very strange to Sean. There was something different about this time. He felt uneasy.

Now that he thought of it, something else struck him as odd.

He couldn't remember a time when there wasn't a single boat in the Cork Harbour: this image did not exist in his memory.

But now he swore that the day before, as they left, the harbour had been empty. Completely deserted. And what's more, during their entire voyage, even before they reached the open seas, they hadn't seen a single soul. Not even one of the oyster fishermen who usually were scouring the coast in hoards, that time year.

The rain did not come. Instead, the mist thickened and turned into fog, a thick dense cloud of fog. On board, they were barely able to recognize the Atlantic: the Ocean that echoed the sound of thunder, that hosted unfathomable depths and iron-clad predators. Where they were, did not seem like the middle of the Ocean. Nor did it seem like anywhere real. It was as if they were stuck in an opaque crystal bowl and, outside it, nothing else was left.

As they faded into the fog, Cork seemed so far away. And everything else slowly vanished... like the start or the end of a dream.

5.

When the fog was this thick, the fishermen of Cork did not trust going out on the sea. And so the beach was busier than usual. A group of no more than fifteen men were gathered around a huge oak log that had crashed into the shore during the most recent storm. They were securing the log so as to drag it along the beach, as close to the town as possible. All of a sudden, some 
women from the village appeared at one end of the beach, and as they got closer, you could see they were stepping carefully on the ground as if to test it. They also walked this way when they went out to the fields in the middle of the day, to spread the tablecloths and set the table for lunch behind a hedge. But the sound they made signified something serious had happened. The men did not ask for any explanations. They stopped dragging the sodden log, leaving everything as it was and went back to the village. They grabbed whatever they needed and in less than half an hour they were walking to the marshes.

Seamus Hewitt led the expedition: a dozen men with torches and armed with scythes and rifles. They moved through the woods delicately as if searching for mistletoe or hawthorn berries. The water dripped off the alder trees soaking their hair and their feet sank into the wet grass. But their hurried pace, and the sense of dread suggested a heavier - and tragic - task ahead of them.

That morning the marshes had relinquished the bodies of two children. Peat diggers crossing the marshes in their raft hit something with one of their poles and immediately rushed back to the town to tell their story. Their few vague words gently extinguished any hope.

But the townspeople did not want to accept anything but evidence. So, the women had told the men what they knew, and the men decided to leave for the marshes with the peat diggers.

A few people would habitually gather in the town square to chat, mostly the elderly competing for who had the most ailments, but today they discussed ... the missing children and the expedition that had been sent out to find them.

It seemed it was always the same old people but the frequency of funerals that year said otherwise. The women retreated to the church and said a rosary. Their prayers were filled with familiar and yet unintelligible words such as "providence" and "God's will" and others that were even more obscure and odious, such as "fate" and "destiny". They built a fortress with these words to hide their powerlessness and the sense of resignation they felt. Meanwhile, the 
search parties in the forest were trying to complete their task as quickly as possible. The earth and the sky ran through their hands; in their minds rang the prayer vigils, the candlelight flickered and the priest continuously repeated "Have faith in Jesus". Heedlessly, they scrambled over the roots that grew along the top of the ground, slipping on the carpet of fallen rotting leaves. They didn't feel the sting of ice and holly. Nor did they notice the apparitions and murmurs amongst the forest fairies. They clung to their hope, though that was waning as time went on. They too were hunted spirits wandering in that dank, drizzling place. Seamus Hewitt was ahead of the rest hacking through the dry, rampant branches that obscured their way. At times the undergrowth was so dense that only a small child would be able to make his way through without much difficulty.

O'Brady, the Mayor, skittered like a bat lagging behind the group. He had trouble keeping up, and in turns someone, cursing, would stop and waitfor him. At dusk, a breeze picked up and it seemed as if the forest were sighing out mist. Where the forest ended at the bottom of a valley, where the Movola River had overflowed and covered the steppingstones, the search party was forced to wade through the muddy waters, cutting across the river and hurrying over the gravel. They found themselves in a clearing surrounded by mistletoe bushes and in the distance, they could see the marsh reeds.

They started to run again. Faster, their legs submerged in the fog. They kept going until they noticed the acrid smell of the swamp and their feet sank into the thick waters that had clotted along the bank. The ground was the texture of ripe fruit pulp and gave way under their feet. They still hoped for a miracle. For the love of God and their faith, it should happen.

6.

Then it did happen, the miracle they had been waiting for, when they least expected it. 
A few meters away from the fishermen's boat, the water started to bubble and then to flow upwards as if a submerged volcano was erupting. The propeller went idle and Seawyle reared up above the waves.

The monster appeared. It emerged, hunched over as if it had just emerged from a vial in the workroom of a biologist. It had the body of a fish, from which protruded four webbed feet, and the skin of a reptile, smooth and scaly with a ridge on its back. Its eyes were round and bulbous. They were black and pupilless. The monster leapt out of the water and dove back into the waves and again it leapt, each time higher and slower, as if it could hover in the sky.

In the end it paused in mid-air, looming over the boat. Sean Morrissey was frightened, yet he raised his pirate eyebrows and looked defiantly at the creature.

"Now amaze me with another miracle."

But the monster remained motionless, suspended by a mysterious force, encircled by light, as if it were about to do something or rather as if it were lying in wait.

Jack Evans decided to do it his way. He attached about ten metres of fishing line to his harpoon and ran to the edge of the boat. Then, with all his strength, he hurled it at the creature. The harpoon whistled through the air, flashing as it struck the monster. It left a gash, right in the centre of its body and slowly it began to rip open. Inside, its body was all black, the same unseeing black as its eyes. The gash continued to widen, revealing a bottomless depth which glowed like a night sky full of stars.

The wound became even larger, larger than the creature itself, until it engulfed the mist and the endless sea. The water flowed into the emptiness as if falling from the edge of the world. Until even Seawyle and its crew fell irrevocably into the looming abyss, into the unknown. Jack Evans and Sean Morrissey could clearly see what awaited them. They caught flashes of objects and glimpses of people in the starlight. And under it all, they began to recognize 
themselves, as they had been many years before, when they used to play in the Ballyshine Marshes. The sky suddenly darkened. They were inside the monster.

"Is this real?" Jack asked.

"As real as we are."

"Is this what we came for?"

"Yes, it is..."

They were there to retrieve the bodies of two lifeless children. But now the search party prayed to the heavens to relieve them of their thankless task. Now that the time had come, they weren't ready. As they laid eyes on the corpses, they became still. Butchers and sailors of the seven seas could not bear the sight of the children being pulled ashore with poles. One person lit a torch: the bodies were purple, swollen and covered in mud. Their wrists were stone cold.

Their half-closed fists were like buds before they bloom, and their hair resembled a nest of soaked straw. Their veins created transparent patterns on their pale skin: visible on their temples, their necks, their legs bare from the knee down.

They were still intact, no visible wounds. The black waters of the marsh had preserved their little bodies like that of a saint. Seamus Hewitt recognised them immediately.

Once the Doctor had fully examined the bodies, he concluded that they had drowned. Most likely they had waded into the marshes and the muddy treacherous waters had swallowed them up. When they returned, the town would mourn for two or three days, before resuming preparations for Christmas in the hope of distracting from the tragedy. But the people of Cork, so devoted and overwhelmed by omens, would not forget. They would bury them, they would cry, they would pretend to, but they would not forget.

As those men dragged the bodies back through the brambles, they let out a blasphemous scream. "Why?" The question rustled through the forest on the way back.

"Why?" 
7.

In the darkness amongst the stars, Sean Morrissey understood.

He took solace in the friendship of a night spirit, for everything he had pursued fruitlessly during the day suddenly became clear to him at night.

Jack Evans did not need to find solace in friendship, but he understood anyway. Together they felt an immeasurable sadness. A sadness that didn't exist.

At the church in Cork, it was time for the sermon. The priest stood at the altar and began the commemoration of the two dead children. His voice began to break as he spoke to the crowd of how the boys had always dreamed of becoming fishermen, how they would go out to sea to hunt sea monsters. He let out a sob and finally surrendered to divine providence. Beside the white coffins, two huge candles smoked. Seamus Hewitt and Big John Rowley - the boys' godfathers - ended the ceremony with the saddest of rituals, snuffing out a candle for each of the tiny victims, snuffing out the candle as if to snuff out each life and all its dreams.

A cold glitter of souls

Through some far briny zone.

Even Christ's palms, unhealed.

Smart and cannot fish there.

Seamus Heaney, 'Limbo' (Wintering Out).

The priests last words were engulfed in flames. Aileen Morrissey and Sheila Evans wept for their children. 


\section{The Devil's Hand}

In the year of the Lord 1571 an event took place, the most terrible battle in the memory of the sea. The final judgement, some called it, the bloody showdown between two armies and two worlds. Two hundred and fifty ships united under the crescent flag collided with the most imposing Christian army since the times of the crusades: a little over two hundred galleys, set sail from Venice, Spain, Genoa, Malta and led into battle by Giovanni of Austria, the brother of his Catholic Majesty. Off the coast of Lepanto, in the Gulf of Corinth, an epic battle broke out, that promised glory to the winner and barely disguised the beginnings of an end. The Lepanto battle was the last one fought with boats powered by oarsmen, fortresses floating on the agony of a humanity both invisible and desperate. The oarsmen - either relegated to the hold, hidden away from the sun, or completely exposed to the elements were the soul of the ship, the secret of its movement. They were the wind, like a breath or a spirit, an element of nature.

They were, for the same reason, either a throng of devout believers or a hardened godless mob. They worshipped Christ or Allah or money or simply themselves. Some worshipped symbols, idols, a coat of arms, nameless gods of the hearth. Others worshipped the sword or the herd or the oases and the desert jasmine. And then there were others who worshipped speed, recklessness, risk. Death would come sooner or later but couldn't hurt them, no more than the lesson they had already learnt from the pain. Nothing could hurt more than the wound, the deepest one, carried within.

Their suffering, offered up to the sun or hidden in the darkness of the hold, was like the glory of a martyr; the clanking of the irons evoked a strange masculine thrill. The battle fought all around was the stuff of another world, something of little interest to them. It had nothing to do with their own personal despair. 
It had just begun, only a few hours before, but already it presented as a business of strategies and battle lines and soldiers and names without faces, Nations and History. The Christians came from the open sea in a single line of ships, apart from a small group left in reserve. The Turks, greater in number, had let themselves be bottled up in the bay of Lepanto and now they were trying to break through, driving forward into the right flank of the opposing army. The battle became uncertain when the Maltese galleys sent out their alarm signal. Under the command of Marquis of Santa Cruz, the reserve crew itself raced frantically towards the centre of the struggle. The battle raged on fiercely. Christian and Muslim soldiers were each other's incarnation of evil. The Order of Malta's three galleys, just three, withstood the impact of the entire left wing of the Turkish fleet. A wafer holding back an avalanche. One small crack now and nobody could have stopped the Turks from taking over.

Santa Cruz's crew barged in without caution, the culmination of a risky and desperate manoeuvre. The sailors of the Order engaged in face to face combat with the infidels, in a cloud of smoke and gunpowder. The mouths of the cannons - some close, some far and some further still — roared a deafening bellow.

The cannon balls traced perfect arches in the sky, long trails of fire and cloud. Their victims regarded them with indifference at first, seeing the cannons go off slowly far in the difference, but then came down in a lethal curve of devastating consequences. A strike of fate, or so it seemed, prepared in secret and inevitable.

The "Marquesa" had the thankless task of being the bait. The first ship coming to the rescue usually took all the brunt of the enemy artillery and was destined to be sacrificed. The "Marquesa" was no exception. The cannons opened fire and one by one blew apart the rostrum, the forecastles, and sections of the outrigger right down to the canopy over the stern. Instead of beating a pointless retreat, the captain gave the order to speed up the raid. The 
slave drivers sharpened the whip, the rowers doubled their momentum. They spat blood and cursed to the same God that the sailors up on deck had invoked as their banner. The "Marquesa" arrived at the middle of the brawl under a downpour of fire, stripped of its gear, akin to a drifting wreck or a dismal ghost ship. The umpteenth close range shot made it tilt on its left side, it remained like this for a long while taking on water until in finally sank.

Bedraggled and confused, the few remaining survivors of the crew leaped from the bulwarks to the deck of the Turkish flagship and there they fell. Perhaps they were misled by the Order of Malta flag that had just been taken from the Christian galleys. Certainly, they hoped to have better luck than at sea.

The reckless move by the Marquis of Santa Cruz broke the enemy line in two. Most of the left wing remained stuck on the south side of the Gulf of Lepanto with no way to escape. But a small vanguard, left out of the battle, managed to sail off. In charge of it was the infamous Barbary pirate and bloodthirsty terror of the seven seas, Uluch Alì. A few men and some lords of the kingdom of Spain unwillingly belonged to that vanguard too, as they had ventured too far in order to snatch the Knights' flag from the infidels. From the deck of that flagship they watched the battle continue from afar, numb, terrified of their fate, enveloped in a feeling of futility. They were the flip side of the victory.

As they drifted away who knows where, they could still make out the Turkish fleet surrounded and under siege, ship after crushed ship, swallowed by the sea. In the $949^{\text {th }}$ year since Hegira ${ }^{1}$ the Barbary fleet was defeated and destroyed. The few surviving ships were left to take their chances elsewhere, filled with hatred and despair. The fate of the Mediterranean had been decided for centuries to come.

\footnotetext{
${ }^{1}$ Prophet Muhammad's departure from Mecca to Medina in AD 622, marking the consolidation of the first Muslim community [translator's note].
} 
From the moment of his capture, one of the Christian prisoners had been bleeding profusely. At first it had gone unnoticed: the crew, absorbed in their ploy to escape the Marquis of Santa Cruz, had paid no attention to it. But no one could allow themselves to lose such a valuable ransom. A very important person from Spain or the Viceroyalty, the corsairs figured out, having already got a good look at his rank. In his pocket they found a handkerchief with his name embroidered in gold letters, a tradition of Hispanic nobility, and two letters of introduction addressed to Don Giovanni of Austria, stained by the blood from his wound. You couldn't tell where the blood was coming from. The man was crouched down and on his lap he was tightly grasping a reddened rag.

You couldn't see where he was bleeding from or how large the wound might be. Not even Don Miguel knew exactly how much damage he had suffered. He knew something was wrong, his brain told him, but he refused to look. He concealed his wound with a bloodsoaked bandage, held tightly with his right hand, as he staggered about, exhausted by fever.

In that floating hospital of the infidels, the prisoners were treated with great care. They needed young strong men suited to slave labour. A dead young man was not something they wanted either. When Don Miguel lost consciousness and could no longer oppose them, the stretcher bearers removed the bandage from his left arm. The macabre revelation was that his hand had been severed at the wrist, the wound spurting blood and at risk of infection. A barber-surgeon was called urgently. He made some incisions to stop the haemorrhage and sewed it back up. He applied ointments to lessen the pain and quicken the scarring. Then he tied up the stump tightly.

The patient spent his convalescence down in the hold, which was now an improvised infirmary, on his face an expression of permanent offence at the workings of fate. Contrary to 
every prediction, his body reacted well and quickly, which seemed to offend him even more. He had imagined himself drowning in a helpless pit of despair, accepting the ailments that always come with convalescence of a serious injury. But his own body mocked him. He was a sick soul trapped in a shell of rude health.

In the first few months, what's more, Don Miguel was afflicted by a distressing apathy and a complete loss of appetite. They had a 'janissary' watch over him to ensure he didn't make reckless mistakes. At night he howled, demanding revenge on the woman who had betrayed him and begging to be forgiven for the blood he had shed. He persisted in his search, must his life really take this path or was it nothing but a vile joke of fate? If he'd only been less ambitious, if he'd chosen another woman, tamed his passions and respected the rules of cavalry, if he'd only refrained from killing in order to wash away his shame, if at least he'd seen the cannon ball firing which blew off his hand... he would have been happier, yes, he would have been happy. The son of a Spanish Grandee, betrothed to the princess Catalina Salazar y Palacios, guard of honour to His Catholic Majesty: perhaps once his happiness had to do with all this. But he could have given it all away without regret in exchange for that other happiness he was chasing now. He would have even been happy as a poor shepherd of a flock in the Meseta.

After a week he got out of bed. His purulent wound still caused him to suffer and shake in pain. They placed a mirror in front of him to shave him and reassure him of his progress and they had no idea they were throwing him into Gehenna.

Looking at himself in the mirror was like recognising a mark of disgrace, just like reading his own condemnation on a blank page, the paper rough and sharp. It was written. Long before him it had been passed down, in spoken word, written in stone, on yellowed rolls of parchment. He looked at himself and read there a dark, deserved guilt that he was dragging 
hidden from the sun: he bowed to withstand the relentless tone of the law. "There is no pardon for what time sweeps away". His sense of perfection - human, physical, mortal perfection - should have died forever. Out of the cocoon of pleas and superstition, Don Miguel began the walk of shame: with anguish weighing on his shoulders, the bags under his eyes revealed all his faults.

By the end of the fourth week he was put to work. The doors of the hold were opened and he was thrown in between the benches of the pit where all the oarsmen stared at his severed arm, as if mesmerized. To deal with his impairment, the Arabs put his stump in an iron ring, fixing it to the oar, in a way that followed the movement of his shoulder. Even without a hand, the left arm of Don Miguel "rowed".

It had little worth for him. A ploy that pretended to make him like the others, didn't change anything at all. Looking at the empty space where his hand had been drove him mad. He decided to not look at it anymore, but it was impossible since the oar stayed permanently in his eyesight. So he began to row with his eyes closed. He rowed in a frenzy. He was spurred on by the men who held the whips and strained himself twice as hard so the boat would arrive earlier. Why, and where, wasn't important. Whatever it was, it needed to be done "earlier". It's hard to describe Don Miguel's personality. In fact he had become a completely different person, from the man he was before the accident. The ambition, the joy to be alive and his own desire for adventure created an unresolved jumble. Depending on who observed, and how he felt at the time, he could be perceived as an unbearable braggart or the perfect example of a bon vivant.

He was carnal, impulsive, he picked up desires from around the world and poured them over his body. This at least had not changed. Rather it had only become heightened, turning him into a clot of blind force, an incandescent mass of fury. 
In short, the legend of a fearless Spaniard, who rowed for ten and did not suffer hardship, spread a board of the galleon and amongst the ships of the whole Turkish navy. Because of him the ferocious Uluch Alì, the last disciple of the Barbarossa brothers, accomplished memorable feats.

Since he had been chained to the benches, Don Miguel's imagination travelled wildly. Barbary pirates ventured along wondrous routes, they sailed to the thriving ports of North Africa, Asia Minor and the Near East. The prisoner was allowed to go ashore to be sold in the slave auctions (his were always deserted); he was seldom given permission to go up on deck to see the vast views not visible through the circle of a porthole. But he preferred to follow the movements of the ship with just his imagination. He always dreamt of those places he had imagined, fathomed them in his mind; and now those places were more beautiful in his head than they were in reality.

In his hours of rest, every time they stopped to get supplies or during the calm nights out at sea, Don Miguel wrote. Bent over, under the light of the oil lamp he concentrated. In the ink he was searching for the stuff of the stars. Perhaps in some way he was aware that faraway in Flanders artisans were building an optical contraption to see the stars, the moon, the sun and all the alleged satellites of Earth up close.

Few heretics, like the apostles in Palestine, opposed the Ptolemaic system, but their folly had the unmistakable reek of truth. A true revolution that would shake the foundations of the known world and Don Miguel wanted to be a part of it. A severed hand was not going to prevent that.

On board, many odd stories were told about Don Miguel's occupation. Members of the crew thought that he consulted some sort of Kabbalah or compiled Ephemeris and so he quickly 
found himself surrounded by an aura of mystery, almost like a necromancer or a grand master of alchemy. One night, at the end of a shift that he had begged for from an old Cretan, the threatening face of Uluch Alì appeared in front of him.

"Are you the Spaniard with the severed hand?"

Don Miguel twirled the stump inside the ring attached to the oar.

The captain resumed his threatening tone once again.

"In Islam the left hand is hostage to evil spirits. It is the evil hand, the devil's hand. The faithful only use it for intimate and impure tasks. To someone, some zealous man of my faith, your severed hand could even be seen as a sign of destiny, and you as chosen to be converted. But not to me, unfortunately. I follow a different doctrine".

Uluch Alì's eyes flared with a captivating reddish glow. "The ambition... the pleasure... the sublime pleasure... the search for perfection. Find your demon and let it guide you".

Don Miguel had stopped paying attention. He ignored any form of consolation. He stared at the oarsman in front of him with watery eyes, absent-mindedly.

Alì kept watching him. For him too, the evil was the result of trauma.

An abyss of compassion opened up in his menacing look.

"Do you Christians know Avicenna? It would appear your ancestors inspired him. Have you ever heard of Plato or Aristotle? Experience fosters a higher consciousness: something is lost and something else is gained. It's the logic behind trade, after all, and it's also how marauders do business. Looks like we're all philosophers...".

Don Miguel had studied at one of the best colleges in Spain and knew perfectly well about ancient Greece, but he chose not to answer. With a little luck, if he showed his knowledge, he could have been an assistant alchemist on board. Or perhaps his theories would have seemed too strange and he would have only attracted suspicion and punishment. In the end, the 
prisoner remained silent. Harbouring all that fury inside, rowing at the bench, was the best way to prove himself.

Alì began to think that the Spaniard really was "blessed" in some way. For twenty days he had the man deliver him a part of his lunch, as a sign of respect, and after the umpteenth refusal he had him brutally whipped and then he had a marvellous soothing ointment that came from the Orient poured on the Spaniard's wounds. He acted like a possessive lover but he had other plans. He was determined to accomplish an unprecedented feat in pirate history and needed that man to help him.

In the year of the Lord 1572, the nine-hundred-and-fiftieth since Hegira, the galleys of Uluch Alì pointed their prows toward the most remote stronghold of Christian Europe: The Canary Islands, those very islands that served as a supply base for the ships on their way to the Americas and would welcome their return as they landed laden with lavish treasures. It was an unusual journey for the Barbary corsairs and Don Miguel's experience and knowledge of nautical charts and ocean routes, would be very useful. Nevertheless, the journey was made in unfavourable conditions and they faced hindrances of every sort.

For about a week the pirates fought against unfavourable winds and then, as the wind changed, they were hit with the stifling heat that came from Africa. One after the other, the rowers fainted from exhaustion. They had been rowing for days at a slow pace and the heat in the hold tormented them. They were suffocating. The thrill of the whip brought relief. From time to time the slave drivers would wet the backs of the oarsmen, with strips of watersoaked cloth hung on long poles. Every half-hour the cabin boy would go among the benches and poured a few drops of water from a flask into the mouths of the slaves. The guards kept hurling insults over the continuous complaints, but it was pointless. In the hottest hours it seemed as if the boat was still in the water, at the mercy of the currents. 
Suddenly there was silence in the hold. Their pain was Hell-like and only then did the slave drivers curse their task of tormenting them. Don Miguel rowed with his eyes closed. Everyone clung to what they had left: they were again becoming faithful Christians, villains converted to Allah, preachers of speed, worshipers of death.

The heatwave forced Don Miguel to open his eyes. From a porthole he saw the free open ocean, without keels or moorings, ghosts or monsters. A vast desert and his soul was like that. He suspected that the salt-encrusted glass captured his reflection.

A distant blurry projection.

Viewed up close, however, his soul resembled a chaos of elementary forces or an omen of the end of the world. Dunes disintegrated under the sun, peat and coal, grape skins fermenting, the residue of a mutation, a pellet of thorny mouthfuls forced down secret pathways. Before anyone came up with the expression, in the depths of his conscience he had "wiped the slate clean". Now he carried around a vacant soul.

Nothing else remained. Nothing but crags and precipices, narrow paths as delicate as seams of alabaster. After the scream, the prayer and the despair, the moment of surrender had finally come.

"Your hand won't grow back". "Your hand is not a lizard's tail".

He bent over the page and wrote those few sentences.

He had really believed it. He thought it was only a matter of time, accepting that things don't always happen immediately. When he realised this wasn't the case it gave him a nasty shock. He got up dazed, almost staggering. He resisted the impulse to turn around. 
It had been a long time since he had looked in a mirror. The image he saw reflected in the glass did not exist in any part of his mind. Which is why it upset him, offended him even. He couldn't manage to see himself how he wished. He looked at his flaws and his defects, permanent by now: the reflection in the mirror was an encyclopaedia of all his mistakes. So he stopped looking at himself or even thinking about himself. He stopped loving himself and loved himself in another way. With compassion, from the soul for the body. From his soul, a higher soul in the form of an eagle, for his poor body.

A few hours later Uluch Alì's fleet reached its destination. After weeks of switching course and various tribulations, the lookout on the main mast saw Gran Canaria. A village appeared on the horizon: a row of white houses along the coast and a whole bunch of others further inland, clustered around a sort of fortress. Guarding the marina there was an unfinished square tower, with battlements and five openings on each side.

From where they were, Alì lead the ships - with their flags hidden - out of sight from the village, behind a point from where they launched the attack at the hour of evening vespers. The Barbary captains quickly consulted with one other. They placed the ships in a shooting formation, facing the coast at what seemed to be a safe distance, and opened fire. The townspeople up in the castle tower retaliated, under an avalanche of shards and rubble they fought back; but the defensive fire did not even scratch the ships moored afar. Uluch Ali, that devil, had guessed right. The cannons in the tower had a shorter range than the pirates' artillery; in short, they were defeated without inflicting any real damage. Then many dinghies - called skiffs - left the pirate ships and made their way to shore and many assailants landed on the beach. The first to make it ashore began shooting incessantly to protect the others as they arrived. They descended with primal fury, crushing anything that stood in their way. 
A Christian battalion of seventy, led by the usual captain with a shining helmet, came forward and stayed in a skirmish for a good few hours before withdrawing. The Turks were able to take over. They advanced in a confused manner, crying out and wielding their sabres. It seemed that they were not going anywhere nor looking for anything in particular - the only thing they were doing was making a racket. A bloody revelry. As they approached the village, they raised their flags upright. This meant they no longer considered themselves marauders but soldiers in the perpetual struggle against the "enemies of faith". They wanted to be known as the heroes of a holy war and in the meantime they scaled the city walls and appeared amongst the battlements, expecting to be caught by the guards. They knew they would die but amazingly, even after the blows and the terrible fall, some of them were kept alive by the fury harboured inside.

At the foot of the walls the leaders were already devising a way to enter the fortress. The Turks gathered like ants in front of the city gate. They sank their axes into the wood and drove their battering rams into the gate, stepping on the backs of their fallen comrades and even grabbing their torches to set it on fire. The soldiers on the inside tried to hold out, to patch up the walls that were meant to hold back every attack and in the end they fled, from place to place up to the last hiding place of the fortress. The Turks were superior on the battlefield: they wandered about collecting their spoils, setting things ablaze and there they remained.

The ships were left at sea with no one aboard. Don Miguel's galley was empty, bar a few sentries. Slaves and converts alike had gone ashore and followed the attack in the rear. This was their first attack and they were eager to see it for themselves.

But not him. He had done his job and now he didn't want to see.

"Better to enjoy the mid-month moon, bright as day in the sky." Better to imagine. 
The Turks remained as victors on the battlefield wandering around collecting their spoils and not going anywhere. They went hunting Christians but the Christians did not want to be caught and that was when the things he couldn't bear happened. For hours, and with contempt. With ever increasing disgust and fatigue. Until finally a strange peace that smelt of destruction set in.

Don Miguel already knew it all. He also knew what would happen afterwards. There would most certainly be a trial. All to say that the soldiers had done their part and fulfilled their duty. That the alarm was raised, and the artillery was fired into the distance, and so there was no need for the cavalry or the naval team to guard the port. They would make out that the pirates' spoils were meagre, turning a blind to the garments, the linen clothes, the goblets and the golden tabernacle that were loaded onto the ships that very night. They would swear, on their word as a soldier, that there were no casualties among the citizens and the army. At most, some had been injured. In the records there would be no mention of the corpse of a Christian sentry, found on the beach where the pirates landed. There would also be no mention of the deportees: an old man, a few children unknown to the authority, a couple of adults able to work at a bench. And a beautiful woman, whom Ali would enslave and whose fate Don Miguel was certain of as soon as he saw her.

"You will regret leaving me".

He was almost certain he knew what fate had in store for another woman.

"Whore".

The woman who had betrayed him and forced him to leave Spain.

"You will regret leaving me". He spoke as if she were in front of him.

She had to regret leaving him. 
Not again, not now, after this memory had worn him out. But one day, when her blood would run cold and with it blind desire, then she would regret leaving him.

She would call out to him during the night, under the star light, next to a man she wouldn't recognise; she would search for him with the fury of a siege.

And he would stay where he was. He would hear her call from afar and despise her. He would grow like a tree, big and strong, with its roots planted in the good earth.

The beautiful woman vanished and as her dress rustled, the ghost of the other woman vanished too. Don Miguel was sure of his mind. He pulled his severed hand out of the ring and when he punched the oar he felt almost no pain. He knew this wasn't true. He looked at his missing hand and cried.

Day after day the prisoners adapted to life as best they could. Some chose their own destiny, others had theirs chosen for them. The old man pretended to be a doctor and converted to Islam before the Turks discovered the deception, he was a doctor no more than a donkey is a thoroughbred. When it was the time to pray, the children were trained by the whip, the rough boards of the deck and everything else needed to make angry ruthless warriors out of them.

The woman stroked her swollen belly with shame and tenderness. She had wanted to be the wife of a dignitary of the crown and now she only wanted to be a good wife of a corsair. When he returned Don Miguel saw her again, she was as beautiful as ever, and he staggered when she smiled at him. The ghost of the other woman brushed against him and then vanished into thin air. He restrained himself even though he wanted to respond. Smile. He didn't pretend this time, out of nerves or some other impulse. His stomach turned as he tried to speak, there was a lump in his throat. Now Don Miguel began to understand. To love for him meant to survive. Hope, like a blue sky, had broken the cross. Hope, like an emptied tomb, a shroud removed and laid down. Hope had won over death. 
He would never again have loved so purely. But still, he knew, beauty would come back to hurt him. Again he would turn in dizzying circles, at one with the spinning of his eyes. $\mathrm{He}$ would cry, scream, tugging at the fibres of his heart until they wore away. And then, at the end, he would be still alive.

On the day of the summer solstice in the year 1572 the Barbary fleet reached the port of Constantinople. Satisfied and content, Uluch Alì had paraded through the Mediterranean to be appointed Kapudan Pasha, Commander-in-Chief of the Ottoman Fleet by the Sultan. Public celebrations were held, slaves and prisoners were freed in gratitude to Allah. But not the Spaniard, who by then was part and parcel of the wheelhouse, and not the hostages from Canary Islands, the living proof of Ali's triumph. The fake doctor, the beautiful wife and the future warriors of Islam were paraded. Don Miguel was dressed as a bey and granted extraordinary privileges for any subject, except the dignity of a free man.

He didn't protest, it was not out of indifference or heroism or any desire to be a martyr. He didn't care. While serving his sentence, he had learned to be like the tide: to ebb and flow, to come and go. The things that once had not been familiar to him, that had not been his, had now become his life. His involvement with celebrations was as short as it could be: the din from the banquet and the sharp smell of the spices went to his head. He didn't care. He wanted to celebrate his achievement only. And the moira. The caress of the devil, the twist of fate that had brought him here. He went down to the cabins of the oarsmen, and he stopped, as he was, in front of the mirror, and he saw the traces of pain that still remained. He starred into the mirror: it was cloudy as though it had been sanded down and he thought he saw a sunset. In that exact moment as he contemplated this, Don Miguel discovered the impermanence of his pain. It wasn't nor could it be an end. It was instead a transition, a 
mutation. The pain, that very indescribable suffering, yielded the calm that eventually would oust it. And something else... Along with peace there was joy, like a school of young fish in calm waters. Time had passed since the last time, but he still remembered what joy felt like. A blue sea, motionless, resplendent sun struck Meseta. Joy was a mirage in itself. It was in search of peace but could no longer find it. Joy was made up of moments: a desert of a million grains of sand, a sea of infinite drops of water. Joy was "each" moment, "each" grain. It couldn't be still, as the ripples on the sea in the breeze and the dunes flutter in the wind. Joy was a desire that is reborn and is tense, almost a spasm, until fate, or that very desperate tension, appeases it.

The passage, the way back, was like going from one room to the next. That was joy. The discovery of the unknown, the conquest of something precarious. Every new island.

Now Don Miguel discovered his heart's deep desires. Joy was itself and the contrary, it was itself and everything else. Joy was pain.

In the following months, he again worked himself to the bone, breathing life into Ali's galley. While the captain sailed out of the port of Constantinople and plundered the Mediterranean and they made Tunis yet again the stronghold of the Barbary pirates, day and night the Spaniard was in his place.

He began to row again, with his usual pace, towards new goals. Everything had changed. Without the stress of always seeking somewhere and without the preoccupation to attain something, his frantic race became his freedom.

He left the base and returned many a time, with ships laden with prey and treasure or broken and shattered by collisions or storms. He went down to the ports and agreed to be auctioned off with the slaves. His wounds now caught the light. 
He left and came back many times. Overtime, without notice, he had learned the meaning of redemption and bared the fruits of his labour. One fine day, at the port in Algiers, his stump greeted the sun. 


\section{Another Sea*}

Hay no otros paraísos que los paraísos perdidos. ${ }^{2}$

-J.L. Borges

I.

"The less romantic say that the sea is the same everywhere. The immense sea with hundreds of names and just one body of water. While everything else changes, they say that the sea always stays the same, each day miraculously rejuvenated by the grace of the morning sun."

"Maybe it is true. After all, how many times have I cursed at that identical sea, that couldn't decide if it wanted to spit up the edge of the earth... But I swear, nowhere else have I heard the thunder of the Rio de la Plata when it meets the ocean. The impact of the current when it shatters on the waves, taller than houses, raising a haze and a ton of foam."

* Dedicated to my grandfather, to those who have crossed the Ocean, to their Americas.

As the man returned home, that was roughly what he thought. He went up the stairs to reach the entrance of the upper floor leaning on the stone handrail while he searched for his house keys. He should have been very sad or very happy: he had just finished telling the story of his life for the hundredth time. Before opening the door, he paused, as if he had forgotten something. He looked down at the ground floor, near the entrance of the staircase and gazed

\footnotetext{
${ }^{2}$ There are no paradises other than lost paradises. (Posesión del ayer, J. L. Borges)
} 
through the branches of the pergola. He stayed there a minute waiting for a noise, then he settled for the silence.

II.

On the ground floor, near the stone staircase, there was a door, just like in other fishermen's houses. The fishermen would open the door to cover their boats on days when the bad weather persisted, or when they needed some repairs. His door was always closed, and inside there was a boat, a light, swift boat with rotting planks. It was beautiful, more so than all the others...

One day the man decided he would no longer go out to sea: he dragged the boat inside his caulking workshop, barred the door and left it to rot. One day he just decided that he had lived enough and didn't want anything else in his life. He would simply retell his life up to that point, to whoever would listen.

III.

When he wasn't amongst people, telling his story, he would repeat the same exact routine every day. In the morning he would go to the port, down to the end of the pier to look out at the sea, or he would walk up and down the beach. In the afternoon, after lunch, he would sit under the pergola counting time. Until the sunset took him by surprise, or the water glistening in the twilight or the sudden silence of the evening. At that point the man knew he had earned another day.

By the grace of God, it was so.

It was hard to be certain of the old man's age. Some said he was seventy, others seventy-five. Yet he didn't look that old. 
He was still healthy, strong and energetic. He made sure he kept his youthful attitude. In the warm weather he would walk along the beach without a top, skipping stones on the water, watching as they bounced along the sea.

He had begun to think about death, but it was a distant thought. Death wasn't something that came up in his conversations.

I.

The next day the man got up early and spent his morning walking about the village spreading the word amongst his 'friends': whoever wanted to hear his story today should come to his house an hour before sunset.

His house was easy to find as it was the closest to the sea. The beams that held up the pergola were practically in the sand.

The house dated back to his father's time and was relatively new: the oldest houses were hundreds of years old. The man had bought it after he came back from America. He had redone the hardwood floors and the ceiling beams. He had added one other thing. On the roof there was a tall pole with a flag always blowing in the wind.

He hadn't been born in this house, nevertheless he cherished it as if it were the most beautiful place in the world. Because there under the shade of the pergola, he had lived the best years of his life, tying up garlands of salted anchovies and polishing shells.

But this was another story, one that the old man did not like to tell... 
I.

An hour after sunset the man smoked his pipe filled with American tobacco. He waited for his friends with the absolute certainty that they were coming.

He was clever, even if he didn't show it, he knew how to capture their curiosity.

He attracted them like a bunch of novices, unrolling maps and ocean charts of ancient sea captains. Mesmerised, in his face they read traces of things they could not even dream of knowing. Travelling in the crow's nests, trying to dodge the sea spray and the splash from the whales' tails, they waited a long time for a fleeting miracle.

For at times the old man's eyes flashed in the candlelight and someone could see a keel shine forth...

They say that he had conquered the waves and his harpoon could bend the wind. That he still shuddered under the smoking stormy sky. That the waves then turned to chase him...

He lived in the belly of a ship hauled ashore. Alone, like few things are; a submerged anchor, the light from a boat out on the sea.

II.

An hour after sunset, the lawyer Civardi, the doctor, the schoolteacher, a throng of more-orless young fishermen arrived and a few women also came. The boys came as well, and one in particular who had fire in his hands.

The night before there had been a movie showing in the town and they still longed for an adventure... 
During the summer the films would come from a town nearby, every Sunday. Two brothers with thin moustaches acting like artists brought the films. They would place the projector in front of the church and roll the screen, a sort of thin sheet, down over the facade. Then everyone would bring their chair and find themselves a place in the square. This created a disorganized audience divided into two wings on either side of the projector.

Each person usually had to pay a few coins to watch the show, unless it was on the patron saint's day or on a few other religious occasions; then the priest paid for it with the collections. In these cases, the films usually had a religious theme: films about miracles, the lives of saints or appearances of Our Lady. The evening before they had shown The Burmese Harp. Some had laughed, some had cried; everyone, with no exception had been left with their mouths wide open in amazement. This always happened: cinema was meant to amaze. At the end they all went home with their hearts full of wonder, and hardly anyone truly believed they knew anything about the world.

The old man's tales were different. In this case each person saw what they wanted to see, with their imagination. Everyone paid attention to the words that were coming out of his mouth. His stories were about his life and as for what he talked about: he talked about the world.

I.

The old man had organized his guests to sit under the pergola and he sat on his chosen rock, one of those talking rocks that had been around a lot longer than him. He wanted to look at each and every one of them, to make sure that they were ready to understand...

"Tell us about America, old man..." 
Long before, the man had refused any kind of formal address, which the villagers used as a sign of respect, and he wasn't ashamed to be called old man. For him it was a title of honour just like Sir or Don but better, because it meant that he had lived.

"Tell us about America, old man..."

The old man began to speak in a slow and evocative voice.

II.

It was not the first time that the guests had heard his story. But his story was always different, it was nurtured by the moonlight, by the dense shadows in the thick of the olive trees, and by the deep blue that envelops every summer night. And above all, it was nurtured by their own thoughts and dreams. So they could be sure that even this time they would hear a new story.

"I left in 1914, in the month of May, on a steam liner bound for Montevideo. I was 26 years old and had no idea of what I was going to do. Back here there was famine, while down there, they said, life was good and those that had left didn't want to come back."

"The journey took three weeks, and it could have ended badly... The steam liner was equipped to have one thousand passengers at a time, and yet on board there were at least one thousand five hundred. At one point they ran out of water, and we had to buy bottles of mineral water to wash our face. Once we arrived in Montevideo, the pier where we were meant to disembark was still under construction, so we sailed for another night to get to a port further north and returning to Montevideo by coach. We were lucky the weather had been favourable during our journey, navigating an always flat sea - calm and harmless".

A young woman, perhaps a fisherman's wife, gave everyone her explanation:

"The Madonna definitely had something to do with it. The Madonna of the Assumption, protects us all..." 
The old man, he just smiled. Throughout his life he had always defied the signs in the sky and he made fun of blind devotion. And yet every evening he would recite a curious prayer, asking the Evangelist Saints to grant him a peaceful sleep.

I.

"When I arrived I didn't know a single word of Spanish and I had enough money to live for maybe a week or so in the most run down place you could imagine. But this was the last of my worries: I was expecting more from America than just the money to lead a decent life."

In the beginning I sorted out a room in the Atracadero owned by Don Manoel Iriarte, an old boarding house in barrio portuario, and the very next day I tagged along with a group of newcomers who were going to the port... When I went looking for a job, I immediately went to the port, without considering anywhere else... Before I left, I had always been a sailor, in the army I'd learnt how to read a compass, wire a telegram, track a course and how to read the winds. I was sure that I would find something”.

"The port in Montevideo was near the mouth of the Rio della Plata, just outside the city. It was tucked away in a little inlet, sheltered from the river's whirling current and the Oceans attack. To get there, you had to cross a long strip of sand formed out of river debris and dotted with junk and old boat hulls.

The beach was covered with a sort of black sand, which wasn't so much sand but a slimy dangerous mud. Once a sailor who had ventured to where it was most slippery sank waist deep and three volunteers, as huge as oxen, were needed to pull him out." 
"I never counted how many docks there were in the port in Montevideo. But there were certainly more than was easy to count. The sailors wandered up and down the docks continuously looking for the boat they were supposed to embark on, while the captains scanned over the lines of men in front of each boat ready to leave.

I thought that amongst these crews of lowlifes and scoundrels, I would have easily found a job. Quickly I realized just how mistaken I had been..."

"At a first glance I always made a good impression: I was strong, put together, even distinguished, someone who seemed trustworthy; but I didn't speak a word of Spanish, and nobody needed a marinero sin palabras. So, for more than a month I was left to aimlessly wander about the docks. At night when even the last boat had left and all business was done, and I remained on land, I would go to the end of a jetty and sit on one of the large bollards where the transatlantic liners were moored, and I would look out over the illuminated marina of Montevideo in front of me.

II.

The tidal rips scattered the rays of light from the jetty in front of the old man's house. Above them the moon appeared as a strange symbol, as an arabesque in the sky.

"Tell us about the city..."

The old man's eyes lit up and he began to speak in a different tone, picking unusual words. Words that became ever more special.

The city's white skin was not something meant for the day. In the daylight you could only see glimpses, like secret fleeting infections of the cement. The whole time it was listening and waiting for the rustle of the evening, until the sunset enveloped it all in amber. Then the veneer dissolved, and the city danced a gasp of breaths. 
"At night there was no need for the stars: with strings of pearls strung across the city... the town swayed under them like a moon peel on the ink-black sea."

He had begun to search for these words while he gazed at the spectacle of the city at night, long before he ever told his story to others, he had planned to tell it to the one person who was always in his thoughts, but no longer here.

\section{6}

I.

"And during the day? What was the city like during the day?"

"Who ever saw the city during the day? I woke before the sun rose and by the time I got back it had already set."

The old man laughed to reassure his listeners that it was just an exaggeration. When he continued his tone changed: "The alleyways were full of shops and popup stalls, and crowds of people who strolled in and out, bargaining and exchanging pesos or just aimlessly wandering to and fro...

The shopkeepers, standing in their doorways, called out to the passers-by, listing their wares and anything else they could offer. Mostly, people would be persuaded to buy something but if they said no, it was a final no and they wouldn't budge.

Some men, coming from the port or other towns, carried huge baskets of merchandise swinging from long poles they had on their shoulders. Groups of children played copying the street numbers onto the cobblestones with pieces of coal."

"It's not easy to explain Montevideo. It didn't even seem to be one single city, rather it was a mix of many cities... In the port district the houses were stacked against each other like cabins on an ocean liner and above everything rose the sound of the ships' foghorns and the cries of 
the salesmen. Then there was the presidential district, where office workers played chess in the cafes and women with their parasols strolled down the paths of the enormous park. In the park there was a stage for an orchestra which played lively music, and right in the centre of it all was the president's house."

The scene changed completely in the outskirts of the city: chimneys with plumes of smoke dominated the labourers' district, always covered by a thin film of soot, and even further out the edges of the city were dotted with ranchitos, hovels thrown together with sticks, dung and corrugated iron. They were a breeding ground for disease, lacking any human comfort; the poorest of people lived there freely, rebelling against any restrictions. From time to time the government would try to move them into more comfortable homes with bathrooms and running water, they would last a week or so at most before returning to their hovels."

The old man smiled, because back then those men had seemed wild and mad to him whereas now, he realized that all they wanted was to keep their freedom.

II.

"What sort of people lived out there?"

"Simple people. Honest people... In the poorest areas they slept with the door unlocked at night. Hard people but compassionate. Noble, like the knights of old. On the streets, the strong ones looked you straight in the eyes while the weaker lowered their gaze. The strong ones walked ahead, and the weak ones made way, trying to hide their shame. They were melancholy people, a sort of melancholy that was in their blood. But then they knew how to be happy like no-one else. They were affable people, courteous to all. Whether they knew you or not, they would greet you, and as soon as you knew them even a little, you were considered a friend and could ask any favour. 
Don Manoel Iriarte, the owner of the boarding house where I stayed, had arrived in Uruguay from Spain sixty years before and understood, to an extent, what it felt like to be a foreigner. Once I had used up the last of my savings, he allowed me credit for a whole month, until I found a position on a whaling ship out in the Ocean".

\section{7}

I.

"Now he'll talk about the Ocean..."

Someone from the audience whispered to his neighbour. Then the old man heard a voice call out.

"Now, tell us about the Ocean. Tell us how it is the most adventurous and vast and cruel of all seas..."

The old man was always amused when people spoke of the sea as if it were an armed nemesis or a loyal friend or even a capricious woman. He didn't think of the sea as a man or a woman. It wasn't male or female. The sea was a feeling. When he was young, it had been a challenge, or a feeling of peace, now that he no longer felt as strong. The sea was itself - old, selfish and gruff - its soul unfurled and free... Nor did he believe you could learn anything from the sea. In the way you can from the lives of men. Within the sea there is everything and the opposite of everything.

"A man took his sheep to graze on a mountain side and from the ridge he could see the calm, blue ocean and he thought how nice it would be to be out at sea instead of tripping and stumbling over the mountain rocks. So, he sold his sheep and bought a fishing boat. But on his first trip the sea suddenly swelled and turned against him, sinking his fishing boat. It was a miracle that he survived. He was desperate having lost everything but still he had to live 
somehow. For many months he worked for someone until he had saved enough money to buy some more sheep. Then he went back to grazing his sheep.

He returned to the same mountain ridge, and yet again he saw that same calm blue sea and the same horizon that glistened under the sun. How could it be that very same sea that had almost drowned him and destroyed his ship?

So the man decided that his incident was just the result of unfortunate series of circumstances and the sea was not to blame. And so again he sold his sheep to buy a boat and become a fisherman. For the first year, every time he went out into the open sea, it was that calm blue ocean that he'd seen from the mountain ridge. The man was successful and so he got another boat and then another and yet another until he had a whole fleet. Then one day, while out at sea, out of nowhere the ocean swelled and began to rumble, within a moment it transformed into an uncontrollable fury that wrecked the fleet. The man survived once again and he wept, once more he found himself with nothing and no idea where to start again.

He went back to that same mountain ridge, alone, and he saw that the sea was still calm, blue and deceitful. He looked at it with the air of a man who had finally learnt his lesson and he said: Rock as much as you like, I'm staying put up here."

II.

"And so, what was the Ocean like?"

"It has hundreds of faces and you never knew which one is real. It was beautiful under the sun, with that bright blue colour that shines; too beautiful to be true... in fact it wasn't like that. The real Ocean perhaps appeared in the moment before a storm. When everything was in that false calm, when something terrible was about to happen..."

The old man was now starting to confuse the past with the present. 
He had never feared the Ocean when he was out there. Even if the Ocean had taken away many of his companions, valiant sailors who'd scorned danger and skilled navigators in any conditions. He was already old and had been living in this village for some time, when he first became fearful of the sea. It happened one night, when the sea howled and crashed onto the beach and tentacles of water splashed on the pergola just a few metres in front of his house. He was inside, sheltered, he had his crucifix and an amulet given to him by an Indian from Paraná. But he was alone, without the only thing he had chosen to think about.... There was nothing left that he must do, no longer anything he had to survive for.

I.

Out at sea a light travelled up and down the stretch of coast in front of the old man's house. Most likely it was a boat searching for octopuses in the deepest part of the cove.

From a distance the boat's light swelled swallowing the oars, hull and the kneel. Making the boat seem as if it were nothing more than a light, gliding over the water.

"The whalers in the Atlantic Ocean had been following the same routes for centuries...We travelled around Patagonia, through the Falkland Islands, South Georgia Island and Tristan da Cunha, sometimes we pushed further north to hunt Sperm Whales in the warmer waters.

Whales tended to stay in groups of twenty or thirty and so they were practically unassailable. To hit one in the group would provoke all the others.

Because of this we aimed for those that lingered behind - the youngest and the weakest - or we tried to detach one from the end of the group. Once we had isolated the prey, the boat followed it closely, waiting for the right moment when the harpoonist would launch his attack. 
The man behind the harpoon cannon did not have many shots available: It was ideal if he could hit the spot on his first go. Every failure would increase the prey's chance of survival; but as soon as it was hooked, the whale's fate was sealed. The tip of the harpoon exploded in its flesh causing many painful wounds. A bellow and then a jolt, that shook the ship like an earthquake, this was the animal's final resistance. Then the whale slipped away into a hopeless agony.

The hunting days were a frantic chase, filled with the prey's deafening bellows, the rumble of its great blood, with the torment of its never-ending life... At night, everyone slept in dread of the huge body hanging from a winch at the stern, in case it would make a sudden movement or miraculously wake. So, in turn, groups of two or three sailors would stand guard out on the bridge, under the southern winter's night sky."

"I started out as an assistant. I would stab the harpoon into the whale's flesh once it had been hooked and it was close enough to the boat. One day the harpooner got injured during an operation and I, among all the aspiring substitutes, had the most accurate shot. From that day on, no one could tear me away from the harpoon cannon".

II.

There was nothing left of that past life in the old man, and many people were amazed at how he managed to live now.

"But even then, it was not only adventure... rather, it was adventure hidden amongst peaceful and monotonous things. It was long waits, deep sleep, daydreams on the horizon and discussions with ghosts..."

The young men looked at him with their eyes wide open and shiny with fever.

They were fine, they weren't suffering from anything.

They suffered from nothing. 
Under the pergola the old man taught them how to live with nothing. Of course, it was easier for him, because he had seen the world...

"It is enough to remember the things we have all learnt since the beginning. To fear the night and be overcome by sleep, to find shelter from the rain, to smile at the sun, to wipe the dust off old memories and breathe again some air from the good old days... The simplest things are the most important things".

The fact that he himself didn't always follow these rules didn't matter. He was an odd old man, and he enjoyed walking under the rain.

I.

When the evening became humid the guests were invited to move inside the house. The old man sat them down comfortably in the largest room and let them look around before he continued telling his story.

He had an extensive collection of shells displayed on the dining table, the desk and a chest of draws with a mirror hung above. Valves and spirals, murices and conches, a huge Nautilus and a rare Cymbiola, beautifully displayed. He had shells from Antarctica and the Tropics that left the bare furniture mottled with various colours: bright reds, amber yellows and iridescent blues. He still had hundreds of them, but always less... because every night he would pick up a few, empty and shiny, and throw them back into the sea.

"After two years whaling, I was tired, so I returned to the port to try my hand at something else. 
Unlike when I first arrived, in the two years sailing the Ocean I had learnt sailors' Spanish and I'd earnt myself a reputation as an experienced and prudent sailor. That was how I found myself the captain of a cargo ship on the Rio Uruguay.

At the port they were looking for someone who could read, write, steer a boat and understand the winds. But most of all they had to be able to read and write... It was a government job, and I would be in charge of an old merchant cutter ship with fifteen men on board, including myself. We had to load provisions and other goods in Montevideo and transport them to the villages further inland."

The ship had one cabin for the captain, with an uncomfortable hard wooden bed that made him long for his sack - a mattress filled with corn husks that he slept on at home. As the captain he had the right to at least one meal a day: One thing the man didn't miss was the day's living in the village with meager meals or fasting. "And now, tell us, what was the boat called? It must have had a name..."

The old man rubbed his forehead putting his hand on his temple. He tried again and again but couldn't remember; after a while he gave up. He shrugged spreading his arms wide and gave an embarrassed smile.

It was these moments that made him feel old.

II.

First, we went up the Rio della Plata river until we reached Carmelo and soon afterwards, we followed the bends of the Rio Uruguay. From that point on we began to do the deliveries... As soon as we arrived, we began unloading the goods onto a couple of lifeboats and then we took them ashore; or the village chiefs would come on board and put the provisions in their long and thin canoe-like boats. 
Sometimes we would stop in a village for the night and party with the townspeople. But often they were cold and suspicious towards us. Everyone apart from the village chiefs, only spoke in a mysterious language. My ship-mates called it 'charrua'."

"After we passed Paysandù the vegetation along the banks became a lot thicker and we entered the most ancient and wildest part of Uruguay. There, amidst the plains of untouched forest and the half-naked indigenous tribes, we felt like the first men on Earth."

At the back of his house the old man had created a tropical garden. The oldest plants, he had brought back from the Americas and many of those were from the banks of the Rio Uruguay. Mango trees, palms and avocados grew haphazardly, more or less adapted to the temperate climate and salty sea air in the village.

III.

"We made two trips a year there, one at the end of September and the other at the beginning of January, when the weather was more favourable. Going back up the Rio Uruguay could take months and it was anything but easy.

The river was scattered with whirlpools, eddies and shallows. Often the reverse current would steer us towards the bank, pushing the boat into the vegetation: it would take days to disentangle the crow's nests and repair the sails. One time the ship got stuck on a bank of sand and we stayed there for two weeks, held captive on the boat, waiting for the rain to raise the water level again.

But the high risks brought a high reward, at least for the captain. After three years I had earned enough to return home."

"So old man, in the end you made a fortune...". 
"Fortune? Who can say...? I did what I could. Many of those who were with me did more, some less... While others made their fortune staying here at home. But I got to see America, and that was my real fortune."

"So why did you leave?". Everyone looked at the new fisherman, to see what careless person had asked that question.

I.

"For her". The old man didn't need to say anything else; his audience already knew this part of the story.

She was his wife: she hadn't been the most beautiful or more tenacious than other women, but she had a gift to make people love her... When she was young, he had been in love with her and so had all the young men in the village, but he had the gift to make her happy. Before he left, he promised to marry her when he returned and then one day, he came back from America to marry her. Since she had died the old man had been in mourning and never gone out to sea again. The frightful strength he needed to resist that desire was enough to cope with the pain of missing her.

II.

To leave America for a woman: that's what the old man had done after all. Amongst the infinite possibilities, he chose just one, to keep a promise...

“Don't lie, don't stray, remain loyal, and keep promises, these are life's commandments. If you break them there is no punishment, no fire from the heavens. You simply lose the pleasure of living". 
The old man said nothing more. His eyes flew to the edge of the night and the silence and never returned, that time.

He hadn't been a saint and he had left behind a son in America. Or so the villagers believed... For many years, every month, he wrote a letter and sent it to a mysterious address in Montevideo; the letters were addressed to a certain Pedro and the old man spoke softly to him, as if he were an old friend or indeed a son.

To start with, he asked Civardi, the lawyer, to correct his mistakes. Until the lawyer told him that he no longer needed correcting, as he had become a better writer than him.

III.

Those strange letters, the garden filled with tropical plants and the pleasure of telling his story were the old man's last tie to America.

When the boys asked him, if he loved it so much, why he had never gone back, the old man said that he wouldn't be able to find the place, to see the melancholy Montevideo again, the port with a hundred docks and the Rio della Plata. And he always added that no one could help him find that place.

But he was a strange old man and maybe he lied.

When they would bring him a map with the place clearly marked on it as well as the ship routes to get there over the sea, he shook his head and said that the place where he had lived was somewhere else, in another sea.

11

The next day the old man continued to do what he always did. In the morning he walked along the beach and after lunch he sat himself under the shade of the pergola and counted time. 
Behind his back, shrouded by the pergola, the boys spied on him. And one of them wrote a few words down every now and then:

Summer pours like a serum and the old man

smells the wind.

Time is sweetly lost

in circles,

peace amongst the lingering battles.

The old man has a dull shine of fish scales,

he chews intently, he dozes off

then opens two slits into the evening

that slips away

rattling and ringing. 


\section{In Faith, Ahab}

An earlier version of this story has been published in the Journal of Italian Translation, Volume XIII, Number 1, Spring 2018.

To my element. The doubtful and deceitful sea, starting with the name. Male and female, lush and arid, marbled and mortal. And deep down, having let go of the vice of discernment and the luxury of understanding, peace.

One must sail. Live and sail. Just as, at a given moment, one must die. And it is better to die sailing.

Tomorrow I will die. I will look into the eyes of hell and I will perish amongst the coils of the devil. Or perhaps an avenging angel will hurl itself against my arrogance in order, once and for all, to punish the sins of my past. Whether it is the one thing or the other, one side of a single fate or the other, I do not know.

I do not dare.

I admit in all honesty to knowing uncertainty well. I despair of ever managing to distinguish the ocean, the vast unfolding ocean, from the calm that sighs over the Nantucket port harbour. The clouds from the sky, which is only the greatest and most crystalline of the clouds.

If you had sailed as much as I, you would understand the illusion created by plane and perspective. The tricks unveiled beyond the curve of the horizon. You would know that impulse is the enemy of straight roads and good and bad all but fade away in the fury of life.

I despise the rise and fall. I do not dare distinguish between the easy passage of fate and the effort of the creator.

But I do believe. In the temptation that eats away at me like a woodworm, in the whispering of hell, in the rustling of the fall-in a measure of damnation. I believe in regret and resilience. 
In the crooked perfection that one attains by trying, in the involuntary beauty that glorifies the obtuse necessities of nature. I believe in my enemy, in the interminable struggle with my enemy...

Tomorrow I will die. Either me or him. There's no way out. But he is a marvel, and I am only a man. The untameable Ahab. Fearless and resentful, seeking revenge. Poor pegleg, a pitiful deformed life that has escaped life. A man who fights to be worthy of killing a marvel.

So most probably I will die. Along with everything else that will be lost and that no-one will ever be able to do again. That, for the last time, I will receive from the stars which pulse and wink in the darkness, and from the moon that seems to travel between the white foamy clouds.

Firstly, I thought of the sea. Not a stormy sea though. Not like you might imagine, with towering waves and jaws wide open, the deep cathedral-like booming.

When I think of the sea it is always a summer sea. A cheerful sea. I see it as it bubbles and foams just like a vivid dream, the beating of a transparent heart.

Like a river, free to choose its own path, my thoughts return to that sea. Inevitably. Like a natural reflex. Like the cry of a new born, like the stumble of a stammer, a reaching out and a need to leave that waters know.

We call it sea... but it is the place of Scylla and Charybdis, of gorgons and sons of Triton, the image of the Leviathan which disturbs every conscience. The sea that shines, the sea that kills and resurrects, the living grave. There is nothing which is like the sea and yet everything is a metaphor of the sea. From the waves giants are born and solidify, from the backs of whales come forth the hills, from the fish mermaids are born, from uncertain transparencies, the scales of the waves, monsters and visions.

The sea is the first principle. The earth only clotted dew. The air only a rarefied liquid. The 
seasons shift like waves over a liquid universe.

In blessed moments, I seem to hear it, the sea, as the soul sinks to the perfect depth where aqueous is an omnipresent sensation. Then the return of my thought strays into an anxiety of physical return. My skin feels dry, my breathing is the asthmatic rasp of a beached whale and I dream that I return to the sea. I leave behind the onerous task of standing on two feet and I swim away with the fish and return to the amniotic belly, the bubble of prenatal peace.

Sometimes I feel as if I have never lived. Where have I been all this time? Everywhere and nowhere. In so many places, as many places as there were days, right in the middle of the ocean. Carried by mouth and by sea until I was no-one.

No-one can say they know me; no-one has looked me in the face for more than a fleeting moment before turning their eyes away. No-one knows how I am put together.

Because I do not exist, and Ahab is just a name that has been scattered over the seven seas. The symbol of a hunt that is persistent and exhaustive and predatory, like the white whale is the symbol of a marvel, a hyperbolic omen, the peal of thunder that shatters the reckless or the unfaithful.

I no longer know who I am nor where I come from.

I have chosen to be Ahab, the intrepid.

I have only confused and incoherent memories of before. Memories of a child amongst other children. Memories of a beach where we would huddle, like the discarded nets of fishermen, drunk on salt and wind. Memories of pink-orange clouds which lapped at the shores of the islands where we slept. And eyes which rose up out of the sea to watch the molten sun as it dripped on the horizon. 
Slow, like a cautious alchemist, the sunset united gold and shadow. Before there was day and night, it was a dream dreamt by seagulls hovering in the air.

I remember this, without certainty.

I was born on an island, from an island woken up to the world and once, on one sea night, my orbit brushed against the solitude of the planets and I cast my nets to catch the stars. At least once, in the immense night, I sensed the solemn movement of the turtles who hold the world on their backs and witnessed the mirage of the sun eagle.

I wanted to sail like fish want to swim, to discover how many shadows make a night and how many nights have polished the perfect face of the moon. I wanted to sail because every being follows an ancient call to find out if the pit of loneliness has a bottom and how much water it takes to fill it up.

I have seen storms and fleeing gods predicting them to time. Blue trails tearing open like transcendent roads and the new air swelling to fill up metaphysical expanses. And afterwards, after the fury had passed, I've seen the bruised sea stagnate like a shuddering slab and the sky bend down to assist, with vague melancholy and bitter compassion. And I have seen everything that was under the sky come out of itself: souls lifted up into delirious song with the birds, the chest blossoming into flower, the horizon shaken by an immense yearning.

All this belongs to me, forever fixed in the depths of my spirit, and it shapes me into a mould of cynicism and indifference, of great passion and eternal discontent.

I cannot manage to feel lasting sentiments, God help me. For too long, my soul has been like an exhibition hall. Every feeling has taken refuge there: a moment of peace in its never-ending diaspora, like a platonic idea. It would make its home there and be true for that moment in time, that precise and fleeting alignment of stars. 
But it too would pass, like a cloud over the sun, with more or less the same weight and consistency. A shadow, distinct at first and slowly fading away, replaced by another shadow and then by yet another. A long procession of shadows...

And after all have passed through more than once, they lose all charm and warmth. The memories merge into a viscous sticky slime, all vitality lost. That arbitrary ballast, senseless and malevolent, which they call experience.

But now, for the last time, the slime has come back to the boil and started to ferment. Now I feel different. Drunk with joy and new air, already burning itself out, slowly, with each breath I take.

“Love”, I can just picture myself sneering, nostrils flared.

By now, this is what love is for me. A lightning strike or a landmine. A triumphant explosion that reveals the bottom of that rancid stagnant lake and rules for an eternal interlude before as the waters darken with fear, uncertainty and emotion - the laws of physics submerge everything once again.

Meanwhile, I love the night. And I dare you to find in the night a trace of horror: the oppressive spectre of Erebus. Myself I see nothing other than a beginning, the start of a slow atonement of the shadows.

If you had sailed, most of your life as I have, you would know how to recognize everywhere, nestled in the darkness, fragments of light. Stars, lamplights, lanterns of lanternfish. A myriad of lights which pursue one another.

They mark out signs in the emptiness, sketching the outlines of an obscure form, the shining silhouette of a monster. A white hunched mass appears every night from the abyss and its call 
draws me to it and together we set off on a fantastic and feverish journey. A blue vortex lifts us up and places us beyond the banks of the moon, where sleep barely knows the way home. One against the other, imitating the scene of the last duel.

And while we throw ourselves into the fight, even the stars glow incredulously, making themselves bigger in order to watch us. And we seem to be giants and we are but a moment. Shadows across the moon.

I do not hate the monster. In fact, I admire it, for its pure eyes, of a brazen and unconscious purity. Not like these ones, clouded by choice, free-will and possibility, and then taken back again to the light, through a malicious path, by a distorted and blinding obsession.

I revere the monster, yes. Its eyes, so blue, and its gestures, so unaware, must have been like the first living beings to ever surface the water, so graceful that heaven dared not touch them. Maddened with the desire to reach the light, they unravel undisturbed. And now they return from a time that they have stopped counting and come near the giant mass and talk to it: they bloom and whisper into its sort of ear, behind the enormous and deformed whale jaw, that it will not suffer any harm. Because any harm that might ever be cannot pass through the eye of its purity.

I do not hate the monster. I am not moved by hatred but by the reflection of something which I have seen as possible in my mind. And I liked that reflection more than anything from the first time that I saw it.

To tame a marvel. As if to capture lightning. To stop the light.

The first time I tried for fun and I failed by a trifle. And the voices encouraged me and said that I was almost there and that I would only need a little more effort. And every time less and less was needed, and the target escaped by a whisker and the defeat, of an imperceptible measure, 
demanded a rematch and evoked the mirage of a possible victory. Little by little my purpose became an obsession.

A breath of arrogance (May Judgment Day give you credit for it, good old Starbuck!)... This is at the bottom... The pit of a collapsing grave... This is Obsession.

She is a catalyst for art and inspires greatness. She is a dilated and shapeless desire. And her flipside... is nothing.

The Monster is she, and she regenerates while she consumes herself. She wants for the sake of wanting, and while wanting she devours. She is the way for us to go beyond our own flesh and the warning we cannot go beyond our flesh.

The monster is to hunt that which doesn't look for you. Urging on the sodden planks that fester in the waters of our dreams. Snarling at the Kabbalah. Gracing the funeral carriage with streamers.

The Monster is to live in defiance of the deities. And while defying, to become crazy, and while maddening to get lost.

When, like a hum in your head, again and again the same minute slice of infinity returns. When water is not enough to clean your terrified face, tempted by the abyss that is opening up more and more.

Slow, getting lost is a slow sleep. Lucid madness is an insult to yourself.

I believe that I was lost at that moment. Devoted to weaving the winds: my life made nothing in chasing after something no one can catch. 
I don't even remember how I was before. Not how, not why I stopped being that way. Decades packed into a glance, full of magic and storms, separate myself from what I was.

But tomorrow is my day. Tomorrow, if we have fought well, the poets will sing of us and we will be the two sides of the same legend, the whale and his hunter, and the name of Ahab will be remembered forever, in the seven seas, and in the vastest seas of time, beyond those.

But it will not be me.

What is left of me, beyond the insult of defeat, will be battered by the wind against some unknown shore, swollen by water like fresh seaweed, free from the weight, from the voices of victory that demands more blood, buried in the relief of not being anyone.

In the last secret meeting I spoke to my men. By candlelight, when usually I'm quiet, I told a story. I have been sad for too many days and their faces scold me. "No need to be sad," they say, "Happiness is a moment."

I welcomed the promises of preachers, but I know myself that happiness is a moment.

I pretend to not understand. I continue to stay silent while the way I am looked at changes bit by bit, slowly, until it expresses a sense of irritation concealed in words.

Not this time though. This time I surprise them. I talk.

At a guess they expect the story of a journey or a victory. Instead I tell them of one time when I had not won and I had not lost. When I had fought, though, and I was tired.

After a hunting expedition, on the sailboat deck there was no one. Everyone had gone below deck, except me that I was too tired, and they had extinguished the torches and lanterns. The only light came from the moon, intermittently, and from the edges of light-hemmed clouds. 
The waves mingled with the shadows and the shadows wrapped around the masts with the bunched up sails of the ship moored on the bottom of the sea, and the waves slowly became calm and revealed the hunched backs of the whales: at first they loomed over, hundredweights of terror, and then they almost didn't seem real. No more real than a dream.

I stayed and watched in silence, lying flat on the bridge, I don't know for how long. And yet my silence weighed nothing in the middle of that great silent apparition.

While I'm telling my tale, the crew watch me with disappointment.

It's not really what they were expecting...

Finally, someone stands up and smiles. Maybe mysteriously, he has understood

What does it matter now? Tomorrow I will die.

I can no longer go back. My men wouldn't understand and the events and the things that come to pass, intertwined with me in an inextricable tangle. I wouldn't understand it myself and my life would no longer make sense.

Tomorrow I will perish and so will my men, whom I roused from their tranquillity and brought with me to the brink of glory, prey for a dream of grandeur. The men that I betrayed and will reward with death.

Tomorrow I will die and so will my things, those things that I hoard, hidden away from the sun, and those that I possess and that are here around me, none of them excluded: I will bring all of them with me on my final journey. Precious brass and ebony will be scattered and lost, 
and a splendid sailboat the likes of which will never be seen again.

I will not leave anything else: a mass wreckage left in the wake of the obsession that was my life. And that is all.

I don't have more than that to pass on and I long to look up at the sky. My father died with his sinking ship and my father's father disappeared into the waves without a breath or a why. I know what I will find. Like those who have seen death laid down in the bed of their loved ones but every night they go to sleep without trouble.

I do not come to do anything new. Yet I must. It is me who is doing it in my turn, under the sky. And although many others before me have made this same gesture and although the object of my gaze is the same as it has been for thousands of years, I look up and I see it's full of stars. 


\section{The Mark}

He had never known what had bitten him.

Just below his neck while he was swimming. Four strokes after he should have stopped. He had not stopped.

On that final unplanned stroke, he felt a sharp pain behind his left shoulder, as though he had bumped into some sharp object, or some sort of sea creature had bitten him. He heard the crisp sound of the bite. With a couple of leg kicks he hurriedly straightened up and took a look at his shoulder. He expected to find a bleeding wound but there was nothing. He looked for scratches, for the skin to be red and welted, but nothing was there. It burned severely under the sun and that was all, time had stopped the minute before.

He was supposed to stop too, but he wanted to keep going. Just to test his strength. It was a strange morning: after last night's storm the sun was particularly bright and the wind restless. The waves were big, and the current was pulling southwest, but he felt pretty strong. He could do another four strokes.

And so, he had.

He hadn't planned to go any further and it wasn't needed. But he needed to be bitten. A bite but no biter. So that he would learn.

He quickly made his decision in a whirlwind of impulses. He looked around, trying to find the culprit. Nothing. A fish, he said to himself, something that had swum away with the current. A fish no, it couldn't be. He thought back to the moment when he dived down, when he had decided to go to his usual diving spots. Up and down in the stretch of sea near the village, untangling the nets that had been tangled in the storm and helping the fishermen rescue their nets. He was young and low in the pecking order, had to do the hard work.

The really hard work. 
If he didn't do it, he couldn't live.

He left the job half done and swam back to the shore, strong kicks propelling him. He got to the beach where he had left his things, food and some water for when he would return exhausted. The back of his shoulder was hurting. He washed it, first with saltwater and then fresh water, just as the fishermen had taught him. It began to stiffen. It was the correct way to deal with all the biting beasts from the sea and it provided a fleeting moment of relief.

The next few days he would have to skip work: fresh fish soup and a disinfectant ointment were his injury compensation. The part that had been attacked swelled up, the skin became blotchy and the pores dilated. Cuts and bruises appeared: dark marks in the shape of teeth printed on his skin like a tattoo, arranged neatly in a circle, the exact shape of the bite. Infected boils fermented all over the area that had been bitten. The ointment dried up the boils or made them burst, expelling a yellowish pus that uncovered the raw skin underneath.

The pain lasted as long as the infection, for a good two weeks, then it started to fade, and it seemed like it was disappearing. But not completely. The ointment had burnt the skin in order to heal it and had left it very sensitive to saltwater and sunlight: That is, the elements he was exposed to everyday.

He couldn't swim or straighten his arm or rotate it, without feeling a sharp pain at the base of the neck. He could no longer go shirtless on the fishing boats without a damp shirt to cover the mark.

The wound had not only penetrated the skin but the connective tissue as well. It was tangled with the flesh. Even after the skin had recovered, what ought to be dark teeth marks remained. A symbol of a non-human language. The mark of something that had touched him.

It seemed as if pain continued to talk to him through those signs when he couldn't help but feel it. When he focused all his attention on it, he could even hear a rustling. 
The pain was like a skilled boxer, it would hit him and then retreat, tormenting without driving him mad. Each time he would learn the lesson, until he forgot what life was like before this thing had become a part of him.

He cursed it and he tried to find a reason and then he gave up.

The pain ate away at his nerves and his happiness. He still managed to live till he was a very old man, but it never left him. He never found out what had bitten him. He told people that it was a monster. The unknown. Fate. The kerke. A small blue shark. The gnawing of his conscience. A divine punishment. The devil's tail. Or nothing.

Maybe he'd been born with it, and he would die with it. 


\section{The Roots of the Sea}

When I looked around

the world couldn't be found

just me by the sea

(The Ocean, U2)
It's these little things, they can pull you under

Live your life filled with joy and wonder

I always knew this altogether thunder

was lost in our little lives

(Sweetness follows, REM)

We were strong.

We had an incredible strength.

Every sunny day we would bind books and then bike, lunch caked in our bellies, to Roberto's house, quite far out of town.

Otherwise we would wait till we saw his silhouette by the roundabout, hands in our pockets, kicking stones. We would greet each other, with knowing looks and slaps on the back, then check every piece of our gear. Then all four of us went down to the sea following the rocky ridge as far as the cove of the dead.

We had fallen in love with that name a long time ago...

The elders in each family had passed down the tale of a shipwreck: a freight ship that had tried to escape the storm and instead found a rock hidden by the night. Ghosts of the dead wandered about for years, fleeting shadows on the water's surface; until a funeral held at sea and a cross placed atop the cursed rock banished them.

The place had nothing sinister about it. A crack carved into the side of the mountain. Just a dent across the sheer drop of the cliff. The rock with the cross was a sombre spur a few metres out from the beach. 
At the bottom and almost out of sight, the gorge opened up into a stony beach. Narrow and encased by the rocks. Too narrow and closed-in for the needs of the fishermen, it became the territory of the seagulls and the lonely.

Sometimes even we didn't go down there. We would perch ourselves up on the spot with the best view out to the horizon. We would look out to the edges of our world, the only possible world. In the haze of the sun it appeared as a great glow, still shining: day after day we waited to catch sight of something.

On and off we talked, and in between long moments went by waiting for our words to take off. Our words had a scent and a weight to them.

Our last school year was coming to an end and choices awaited us, sword in hand. We knew everything, but nobody seemed to care. We carried on doing the things we had always done, pretending that it would last forever. Yet either our hurry or the unusual care of our actions indicated that they would come to an end. Our need to shape time, to transform each moment into an intense experience or a special ritual, showed it all the more. That morning Roberto arrived early and all out of breath, explaining his idea in a rush. "Today let's go to the cove and stay all night."

Confused, we looked at each other and wondered if he was joking.... Roberto was always joking. Without malice and with complete disregard for the consequences. We should have never had to see him desperate, one September day when a wall of clouds loomed over the sea and the storm refused to come in. He was in a room with his dead father, he stared at the ground not knowing what to do. After some time, we found the courage to approach him and say how sorry we were. He shrugged his shoulders and said nothing. 
After a few days he laughed again, but never like before. Something had been lost. His infectious power of not giving a toss.

That morning at the roundabout he saw that we didn't believe him. So, he threw down a crumpled tent and carried on: "It was my dad's, from when he fought in Africa. It's a bit battered but big and sturdy. We'll put it up at the cove and will camp there for the night. We've never been to the cove at night."

We looked at each other, still puzzled: a night at the sea was a serious affair, for fishermen. But we had never done it and certainly we wouldn't be doing it later.

In the end Arturo nodded in approval and so it was decided. If Arturo agreed, then it was sensible enough to try.

Arturo was the leader. He hadn't done anything to become so, he just was. He understood the role and took it seriously: he forgave the others but was ruthless towards himself; he could not afford to be uncertain; he always needed to have the answer ready. When the others teased him to test his ability, I hated him because of that immeasurable challenge with himself.

The bustle of the commuter bus made the decision final: first we took the road up to the school, before it became too crowded, wary and excited conspirators.

Roberto trudged along, his bike beside him, as he explained the rest of the plan.

"Tell your parents you are studying late at mine tonight and I said for you to stay. I'll say that I am staying at one of yours in town.... We'll meet at the usual time by the roundabout".

At home, my mum was setting the table for lunch. She told me I could go but I knew that she wouldn't sleep that night. My dad was in his shop doing the monthly accounts and wouldn't be home for lunch. 
I sighed a breath of relief: he didn't approve of me spending the night out. He couldn't deal with my mother's anxiety and felt like I was always inconveniencing him. Usually he made some sort of protest, but even without speaking I could sense his irritation. He couldn't be persuaded: where could you sleep better than at home?

My father was a strict man, but he was a good honest man. A hard worker with broad shoulders and little sense of wonder.

I didn't blame him: wonder is a luxury for those who can afford it. He was born poor. His father ploughed the land and feared the sea.

He didn't like the sea either. He called it a "bastard".

After the war he had gone to America, like many in their town: he borrowed the money for the trip and crossed the ocean with a cousin. He'd missed my birth and returned home when I was already three.

In America he traded in fabrics and earned well... Before leaving he paid off his debts and sent my mother some money and a letter. Once he returned, with the rest of the money he bought some land and opened a shop.

He sold a bit of everything: from dolls to fishermen's tools. As well as books about the sea, which appealed to foreigners.

He also wrote letters for the illiterate, accepting what they could give him in return. In spite of all, that was probably the most fruitful part of his job...

He had wanted me to study hard and write well, to learn more things than he could have ever leaned. Recently we had moved into a new house, a big solitary villa in the new part of the town. A weeping willow adorned the courtyard entrance. The floors in the main rooms were covered with rugs and the heavy drapery recreated the dim light of colonial houses. 
My father still had a business in America with his cousin that had stayed over there. But he didn't like running his business from afar. So the following winter he would go overseas to collect his money and sell his share.

In his absence I would take care of the shop and help out my mother who still had my little brother to look after. It was decided that I would interrupt my studies, at least for the moment.

"It's not as if they will be losing a great mind". My father smiled and put an end to the family meeting. I bowed my head to his rude and piercing sarcasm, while I said to myself "touché".

That day, those of us from town arrived on time and Roberto joined us shortly after. On the luggage rack he had the tent, a sweater for the evening and some provisions. In a bag attached to the handlebars, there were three bottles of wine wrapped up in cloth.

Each one of us had brought a bag with the necessities.

It was early afternoon when we took the road down to the marina, lunch caked in our bellies. Luckily, we just missed bumping into crazy Gino, who wandered around, talking about death with a lost look in his eyes.

Some days we dodged him, others we tried to cheer him up. He had a look of painful resignation on his face and his defence was that he was not to blame. He just had to get used to the idea...

At that time of the day, the port was coming back to life. My father was still doing the accounts with the door of the shop half closed. The other men had gone back to work. They trod their paths with confidence, continuing on their course like large sea birds. Their firm wings did not waver.

As I watched them, I suffered more than ever with the weight of my own doubts. 
The boat keeper was wandering about the dock. From far off we saw him raise his plucked head and follow us with a mocking sneer.

When we approached, he greeted us frankly, man to man. We noticed that he whistled while breathing.

He held back and we realized that instead he wanted to talk.

"How is it going today, old man?" Arturo started.

The old man puffed his bird-like chest and widened his blue eyes: "There's always something to do with some damn wreck. Scraping the keel, restoring the oarlocks, putting in the tows and coating with tar: a man alone is not enough... Today I put one in water that didn't want to stay afloat”.

“Seh... you've been hanging about all day, haven't you"? Luca enjoyed teasing him. There was nothing going on around him and we only glanced at him: we had no interest in grasping the details of his arcane job.

The old man's tone was reprimanding: "Only God knows that I always do more than I should. If it wasn't for me, they wouldn't be able to sail off and catch their beautiful fish! It's easy to sleep soundly when somebody else is out here at night watching the boats. But what do they know? They don't even say thank you. They sleep...

I've been a fisherman too. And I remember the noise of the waves hitting the hull, even if it has been a while since I heard it last. And on the other hand, have they ever heard the soft clash, the slow roll of the planks moored fast? It's because someone counts the boats and secures the knots and keeps the distances and pays attention to the tides. That's how everything stays in its place. But what do they know... they just sleep". In fact there was no real danger for the boats. No one would have dared to touch them in a poor fishing village, where everybody knew each other. But the old man needed to feel important. Especially since he could no longer venture out on the high sea. 
Luca was about to reply but I signalled to him to leave the old man alone. The old man whistled, stumbling back to his seat.

Close to where the boats were hauled ashore, after they had been coated with tar, the boat's prow rose from the water.

We walked on past the pier. Because we had our bags we took the track along the shore to reach the cove. We walked across the rocks, with careful, measured steps so as not to slip, it felt like with each step we were making some final decision. Later the tide would flood the protruding rocks and block our way back.

We crossed the beach where the fishermen were crouched down mending their nets... They looked up for a moment as they noticed us going by. A light glinted in the depths of their intense and tiny eyes.

Meeting them face to face in the marina was always unsettling. They showed signs of battle and a wild heart. Their burnt skin revealed the open flesh of recent wounds and their toenails, which had broken off on the rocks, grew back rough and chipped.

But there was a certain beauty to them too. Their arms were lean and muscular, their shoulders shone like nuggets of gold under the sun.

I felt I owed them respect.

The land where we grew up belonged to them. To those few men and to the immensity of nature. To their bloody struggle with no resentment.

I spied on the fishermen who were busy on the beach and utterly silent. Nobody knew the game of patience better than them, no one knew so precisely the measure of the void. Luca was not interested in fishermen. He didn't like everything that taken root in our land. Instead, he liked the night. And the sea with its horizon. When he looked at it, he knew there were other places to live. 
Arturo thought differently. He would say we were lucky: our land was beautiful, and it was a wild metaphor for how one ought to live. He particularly liked the fisherman's lifestyle, which he would sum up in a few memorable accounts.

Waking up early and going about freely. Being alone with just the sea and the sky. Feeling far away from everything and not being afraid. Pushing yourself further each time and then coming back when it's time, always finding the rhythm that, stroke by stroke, would bring you home.

We arrived at the cove and it shone under the sun. The seagulls were barely visible against the pale rocks. The sound of sea smashing into the hollows of the rocks echoed. There was a crack in a rock close to the shore, a sort of fissure. If you looked closely you could see straight to the last point, where the stone tower kept watch without counting the time. We put the tent up where it would be best protected on the beach, then we sat in a circle with our books open.

"Frigora iam Zephiri minuunt, annoque peracto..."

Ovid talked of his exile among the Geti and we were supposed to understand what exactly he was trying to say.

As usual Arturo did the work. Every once in a while, Luca would offer his opinion. Roberto and I waited till the incomprehensible became a little more obvious.

The sun was still high in the sky above the cove, but it was no longer blinding. Slowly it began to cool down against the languid afternoon sky.

In town, at that hour the 'foreigner' would come out on to his balcony and unfold his spyglass to watch his fleet leave. The boats were red, the colour of unpainted lead, and they fished for anchovies half a day's sailing away. 
The foreigner would lose sight of them long after we did, he sent his blessings. Afterwards he would go back inside, waiting for his fleet to return.

With our imagination we would follow him to secret places we were not allowed. Weaving together theories and tales from a few witnesses, we wondered how he passed his time, what obscure tasks he set himself while he waited, he never went outside, not even for a breath of fresh air, not until it was the exact time the fleet would return home.

Unexpectedly, as I opened doors and scanned the ill lit rooms, a shadow of a low flying bird shot across the pages of my open book: the image of the foreigner that occupied my mind, vanished with the breeze.

As I came back to myself, I looked at the concentration on Arturo's face, as he read. I watched him for quite a while until he quickly lowered his eyes to the page and began to read aloud.

Arturo and Clara were no longer together. It had been a month now. They had suddenly stopped holding hands

He had told us himself. He gathered us together with some poor excuse and coughed out a few words: "Clara and I are no longer together. Don't hold it against her."

Clara was a classmate who had recently joined the class. She came from far away and she was shy and different. No one had ever noticed she was beautiful until Arturo kissed her. She had come down to the cove with us, a couple of times. She lay down by Arturo's side, perched on her elbows, her head resting on his shoulder. She would listen curiously, but she barely spoke. She loved the peaceful feeling of the cove.

Her mother was sick; some said crazy. Her father had been born in the village, but he had left when he was young, to cross the border. And now he had brought back his slim fortune... He worked two jobs to pay for a nurse that reminded him of his pain three times a day. 
Clara had grown up carefree and without malice, but there was something sad about her. Maybe that was what Arturo liked about her: she was fragile and complicated like the things he dreamt of.

There were no simple gestures between them. She hinted at tenderness and he moved in a tentative way, as if he feared making a mistake. Sometimes they looked at each other, their deep eyes meeting hurriedly. It was beautiful to watch them that way.

Arturo suddenly dropped the pen and got to his feet. Soon after Luca gave us a sheet with the finished translation.

Roberto shot me a pleased look, but I felt no satisfaction. I waited a little before I started to write it down, reluctantly. Every now and then I would lift my eyes and look around. Beyond the farthest point of the cove, a few boats were beginning to head back to the port, at great speed, as if they wished to save time. It was an odd time for boats to return at this time, they were likely to be blessed with unusual cargo or dogged with bitter misfortune.

The fishermen's white boats were the image of our dreams: as they went out to sea, making vows at sunrise, and coming back at sunset, either full to the brim or lamenting, cutting through the metallic blue of the water. In my imagination, they conjured the idea of infinite freedom, together with a sweet sense of attachment to our roots. They miraculously mixed fear and courage, the lightness of daring and the weight of living.

Without noticing, I had stopped writing.

At the water's edge, Arturo and Luca looked out to the open sea. And I thought about what makes a man a man.

I thought that some men are made to challenge the sea. Those strong enough to cross the horizon without looking back, those able to heal and to forget. Other men can watch the sea, 
maybe dream of it in all its boundless expanse. But they must stay with their feet on the ground.

They wouldn't put up with the boredom of still waters, they were after the test of starvation or being alone. They would not get to enjoy the reward: one day, on their own, to see white sandy islands and dreamy blue-green shores.

Arturo and Luca looked out at the open sea. They seemed ready to take off. I knew I would not have dared to go beyond the shoreline.

I could only pretend to keep up with them; but that day - only on that day - I joined them and together we looked off into the distance.

The outline of a fishing boat stood there balanced on the horizon.

I pointed to it and Luca squinted searching for it. He didn't have great eyesight, but he refused to wear glasses. By now he had given up on seeing details.

He would joke about his 'impressionist' sight: I thought of him as a rebel with the strange brilliance of a hero who would never win.

He soon grew tired of looking, he let out a sigh, then left as though he was keeping a secret. It was just Arturo and me as the evening carried on.

We watched the clouds become hemmed with pink and orange and then bruise to blue, while the moon left its faint stamp on the sky. The sun lay down on the horizon, melting as it sank into the water: for a while you could not distinguish the sky from the sea. The first star shone in the violet twilight sky. The others appeared gradually. They shimmered together like veins of gold, swelling and shrinking as if with each breath. They could fulfil all dreams and perhaps they too were a dream. The dream of the dark. 
It took various attempts before we managed to light a fire that lasted. A sea breeze had risen, and the air had cooled down. In the end we stuck a bundle of twigs amongst the logs so that the flames caught the harder wood as well.

The darkness roared in and the glow of the town barely lit up one corner of the night. I remembered that the water appeared to shine under the lamps on the seaside as if it were made of scales.

Arturo tried to break the silence. Every now and then he would say the name of some constellation. Then he would point it out amongst the cluster of shining spots trying to find some order.

Roberto had slipped away. Anxiously he looked around as if he were waiting for something; and the longer he waited, he became increasingly determined and desperate. I moved closer to him, but he wouldn't let me talk 'I have already decided. I'm going far away and won't come back soon. I'd just like to take something with me. Something, I don't know how to explain it, the feeling of what I have seen until now. I can't spend another day figuring it out."

I looked away. I could have told him that he was mistaken, that he would be unnecessarily alone. But I said nothing. It wouldn't be right.

Far off the last lights on the port were falling into the water. They ventured off for a while and then lost themselves in the darkness of the sea.

The stars continue to shine. Luca gazed at them. On that clear night he discovered some stars pulsing in the darkness that usually stayed hidden.

"They are all our possibilities".

He spoke quietly as if he were revealing a secret.

"There they are, not moving, waiting for someone to conquer them. Some shine for a long time, some just for one night. They too are looking at us now. The stars do not ask for 
anything, they shine... Who knows how big the night must be to contain all of them? And how big the world must be to contain the night. I am frightened of how big it must be. I fear places where I won't be able to see the stars, will they stop shining, just waiting for me? I'm frightened like someone that worries about death. It's strange... because I think about life". He finished speaking in a murmur and a thought shadowed his face: an old pain — once anger and regret — was now swaying in him, calm and immense like the sea. Arturo had listened to him carefully. In the end, as he got up, he uttered a sentence that I had read in some book: "I could be bounded in a nutshell, and count myself a king of infinite space, were it not that I have bad dreams."3

Then he headed towards the tent to fetch his sweater. Roberto and I followed him.

Luca was further off and didn't hear when we signalled for him to come. He floated amongst his thoughts like a damaged boat. Enclosed in his own elusive sadness, he remained alone, nestled in the darkness.

Inside the tent it was slightly lit by the moon.

Roberto saw the bottles of wine in a corner. He unwrapped them and then, grabbing them by the neck, lifting them in the air. The look on his face suggested something... I never drank and I didn't like it, but I could not hold myself back. One time Roberto's father had told me that you could tell a man by how much wine he can down.

It didn't take long for Roberto to get drunk. Tired out, he fell onto his back and began to roll about on the beach slurring in delirious laughter. He rolled and laughed and didn't care about where he was going.

\footnotetext{
${ }^{3}$ Hamlet II 2 [translator's note].
} 
Finally, he stopped and turned onto his side, away from the fire. He went silent and then we heard him cry. He cried softly for a long time, like a man that had quickly succumbed to wine.

Under the moonlight the tide lines quietly rolled in and out.

The night beyond was empty. An all-encompassing emptiness. Voiceless.

Silence pounded our temples. It was a deafening buzz inside your ears. Miming words but no voice... they were all prisoners.

Suddenly the words flooded out, throwing themselves at the bars and trying to escape; then begun to fade again. Until they became a monotonous hiss. An impression. Nothing.

That night nothing happened. Nothing really, the cove where you could still hear the voices of marauders and the sound of a whale was once heard.

And yet something had found us. Something that had been waiting in hiding. Something simple and terrible, that awaited darkness.

We needed to pack to keep quiet.

The day of the exams, my father eagerly waited for me outside the gates. Every summer we went to spend some time with my mother's family by another sea: we would leave that same afternoon. Walking through the courtyard I saw Arturo talking with Clara: biting back his anger he let her go. The clear sound of their parting lasted a moment.

The afternoon train arrived on time to the pleasure of my father. It came into view from behind a bend and disappeared behind another seconds later, departing with us on board.

During the trip I thought about Clara, Arturo, and the sound of the decisive moment: everything comes down to that moment, and when it does come, everything makes sense or it doesn't. 
I tried to remember Luca's words from that night, confusing them with my own sadness. He said that we don't need to build anything, that everything is already waiting for us: a vast crowd of opportunities...

We can either take them or lose them. Passing them by absentmindedly or deliberately chasing them away. Making sure they would not come back.

My sadness turned into spite.

Did I really need to feel sad for Arturo and Clara? What was I complaining about?

Deep down, I always knew. That Arturo would leave, and Clara wouldn't be able to follow him. She had no choice, none of us did. Arturo needed to leave, and I needed to stay, Luca needed to find his place. Maybe we were all mistaken.

We needed to make our mistakes.

Faultless mistakes: it's the price we have to pay to be ourselves.

My thoughts were interrupted by my father as he scolded me for thinking too much: We were halfway through the trip and I had yet to say a word...

I replied unconvincingly that he was right, but I kept on thinking. About Clara, about Arturo, about the possibilities. I carried on thinking about this for a while, then I stopped.

In front of me, my father held the little one in his arms and talked with my mother, about how comfortable the trip was, about the store's stock, about what he would find in America. Every now and then he would turn towards to window and distractedly look out and the shining sea, the organized orchards as they passed by.

Wonder belongs to those who nourish it...

Yet my father's obtuse disenchantment barely touched me. I saw him from far away, slowly becoming smaller, like the images than ran by the windows; the sky was the opposite: it seemed to always be larger and like new. 
On the train I felt what it feels like to leave somewhere. Even if it wasn't for long, even if I was to return.

The others stayed in town to pack their bags. And when it was time, they left without another thought.

By the time I got back they had already gone. Before I found out, I read it in Clara's deep eyes.

I often wonder how looking beyond the horizon changes a man's face. My father's face would have changed after he left for America. I'm sure some nights my mother looks at him without saying anything as he pensively sits there. He frowns, his eyes go far away. And for a while he harbours some mystery.

I think I know the distances of the worlds from my father's eyes. From nothing else. In the end I stayed in town... After all, working at the store was a good job: business was going well, and my parents needed help. Day after day I learnt not to think of what would have been if I had left with the others.

I never saw them again. None of them.

Apart from Clara. I see her every day. She comes in to buy gifts for her mother, she smiles and tells me all about us running away together.

Every now and then some news arrives. That Arturo will soon be a doctor, that Luca writes for a newspaper, and Roberto has become serious. Most people believe they will not come back anything soon, I too have stopped waiting for them.

I don't even know where they are.

For me they belong to distant times. That night, the memories, the silhouettes of the fishing boats. And even further away. To the nest of the stars. 
As soon as I can, I return to the cove looking for that same feeling I felt when we went down together.

Bewilderment. Oppression. The precise feeling of being out of control.

Each time they become fainter, blurry: one day they will disappear altogether.

I don't remember anything that changed after they left. The noise of the propeller is mixed with the sounds of stock moving, the rumble of summer storms on corrugated iron. It opened a new season of feeble intentions and endless expectations.

One waits for the pull on the line, to come home in the evening with fish to share, one expects something to emerge very late in the evening.

Sometimes I feel like the sea leaps over the shore and slips through the alleyways and submerges the doorsteps, the front doors, the cages that house the lanterns attached to the walls. And we live like an underwater nation. Far away from everything. Instinct keeps us in the current and we are content with the evidence of our lives.

With these people I share a simple task: to fill the void and be at peace. Nothing more. Nothing that resembles living within the all-embracing din of dreams and sometimes seeking silence under the stones.

Every morning I wake up early to see the town wrapped in fog, the hazy borders of a dawning day; I pay attention to the voices of the fishermen down at the marina, as they appear to be secretly laying out invisible threads. Then, as soon as the sun rises, I open the store.

For the entire morning, between one customer and another, I look out at the square from the front door to check the time. To watch the shape of the clouds. I wait for the still peace that happens at noon...

What happens after is written in the shivering sea, in the shadows that little by little conquer the sky. It has been called vespers, twilight or early evening, but it is always the same time. 
In the evening I follow my father who returns home full of air. We stop to smell the blooming jasmine, listening to our footsteps on the ground without saying a word. Without it being silent.

Because every time the sea's peace is muddied with voices, and so we can't tell apart the cries of the living, the litanies of the drowned, the impassive tone of things that have no soul. On the street corners the old people flash a smile. Now they call me by name, their eyes tell me that I belong here. But they quickly forget the names of those who leave, of those who come to surface answering the call of the light. Those ones temporarily break away from the dark depths and quickly go back down to sit on the roots of the sea. 


\section{The Wind Doesn't Give a Damn}

A filthy hovel. A wretched filthy hovel. For this, they had sailed, for who knows how long and in what direction, setting out from a pier on the West Side into stormy seas, against their better judgment. For this, they had braved the storm, coming out unharmed by sheer luck, and washed up on the shore of an unknown unmapped island, battered but there. For this they had tramped over hectares of damp, lush forest in the rain that never stopped.

The man led her by the hand. His arm muscles were tense and taut, as he carried the luggage and dragged her along the path that had turned into a stream. She kept tripping in her high heels, though after a while she'd stopped caring about the muddy water that drenched her evening dress.

They climbed upwards. They passed through dense forest, huge trees with twisted branches and roots pushing up out of earth. The bush, a kind of rain forest, cast a gloomy atmosphere. The dense foliage tangled above them and lower down in the shadows the undergrowth was wild and dishevelled. The din of the rain drowned out the calls and cries of animals sheltering in their dens. Coral-coloured snakes slithered coyly through the bushes.

The hovel was at the top of the hill. The tangle of the forest opened up into a clearing and there appeared a hideous shack. Half prefab and half corrugated iron, built haphazardly out of whatever rubbish was lying around. A squalid Eden in a Dantesque purgatory.

They sheltered under the bamboo and raffia awning. They looked behind them at the hill that sloped down towards the sea. The door creaked and shook as the man opened it. He went into a low-ceilinged, dimly-lit room. He smiled as he entered the room, putting the bag on the ground, and as he threw the backpack on the couch it coughed up dust. They had met the day before, at the noisy Saturday night party, the reward for an exhausting week of work at the 
bar. Jane had gone, as usual, with Maggie and Sue, or maybe just with Sue. She had drunk a little too much for her liking. She was tipsy and at a certain point she'd felt like dancing. And then on the edge of the dance floor this smooth-talking macho guy had introduced himself and she had let herself be seduced. They danced, one slow dance and two jives, and then he whispered a few bold words in her ear and she agreed to follow him to his boat. They kissed on the pier and then he took her in his arms and she thought that it would be nice to make love out at sea. She liked it and he started to talk about escaping to enchanted places while they smoked the ritual cigarette. There must have been something strong in it. He started to call her 'princess,' and then she didn't remember anything else.

When she woke up, it was daylight and they were in the middle of a storm - waves splashed over the cabin, bucketful after bucketful - and the man told her that the boat was damaged and they were forced to disembark on an island he'd been to before, somewhere he had a place they could shelter, a sort of storage hut with spare parts and tools to repair the boat.

One hour, he said, and they would arrive.

One hour, really, and they were at the destination.

Twenty-seven degrees longitude north, seventy-eight degrees latitude west. Could she still read a nautical chart?

Twenty-seven degrees latitude north, seventy-eight degrees longitude west. She saw it written on the compass attached to the ships' wheel when she woke up. Twenty-seven degrees latitude north, seventy-eight degrees longitude west. It wasn't just off the coast of New York. There was no island off the coast of New York. And it wasn't the right climate for New York. Twenty-seven degrees latitude north... It was definitely too little for an island as big as Manhattan. Maryland, perhaps, Virginia... Florida, my god, Florida! 
The climate, the rain, the hot humid air of the monsoon season: they were definitely off the coast of Florida.

How was it possible that they got there in just one night, in the few hours she had been asleep? The boat didn't seem that fast. And clearly Florida had not come to them. Unless... Two days!

The more disconcerting hypothesis was also the most plausible. The coin dropped loudly. The dawn of the next day was not that day... She had slept two entire days! It was not normal: she said it out loud as to be sure that it was a rational question. One does not sleep for two days because of a hangover or great sex.

Drugged? Sedated? How?

He had done it.

Who else?

He'd lied to her from the beginning. On the boat and then on the island and perhaps about the motives for the trip. From the moment they arrived he'd given elusive answers to each of her questions and found any excuse to delay their return.

Fruitlessly she tried to follow any plausible logic. Every moment of solitude she used to think, to put the pieces together: as more time passed, her dizziness disappeared, and her memory began to return. Still, she couldn't make sense of it all. Suddenly everything seemed out of focus, distorted, as if it were reflected in a warped mirror.

In that exact moment John appeared at the end of the path that led to the hovel. He was returning from his morning fishing expedition and had two large fish on his back.

He was happy to see her in the doorway. He hurried up the path, his muscles taut and his steps agile like a damned jungle scout. The whole scene had something primitive about it. He smiled at her. Bastard... 
He quickly understood that something was wrong. He saw her exhausted face, poisoned by thought, and her hands twisting around a broken broom. Her mouth creased as she asked bluntly:

"When are we going back?"

He put the fish on the table. He made a deep incision from the head to the tail and extracted the bowels. He didn't notice the time passing and it was as though he wanted to forget the question.

Then he spoke in his normal tone. Because he had no choice, because he could only do two things - say it or not say it - either way there were consequences.

"Not today".

"Not even today?"

"The sea is rough and the boat needs repairing. We have to wait for the waters to be calm or the waves to push the boat ashore.

Jane was spewing with hatred. He had lied to her. He reassured her and lied to her. He looked at her tenderly and lied to her.

"How long do we have to wait?"

"Bitch" thought John.

But he ended up saying "fool”.

"You fool" he said.

It was so strange that she had noticed... That they weren't off the coast of New York, where there was no island, that it wasn't the New York climate... How did she know? Why did she want to go back? 
"Do you really want to go back to the bar? To the familiar confusion of Fifth Avenue, the stink of the customers, the construction company oafs, the tie wearing posers, the dirty language and flexible working hours of the distinguished Mr Turner?”.

“Tur-ner", he repeated slowly, "a name so banal it sounds fake. Do you really want to go back to be insulted, to clean toilet floors, and then just wait for the same old parties, with the same old friends, waiting for the night, the silence and the respite, with the heat of alcohol or something else in your body, begging for a little peace?"

Jane was startled.

"How do you know all those things?"

He didn't hear her.

"Too much, too much time. It's not good to do the same thing for too long".

He had to hear her.

"How do you know all those things?"

"There's always something we don't know".

Tell me, tell me, tell me!

"How do you know all those things?".

"I have been following you. You have no idea for how long."

Jane looked at him, in shock. She started to weep.

John suddenly lost his Olympian calm. He stuttered angrily and then he snapped.

"You belong to me. You always have."

He turned to look at her, afterwards, just in time to see her face darken.

Now she stared at him with tragic eyes.

It had been pointless. He couldn't tell her, he couldn't make her understand. He had been foolish. He had hurt her. 
"I didn't mean it", he apologised.

Jane seemed to calm down for a moment but then she found the whole story all the more horrifying.

A hysterical sob burst out of her. She felt all strange and shaky inside. She couldn't manage to stop crying, crying and coughing as if she were choking to death.

"I didn't mean it". The man's hand brushed her cheek, but she pulled back, disgusted.

She had made love with this man. She had been with him, rolling together in the mud.

"I didn't mean it, really". He approached her hesitantly, almost in disbelief, more and more agitated about this unexpected reaction which he couldn't control.

She spat at him.

The man staggered back, a look of irrational fear in his eyes. He looked at his hand as if it were being eroded by poison.

The next moment, he was on her with his hands around her neck. He throttled her and threw her onto the table.

Jane's body trembled uncontrollably. Her legs thrashed about in the air. Her senses, her will and her conscience were numb. Curled up. Coiled up to withstand the sudden impact of an explosion.

An acrid tang of blood, internally. She could taste the bitterness in her mouth. It violated her strong determination to stay oblivious. Her head spun with a burning ache from the blows.

The door latch closed noisily. Behind the door, a hand turned several times and then pulled something out of the lock. Meticulous piece of work, and now the author was bringing down the curtain. As her torpor faded, Jane saw it all. 
She was in the centre of a small room, tied to an ugly wicker chair and a frayed piece of cord cut into her thigh. She was gagged, a rag shoved in her mouth and tied at her nape in a loose knot. She could grunt but not shout. Could she move? She tried to shift her weight to one side, to the other and then back, not caring if she fell and hurt herself. But the chair didn't move, as if it were glued or nailed to the floorboards.

She felt some swelling on one side of her face. The blood throbbed from the recent trauma. She was going to have a black eye.

With the other eye she scanned all corners of the room, in an effort to orient herself. A small window, fogged up, filtered a weak ray of grey tinged light. A worn brass basin dripped water. A hunter's cap hung from a hook on the wall. Papers and maps were littered across a shabby table. A shovel, a bucket and a half rusted billhook were piled in one corner. Behind her back and out of sight, a small part of the room remained inaccessible. There was also something hanging on the wall: if she twisted her neck as far as she could, she got glimpses of the edges of it. A painting, or something like that; she wasn't able to see it but something about it unsettled her.

For a while, she managed to focus on herself and the space that she was in. No noises were coming from the other room.

Then she could hear John again. Starting up a conversion with himself.

“I can't do anything about it". He muttered.

"That's how things go".

"I can't do anything about it".

A calm lullaby. Frightening.

He was cooking something. 
The fire was glowing. John sat next to the fire, his head in his hands. She could hear him wheezing, she could almost see him. It hadn't passed yet: he could topple back into it, any moment. She mustn't give in, she mustn't irritate him, not now. She narrowed her eyes and bit the rag and clenched her fists behind the back of the chair: anything to contain herself. She cried silently.

There, she heard him coming. She had to calm herself down.

She saw the light under the door darken and the lock opened noisily.

He came to bring her food two times a day. He would remove the rag and feed her. She just had to keep her mouth open and let the food go down her throat. She had refused the first few days but then hunger had taken over. She would keep her mouth open and swallowed the morsels of food without tasting them. Tiredness made everything easier.

Apart from meals, John kept his distance, as if he were embarrassed: the sight of her as a prisoner made him uncomfortable. He stayed outside or in the other room to do noisy tasks and impose his presence from afar. In the morning he went fishing, at midday he cooked and the rest of the time he kept fiddling with his carpentry tools. He usually left the door ajar, and poked his head inside to check on her three or four times a day.

But there was no need. Even though she was imprisoned, Jane always behaved.

She waited for the silence of the night: only at night did she get a break. The racket from the next room turned into an incessant light that seeped in under the door. John, the macho guy, slept with the lights on. And more often he wouldn't sleep. He hadn't slept since their quarrel. She didn't sleep either. She didn't want to sleep. She dreaded the idea of losing something else during the night. 
She entertained any thought to keep herself awake, to kill what seemed a timeless time, to wade through hour after hour... A long, dream-like journey.

John arrived early in the morning, earlier than usual, and she was not at all calm. He walked close to her. Her mouth was dry, and her heart pounded.

He tickled her chin, like you do to a child, and Jane felt vaguely nauseous. He tried to humour her by talking to her the way one would talk to a child.

"Do you still think about it?"

He stroked her head.

"I don't. I don't remember what I said".

He laughed as if she joked along.

"You took it the wrong way... Don't be unreasonable... You and me in this place. From now on it will be beautiful". He said this overly joyful.

He lent in as if to kiss her.

Jane turned her face away and lent her head back. She instantly regretted it but she was surprised that John didn't seem annoyed.

"Are you angry?"

She shook her head.

"Really you're not angry?"

Jane looked down. He got down to her eye level, and looked up at her.

"What else do you think I could have done?"

Jane didn't answer.

"It was a mistake, what else could I have done?"

She looked at him numbly.

"Is it not so?" 
"Yes". She answered blankly.

It was hot. John opened the window on one side of the room and fixed it open with a hook in the window sill. The sun was beating down. Luckily the light filtered through the dense foliage of the trees surrounding the shack.

"Forget what I said". He came over to her again. But not as close this time. "I'm sorry". He was pretty much kneeling in front of her. He seemed disheartened.

"I love you". He was trying to tell her something, but he feared she would not understand.

Despite being tied up, Jane shuddered.

"How dare you, you evil bastard... You call this love?" She wished she could yell this in his face.

"OK”, she murmured.

"Do you understand?"

He smiled at her. She smiled too.

"Love harbours all sins".

He smiled at her again. She did not.

He skipped into the room, and then she heard him chant some sort of prayer in front of an altar.

"What a fool".

"It's bad".

"Why doesn't she understand it?"

He came back inside, driven by some strange thrill he untied her wrists. Before she could get up he turned her - chair and all - to face the wall behind her. 
There was a painting. She had guessed right. A portrait in a thin frame. It was... it was a female figure, with a long delicate face and her hair tied in a braid.

It was... it was her!

Not her now, obviously. It was her as a child, more than twenty years ago, with her hair tied in a braid and a bunch of metal on her teeth and glasses to help her with a slightly crossed eye, though it hadn't been depicted in the portrait. It was her back then, more or less.

She wanted to shout, in surprise and terror. But she stopped herself. An impulsive reaction would ruin all the work she had done the days before. She shouted on the inside, thoughts flooded her head. All the details seemed to float about in disarray until gradually they started to come together.

The boy that had saved her. The boy from the accident. The one who had taken the blow in her place. They said that he'd stayed in the hospital for months. They said that he had gone mad, or been paralysed, and would draw her portrait every day. Nothing more than a novice's scribbles, but over time he got better and better, until his paintings became life like. Until he managed to capture her soul without ever seeing her again.

The boy that had saved her life, had grown up. A lot. He still had the same kind eyes that had a madness to them when he lost control and he did things that others wouldn't dare to do.

Like taking her by the hand and bringing her into the other room and asking her if she noticed something different. Another portrait was hanging on the wall by the entrance. Jane didn't remember seeing it there before.

It was a woman. It resembled her, it was the young girl from the painting, as an adult, conjured up in John's mind. She has grown up in his imagination as he had grown up. Jane looked at the woman in the portrait with a strange sense of familiarity. It was another version of herself, a strange illusion, a complex combination of reality and fantasy. 
Her ill-concealed horror had almost given way to admiration. He was good, she had to give him credit for coming up with something of the sort. He was very good.

Next to her, John seemed puzzled. He stared at the painting burdened by his thoughts, overwhelmed by something that stirred a profound reaction in him.

His eyes were feverish, his voice became almost hysterical.

"Never lose faith. That's the secret".

He was talking to hide his thoughts.

"Never be disheartened. Follow the path. That's how you achieve your dreams. It is something mystical..."

He spoke as if he were in agony and his tone was very serious. Then he would look at her, asking again for compassion.

"You have to be selfish to achieve a dream. At times indifferent. And at times cruel even". Jane could sense his underlying agitation. A relentless, compelling impulse. A feeling that drowned him.

"Love harbours all sins". His eyes were lost in some abyss. He showed the symptoms of a severe illness.

"I love you". John shook as he said it. And Jane beside him. For the first time she realised the enormous power she held over him.

The weeks passed, and the season was strange. Autumn seemed more like a rainy and humid spring. It was peaceful, the sort of peace that comes from quiet resignation.

There was no contact between the two of them. In the beginning it was more like a truce, which imposed cautious behaviour from both; then, a strange form of distant love developed between them, as if by cross-pollination. Intimacy made of hints, fleeting glances and 
unspoken understandings. A pleasure taken from the smiles between them and from the thrill of this mysterious power.

John was content with just looking at her. He kept her captive like a flower in a greenhouse or a fish in an aquarium. He kept her there and idolised her and focused all his energy on keeping her there. He was afraid to touch her. Hope and resignation were too fragile and wild to touch.

He was honestly convinced, or perhaps deluded, that over time something would change. It was a long road, the start of a long road, and what was at the end one couldn't say. It was a matter of waiting.

And so he waited. There was all the time in the world and now he felt calm. There was a light, refreshing sea breeze on his face; there was the sound of the sea, the peaceful sound of the tide coming in and out against the sloped shore. A quiet and familiar anxiety. Jane seemed satisfied with the new start to their relationship. After a false start, now it felt right. It would have been perfect, had she been able to forget what had happened before. But, of course, she couldn't.

Some days she felt broken, others she felt joyful; and she found nourishment in that unstable feeling, almost as if it filled her with energy.

She wasn't happy, obviously, but at least she had gotten her revenge.

Absurdly, she felt that she was exercising an immense power over that man. A gesture, a grimace on her face, a trace of her mood was enough to steer his behaviour. And Jane seemed very pleased.

She liked his attention, his docility, his sincere submission. She liked how he showed her that he was willing to serve her. He did everything and anything so that she wouldn't have to do a 
thing. Like a doll or the girl in the portrait. He made her feel small but important. At times extraordinarily important.

It happened quickly, one day they decided to save themselves. Following a series of fortuitous events and spontaneous actions. They had built a complicit silence, a tacit agreement, renewed each day with looks and hints which they understood perfectly. A way to live, or to survive rather, based on a shared unspoken understanding. What had happened, their dark and shocking secret, had been repressed: erased as if it had never happened, and neither of them would ever use it as a weapon, as a club to hurt the other.

It was a balancing act: you must keep your feet on the wire without ever falling. This was why they spoke as little as possible. They were even cautious about their thoughts, holding on to them tightly lest they escape their grip and fly into the air and become visible somehow. Fear withstood everything. Only this. Fear and the hidden desire to discover what the other felt.

It was a ridiculous system, but it seemed to be working perfectly. But there was one chink. John couldn't help looking at her. It was the one thing he couldn't stop doing. He could promise, without the need for words, that he would keep their secret. But he wouldn't forget it.

A dog on a leash that pulls and pulls until slowly it loosens its hold... He liked looking at her, she was so beautiful, and to think he'd been with her.

Then it occurred to her. A flash of doubt, an allusion. Free from his mind-games, she could then see it in his eyes: there lied the obscenities hidden behind all that unnatural attention. 
Jane didn't crumble instantly. She tried to drive her thoughts away, the snake's tongue, and the devil's evil tail swinging.

She was nearly there, after all. She almost believed that this was the only possible life she could have. She had never been so passionate or carnal, she was no longer living a hypocritical life. And it seemed to her that the pain, the anguish and the danger were the price to pay for that intense feeling.

In the end, it wasn't that bad. He had his reasons. He had saved her, after all, long ago: whether she liked it or not they were bound together.

Then she saw it.

Again. She found it where it had always been.

She hadn't noticed it for weeks, but it was still there.

The rusty billhook had been left between the bucket and the spade.

It gleamed in the ray of sunshine that filtered through the window, the polished end shone. It was still useful. It would serve her purpose.

John was next to her; he had just come back from his afternoon trip. He was playing the farmer, this time. He had a shrub in his hand, taken from the soil with all the roots intact, he bent down to transplant it into a pot.

He turned his back to her; he was no longer so cautious with her.

She could reach the weapon without him noticing.

Her hands were shaking.

She could, before he would see her.

She could. New York and the bar, the chaos of the lunch hour, the revelry of parties broke away from the shadows and fell on her again. She could be free now. 
Two steps, a quick dash and he wouldn't notice a thing. A few decisive movements but decisive, without making a noise, and the game would be over. He...

He turned around earlier than expected and his look made her freeze.

What was she doing?

Immense disappointment washed over his face.

Don't do it, I beg you, don't do it. Just when things were going well, they loved each other, and they had been on the right path to a stable relationship. To do it right then, would have been wicked.

Frantic thoughts passed through his head; his arms moved about hypnotically as if he were drawing in the air.

Don't do it - he had a powerless look in his eyes, filled with this deranged delusion.

She did it.

She grabbed the billhook and stabbed him.

What was meant to be, would be... At this point she no longer cared.

She brandished the billhook and blindly hit him.

She pierced him.

Out of the corner of her eye she saw blood spatter, wildly: the man halted, stunned. He brought his hands to his stomach, he let out a moan and collapsed, and in one fell swoop he lost all his bravado.

She collapsed too, falling to her knees, covering them with the blood that pooled on the floor.

"John", she called out. Then she paused.

"John!"

She burst into tears. At the height of the pain. 
A foot away from her, John lay as he had fallen, with his eyes wide open, and his mouth hung open, in a puddle of his own blood that was getting bigger, spreading out across the wooden floor.

What had she done?

Why hadn't she stopped a moment before?

She had to do it, to understand how absurd it was.

Now it was too late. She could only hope that she hadn't cut too deep. An artery, the liver, a kidney perhaps.

The blood flowed out in a slow, thick stream: she thought she remembered that this meant it wasn't arterial injury. Then she realised the wound was on the left. Not the liver, thank God. She just needed to stop the bleeding. She tried to stop the stream of blood with the rag that had been used to gag her as a prisoner. It got wet and turned red. It was soaked with blood in a few minutes.

She tried to stay calm. She had to hold it together, if she wanted to have any chance at succeeding. Drops of sweat fell on to the rag, dripping on to the drenched cloth and then directly on the wound. It could cause an infection but no more than anything else here... Enough thinking: she needed to trust herself and act quickly.

Alcohol, she needed alcohol to disinfect the wound. And then something to suture it. In the survival training she had learnt more than how to just read a nautical chart... She left the rag to soak up the blood and ran to search for the first aid kit. She had seen in on the boat and was pretty sure that John had brought it up to the hut. She found it in a cupboard: there was alcohol and a ball of gauze but nothing she could stitch him up with. 
She went back to the man. There was now a large pool of blood on the floor but finally it had begun to clot. She looked around. She quickly searched among the nylon reels used for the fishing lines looking for the thinnest one. She went back to his side.

John was unconscious. It was better that way, she thought. For a moment she feared he would react, a cruel resurrection from his inert body. She was frightened, maybe she was losing precious time.

She applied the alcohol. She used the gauze to stop the bleeding and applied more alcohol. After a while the blood became sluggish. She applied the alcohol once more, a lot of it, and then she prepared to operate. She had seen it done in a few war movies and in a few comedies that made fun of war movies. To sew up a wound as if it were stitchwork. She began to thread the needle, with the nylon attached, through his skin, pulling the edges together, tying a knot to fix the last stitch.

She was learning as she went. It was honestly the bloodiest and most ridiculous thing to do. She prayed it would be quickly over, but when she had finished much before night fall, but she still felt she had taken long.

She was doing fine, considering, but she felt dazed. Her hands were still smeared with blood. She ran outside. Finally, fresh air. She threw her head back and looked out into the distance. She leant against the shed wall, slipping down the corrugated iron until she was sitting on the damp earth.

She looked out at the clearing that surrounded the house and a green wall of wild bushes, some type of rushes, and up above a blue expanse, clear and smooth like a sheet of icing. It was the sky. It had something false about it. Something tainted, misleading. Something that dulled her senses and somehow made her feel ill. 
And right in the middle of the sky, fixed up there was the moon - a trinket absently watching. A button moon, sending out its shining ancient call. An open eye that watched her, a nipple, a miniscule opening out of her agony.

"Why?"

His voice sounded different. More fragile, less weary. With no intonation.

Jane looked down, she didn't answer.

It had been two days and John's fever hadn't gone down.

The wound had swollen around the stitches and the scar had begun to fester. None of her attempts to stop the infection had produced any noticeable results: Jane had used all the iodine she could find, but clearly, she needed other medication.

John himself realised this in moments of lucidity, between delirium and foreboding indifference. He asked for help, pleaded for his soul and solemnly uttered incomprehensible sentences. Then he would fall into a delirious unrest or into the maze of an impassive halfsleep.

In spite of everything, there were some encouraging signs.

John refused to give up his life cheaply. For two day's it seemed as though he would die, but he didn't. For two days the weather was nice, despite it being in the hurricane season, and the sky promised more days of stable conditions. It would be difficult and dangerous, but they couldn't lose this chance.

With some apprehension Jane considered what she had to do. Since she had decided to leave, there was no point delaying it.

She didn't care to plan. At first light, she grabbed enough supplies for a couple of days, and put the man in a wheelbarrow (the day before the incident, John had fixed the misshapen wheel) and off they went into the woods, away from the shack, and beyond the clearing. 
The instinctive foreboding had awoken the birds, but no sounds came from the more frightening beasts as they were still dormant. She headed towards the beach, following the track that John had described to her in his new, feeble language.

She found what she had expected, this was the scene she had played out in her head many times. The beach was where it was supposed to be. A strip of sand, foam and crashing waves, debris brought in by the tide, piles of tangled up seaweed.

The boat calmly floated in the bay, a few metres from the line the sea drew on the shore. From the shoreline you could still see the ramp that had been used to get the boat back in the water. It wouldn't have been easy, for just one man. Not easier than helping John through the shallow water and supporting him step by step up the ladder that protruded from the bow. For a moment Jane felt like an amazon. Somewhere between a romantic heroine and a "green beret" in the army.

Firstly, she inspected the boat. She checked that there would be no issues with the navigation. At a glance, a couple of planks seemed rotten. Their position and how they curved must have prevented them from being repaired.

But they would face the journey, nonetheless.

At least this would be easy. With good weather they would take half a day at the most. She put the supplies in the icebox and pulled up the anchor with some difficulty. She kept John safe, in the cabin bed under the deck, the same bed they had been in that first night, her memories from that night were still confused. She carefully carried out the instructions to take off.

After a few vain attempts, she pulled the cord with enough force to get the engine started. She took the helm and steered the boat out of the bay and then, once out at sea, she set the navigation system to a steady course north-west, which in a few hours should take them near Daytona or Cape Canaveral. 
It was a beautiful morning and as they were leaving there were white clouds high above the mountains in the distance.

The fishing boat sailed at full speed. The boat caught an early dawn breeze and sped along, the prow cutting through the waves effortlessly. Jane watched everything as if it were in slow motion, looking at it frame by frame, as if to savour every inch of water.

Then, once they were far away from everything, the trip became less certain. All directions seemed the same and each one threatened to be the wrong one. The instruments on board showed the route, but Jane was evermore unsure. She thought that without him, without him regaining consciousness, she wouldn't be able to make it.

Signs of change appeared in that great, restless body of water. A flock of seagulls had gathered around the boat, jousting with each other. They would fly in circles and then drop straight down perpendicularly. Shrieking and squawking: they seemed excited, drawn to something rotten.

Jane watched them anxiously. She had a strange feeling; she was afraid of something. She was worried about John.

She went back down into the cabin and found him in the same position as she had left him in, pale and flushed with his eyes closed and his face angled towards the foot of the bed. She changed the dressing and sparingly applied the iodine, then went back up to her spot on the deck.

She couldn't calm herself down. The navigation system showed the course, the engine roared, they were still making progress, but it was taking a little longer than before. But it wasn't enough. 
There was something in the sea. A painful vigour, a stifled excitement. A slipstream or a reflection. A glimmer of something that had once been. Or something that was about to arrive.

The sea had stopped being the sea and had become a symbol of an indistinct something else. They sailed peacefully for a few hours, but the coast was still nowhere in sight. Then something strange happened. The flock of seagulls gradually dispersed and then vanished. The cloud's shadow passed over the boat. Other shadows appeared on the water: dark patches of water, islands in the stream. More of them, more often.

The fishing boat began to struggle.

The sea became wilder. The waves crashed and the wind blew seas-pray over the boat. The boat bounced amidst walls of water, rising and falling as it tried to stay on course. They were in constant danger, rising and falling at times they almost disappeared below the waves. The scene changed again. The prow no longer cut through the water. The boat no longer rode the crest instead the waves crashed against the hull, on either side, like a herd of crazed buffalo. Before the waves broke, they became almost transparent and the sinister stormy light pierced the water. The crests of the waves were scattered into the wind as they thrashed into the deck from all sides. Below deck, the sick man was thrown about in his bed. Without giving any indication of what was happening to him. His neck was contorted, a result from the battle he was fighting inside him.

Shut off from the outside world, his body twisted into the shapes of his hallucinations. His eyelids were shut tight and trembled as if he were being electrocuted. He was impervious to everything that was happening outside. Oblivious to the tremors and the troubles, as the south-west wind whipped up the storm more and more. 
The semblance of a siege now appeared complete. Even the sky, up high, had been taken over by a solid front of dark clouds. It calmly and ominously advanced on them, faster than their attempts to flee.

Between the tumultuous sea and the low ceiling of clouds there was a tiny gap, that in fact was an immense space stretching out towards the horizon and there was what was left of the blinding glow that had preceded the storm. A sombre, heavy, blue light.

The boat's torment unfolded there - as did Jane.

As the keel rose and fell, so did she, and so did the lump she felt from her throat to her belly.

Then she and the keel stopped their unsteady dance and continued to suffer an endless battering from the waves.

The sea matched Jane's struggle as she kept trying to re-emerge. Just as she escaped from the belly of one wave, the wall of the next was upon her. It hit her head on, blanketing her head with a leaden veil.

Jane struggled to breathe. Every shake, every wave that broke plunged her into the darkest part of her soul. And there she was, she had lost herself and she had lost the man and everything that gave her joy, a joy she had once found in everything. And there she was, she had lost herself and she had lost the man and everything that gave her joy, a joy she had once found in everything.

But then, once the mantle of the wave fell and she found herself unscathed, everything looked different. It seemed as if she were in a wonderful nightmare where nothing could affect her. She faced everything with her head high, clinging onto her desperate strength, with a proud awareness that there was nothing to be done, that she couldn't react and there were only blows to parry, a glimmer of hope, and saints to pray to. 
It was like a proverb, a fable or a fairy-tale. One of those rare and precious moments that life makes sense.

She should have been trapped in it forever, cursing the impatience that desired her freedom. Cursing time's need to find an ending.

When he awoke, Jane sat in front of him. She was in shock and she was tired but now revived with hope. She had been sat there for hours. She has slept, woken up and fell asleep again for a little while but then she hadn't been able to sleep anymore. She watched him sleep or die, paying attention to everything, breathing as he breathed, breath by breath.

Jane cried when she saw him wake up; at first, he squinted then his eyes were wide open, like a baby startled by the light. She let out a sigh of relief and cried for the narrow escape. She was confused. Her hatred for John had driven her this far and the storm had taken her who knows where and if she had lost him too, she would certainly have never found herself again.

It was an absurd story, and it could have ended as a very sad story. Like this, instead, it resembled a twisted story of redemption.

When his brain cleared, John understood that he had pulled through.

He looked odd, a little robot-like, the cross-stitched wound on his stomach resembling a zip. But anyhow he had pulled through.

It was yet to be seen just how recovered he really was, he wanted to test himself to get out of bed and walk about. To see rather than just to feel it.

He already knew from the moment he opened his eyes; in fact, it was the moment before he opened his eyes. 
His first movements were disjointed, he trembled, he had to learn again to move again, to speak in a firm voice. He was disoriented, disconcerted by himself and at times extremely sad. But it didn't matter.

He didn't care about the pain, the wound, the ugly scar, the boat, the island or the open sea. As for Jane, he no longer cared about her. She had been cruel: she had betrayed him when it had gotten good. He didn't care anymore.

He couldn't care less. He couldn't care about anything. He knew it.

He had seen it... materialize, take the shape of a body and it let out an uncontrollable roar. He witnessed God save him.

It was cold, up above on the bridge. The sea was black and swollen but still calm. The wind chased the clouds across the moon. John fiddled with things in the cabin. He adjusted tools on-board before quickly joining her.

He was back in her service. Like a page boy or a chaperone. Like a domesticated animal, eating out of her hand. He stood next to Jane and thought about her, trying her keep her there. For a while he seemed to be back to his usual self. Calm and controlled but shaken by sudden storms. But this wasn't true.

Jane forced herself to be obedient. She didn't suffer the cold. She didn't suffer through the night nor the loneliness. She only had a bad headache.

She had to say something.

"Be the good guy and let me go".

Silence. The faint lapping of the sea. They were still, they'd been drifting who knows where, headed who knows where and she had lost control.

"You have been good. You could be even more so. Let me go..." 
As the wind grew stronger, shreds of foam appeared in the water. John signalled that he was going into the cabin and she followed him. The sticky heat of the larder embraced them.

"Deep down you know it's right".

They descended together.

"You know it's the only thing to do".

John stared into space.

He stood there. He didn't talk. He stood there like wretch just so he could be close to her. But Jane didn't care one bit: she still hated him. Now that he was no longer going to die, again he had become the oppressor.

They had rolled in the filth together...

"Let me leave... It's the only thing you can truly give me".

Her voice dropped off at the end. It was almost a murmur. She could no longer control her melodramatic tone.

John's eyes remained fixed on an inexistent point in space. He was balancing an invisible object on his nose: a ball or another precarious body. Then...

"You hurt me, and I hurt you; you saved me, and I saved you. We're even". ... he bowed his head.

"Now stop".

He coughed and stood still, lowering his head. Jane's confused voice echoed at the edge of his brain.

Then it slipped away, without leaving a trace.

Nothing could touch him. For a long time, he had lived with death hanging over his head and had a rather detached manner about it. 
The pain had twisted him. It had sharpened his senses. He saw things that hadn't existed before, or maybe had never existed.

The pain had altered the world around him. It didn't make it bigger but smaller rather, drastically and bleakly smaller. Many things that perhaps existed, had been reduced to a single thing, that perhaps didn't make sense.

It was no longer her. It was about him, and it was inside him.

"Do you understand?"

"Yes". John's voice was dull.

He raised his head.

"Did you really understand?"

He narrowed his eyes.

He didn't say a thing, but he looked at her from afar.

He looked her in the eyes, from below, as if she were disproportionally big. She was no longer herself and she towered over him - an abyss now separated them - and she possessed all that he lacked: thoughts, emotions, memories and feelings that he would have otherwise lost. She was it, his whole life, and this couldn't be stopped.

He saw her becoming ever more distant.

From afar, ever further away, he asked her that he be dust under her feet, flesh in her mouth, and implored that she save him, that she keep him whole, and that they stay together.

She, instead, was asking to be free. She was life, like the wind, and nothing would stop her. She asked him to be alone. To get used to solitude, like overcoming death, and to surrender to the incoherent flow of his visions, to plunge into the screams and voices, shadows and dreams. Not to tame them, nor to keep them captive, but surrender to them. 
He felt something pull at his side, where his wound was. It began to rip open and revealed the edge of an abyss. Bloodless, starry, black.

A moment later he was on top of her. His hands were around the soft skin of her neck, their grip tightening. He watched her struggling to breathe, swelling up and moving her hands wildly. He didn't laugh or cry, he felt no emotion.

All he was doing was thinking, coldly. He was only going through the motions, coldly. It was what he had to do.

He would be able to do it properly. A little longer, still. Not too much.

Excitement, shut out forcibly from his brain, took over all the rest of him.

His eyes, his temples and his fingertips throbbed. His dilated pupils glazed over. Everything became bigger and bigger, then smaller and smaller. Then bigger and smaller again, ever so quickly, like a film sped up. And all the while the infection grew and spread, advancing and invading all his impulses.

A fiery wave flooded his brain. It swirled, violently, against the crumbling pillars of his better judgment. A wind, an infernal gust echoed through his head.

The cut on his side was pulling open and the makeshift stitches were about to burst. He noticed it belatedly, like an unimportant detail, a glimmer.

It was his hand holding something; swinging out of control, it struck her. A slash. A clear sound, a sharp cut through the air.

His wound tore open and her hot blood splattered into it, and her face pressed into it, unmoving. 


\section{The Prey}

An earlier version of the is story has been published in the Journal of Italian Translation, Volume XIV, Number 2, Fall 2019.

"God, what a catch!" The man was jerked forward by the powerful tug on the line. He kept his footing, as a good fisherman does, as a grown man who has seen it all does. He stayed on his feet and knew that he was close to landing the catch of his life. One moment, he took off the mantle of misfortune and the next he was full of pride. Its jet-black eyes glowed like live coals and its hooked nose gleamed like the beak of a bird of prey. He felt like he had hooked into the foundations of the earth.

And what a marvellous catch, God what a miraculous catch it must be. The spirit of resistance and the tempo of the movements made it very clear. The reel whirred frantically as the line ran down to the depths of the sea, unravelling almost to the end of the roll. And then it stopped and suddenly became taut, splashing drops of water in the air. The man's muscles tensed, trembling and alert, an involuntary reflex.

He had not expected to meet it in that place. Then nor ever, that wonder. Not there, at his home. But he was ready to swear, on what he held most dear, that the place was magical. It was no more than ten meters from the coast. It was not hidden, the way all magical places are. Nobody knew it was there, where the bay meets the open sea, a little further in, as soon as the tide lines appeared on the blurry mirror of the water.

Where the waters met, a sort of whirlpool was created. The tide lines stopped advancing and began following a circular movement. The water seemed dense and stagnant, yet it was just murky. And incredibly deep.

They called that place saltmarsh a strange intersection of sea and swamp. Without knowing that it hid, straight and sure, a path to the ancient depths of the seabed. Nobody knew, except 
for the man, who had kept his trabucco ${ }^{4}$ there and explored that stretch of water, inch by inch, free diving. When he could not go far, he tried at least to go deep. He had gone out that morning as well, without reading the signs of the sea like fishermen usually do. Without making a firm appointment with luck. Without longing for escape or pursuit. Without setting traps and mapping out in his head the sea's invisible paths. Just for the challenge and out of instinct. An urge. As if grasping wearily at the last chance of fate.

For a long time, too long and who knew how long exactly, he had lost his rhythm. Nor did he ever recall small things seeming so vast. He wasn't looking for anything, after all, he was not expecting anything special. Something worth writing in capital letters - that's what he wanted brought to the surface - a crumb of childlike wonder in the belly of his prey. He knew what he wanted - nothing much - and he had wanted it for some time now. To make sense of still being there after feeling for so long that it didn't. He wanted to catch something big and beautiful and to retrieve, for once, the rhythm, and he hoped that catch would give him all the answers.

For this reason, despite the strain, he held on. He slaved away but he did not exude one single drop of fatigue. The whole thing seemed incomprehensible. After all, he was fishing up a world, a completely extraordinary underwater universe.

He pulled with all the force of his inscrutable age. Once you would have said he was elderly; now that he probably was still in his prime. For this it seemed even crueller that fate had taken away everything around him. One by one, the supports and the footholds had been torn

\footnotetext{
${ }^{4}$ Trabucco is an old fishing machine typical of the coast of Abruzzi region, the coast of Gargano and along the coast of the southern Adriatic [translator's note].
} 
from his hands and from under his feet, until he was left alone. Like when the is sea shadowy and still, where anything could be friend or foe and any direction could be the wrong one. Floating adrift, he had lost his soul. He left it attached to something and now he lived to retrieve it.

Down in the abyss the prey revived and began its journey. Right from the start it travelled towards its end. Its slick and iridescent skin was an intricate patchwork of scales, peduncles and filaments. It floated softly, lying in the dark waters. It groped about in the dark and did not suspect the light. A far-off music, like a lullaby - the soft buzz of worlds and atoms above its head.

The huge body, shaped by freedom, knew no obstacle. It remained a good while, at least a couple of hours, deep down in the ocean. Then it rose at a slow and constant pace, almost imperceptibly. It barely felt time passing by. It rose, light-heartedly, with its dreams. It kept all of them together by not dreaming of them; it held them close unconsciously. So, unaware, the prey was one with his dreams.

Then it broke away. Slowly, the layer of solid darkness became muddied with reflections, confused emanations from a remote beyond. The life that quivered above it, past the surface barrier of the water, became a distinct possibility.

Now the prey began to move in a different way from before. Its huge body faced the obstacles on the seabed. Tunnels and bottlenecks, fake coral banks, underwater formations demanded that anything that could not follow must to be left behind. And all that was superfluous, beautiful and insubstantial, broke loose and drifted down to the seabed, in a colourful trail of debris. 
As it rose, the prey gradually shed its layers and peeled away. Its eyes which had been accustomed to the eternal darkness became incredibly small, gobbled up by the light. The tips of the rocks eroded the edge of its universe. Its uncertainties. And its desires.

The prey went into a frenzy. In the ascent it encountered anemones and cichlids, molluscs and coral fish that slowly became a familiar presence, like traveling companions. It was attracted to their bright colours, to the promise of a destiny that was not its own; it would have gladly followed their paths. The precise invisible seaways or the calm drift.

But it had to rise up. It had to return to its master, to the place it belonged, and all the waiting until that moment, the thoughtless slumber of centuries, had been merely a rehearsal. It had to return to its master now. But it was not a slave's surrender or a sacrifice without reward. Alongside the pain it felt a vague sort of happiness, the joy of a weight that was gradually being lifted. It could have peacefully remained on the seabed for many centuries, yet it would have never lived. It was prey and as prey it had a job to do. Take the bait, be caught and make that long journey upward. That journey, and only that, was its reason for existence.

Everything like it was at the beginning.

The man waited and the prey made the journey. But something had been different since the early hours of the morning. The scene for the marvellous catch had changed. The wind had dispersed the clouds and the greyed green colour of the water had become a bright light blue, streaked by foam.

It was hot and the sun beat down on his neck burning him. As if in a daze, odd thoughts passed through the man's mind. Now he felt that this day had already been written, he knew it. Something in this place had to happen.

Why he felt that way it was impossible to understand. One could try, but it wasn't something that could be logically reasoned. He sensed it, that's all. The sea told him secretly. 
And who still knew the sea anyway? There was no-one else left, who could read the secrets of the sea... Its colours, its movements, its moods... No one else who knew the wind, when it sweeps in and when it unnerves, unsettles, unleashes.

It was just for this reason he wished he had a son. Over the years he had begun to want somebody to talk to, to tell stories to, and there was nobody he could do that with. No-one who had to listen to him out of gratitude.

So be it, then. Nobody would ever know about the underwater ridge, about the sudden dip, or the deep well and the dark waters that appeared murky but in fact was just bottomless. Nobody. No-bo-dy. How many times did the word pop up in that silent conversation? His life was filled with nobody. Far away, non-existent, impossible nobodies. And this prey too was nobody, though he felt it as the most precious thing in the world.

A mocking smile, from above, turned into the gaze of an indifferent god.

A thick layer of clouds had darkened the sky again, a pale blue glaucoma which smelt of rain. Even the surface water darkened, without losing its transparency, so the whole seabed could be seen in the right light.

The well where he was fishing appeared as an abyss, unexpected and mysterious. A place no light from the sky could ever reach. Only he, and now a flock of seagull's intent on hovering over the chasm, knew where it was. They fluttered excitedly, flying very low to the water, with the wings outstretched and still. Focused like him. Dull in the same way. They had a comforting effect on the man. He thought of those who say that you are never alone unless you are a poet or an impotent man. The others, all the others in between, have at least the support of their shared normality, the invisible solidarity of many, many others. That complicated thought now seemed rather trivial to him. He did not know who had said it; but 
anyone might have, as far as he was concerned. Naturally, like living. Even the sea could have whispered that to him.

His drift snapped like a sluice. A blockage in the blood flow, a vortex in time.

It gave a clear impression of relativity. It could be an instant or eternity. A moment to think, dream maybe, but not live, at all.

It was all about letting go. Making himself comfortable, he waited as the prey made its way up, divining figures from the body of water. Incoherent answers, for the most part, unclear shapes. And then at times, amongst the tricks of the reflections, the image of something that made sense appeared.

That day the water rippled restlessly. The shadows dispersed and reformed, finally becoming dense and heavy, claw-like sharp like a memory that was still painful. The stifling grasp of a hostile city, invisible blades striking relentlessly at its stomach, the loud scream of madness: this was the effect of the shadows.

The man smiled bitterly. He did not suffer, he no longer suffered: he knew he could appease his memory. It was not the shape of pain; it was not what he would bring up.

The shadows suddenly became long and thin, like the bars of a prison. And inside that prison was his weakness, the slope he fell down to find himself no more than any ordinary man. He hadn't been that smart, not at all. He had been enchanted by her, by her mother, by her smiles and her charm, by the smell of her breasts and people's sound advice. He loved risk and he had settled for a peaceful life. He loved the challenge of the open sea and he had resigned himself to sail fishing boats. With the self-assured demeanour of a married man, he had divided his time between the weekly work and the mass in Latin, good meals and empty Sunday siestas. 
He had bent over backwards for her, waiting for a baby that was stillborn, and then for her alone, even if he was unhappy, even when he heard her groan in someone else's arms. He had never been good with words. He couldn't do anything. He did not love disagreement or distance. And for this too there was not much to be done.

He pretended it had never happened, even though everyone in the village knew, and when she died of cancer, a lifetime ago, he cried and never thought, even for a moment, that it was her rightful punishment.

It was a hell of a life he had lived, for a son that was never born and a wife that did not love him. That's how it had gone. Too late.

He looked at his hands gripping the rod and clinging, clinging to it furiously. He smiled and thought he had already come to terms with his regrets.

It was not regret he was going to bring up, it was not that.

He continued gazing at the body of water below him. A gust of wind stirred the shadows and they lengthened yet again, talking to him.

He would have really liked to play the harmonica. He would have liked to play in an orchestra, even if the harmonica was not part of it. Or maybe not? In the orchestra that he had in mind there was certainly the harmonica. A solo instrument with the dignity of a primadonna.

He imagined himself on stage, under the soft lights of a musical. The audience applauded and he was flying over the keys without even being able to see them. Effortlessly. Everything that he had tried to embrace, the multifarious rush of joy was suddenly, firmly his.

He imagined the concerts, the applause, the success. The theatres and his name on the billboards. And then everything all over again, better and faster. And then slower, heavier, 
misshapen by blurring lenses. The habit... And along with the virtual and feeble habit of an imaginary life, a strong awareness in the present.

He never would have been a musician, not really. It had been a whim, on occasion, but he didn't truly feel he needed to. And maybe he would have enjoyed it, but all the same it would have ended. Besides, it didn't really matter anymore.

He closed his eyes and resolved to turn away from his fantasies.

It was over, it was all over and there was nothing left for him. Except for this prey becoming lighter, this universe that was unravelling while it broke to the surface, this last chance fate was giving him.

Every now and then the prey jerked suddenly, a sign of the impact with the underwater ridge, but the man was by now effortlessly able to handle it. The creature pulled less, maybe, or maybe his muscles were getting used to the pull. Slaving away at it had almost become normal.

Suddenly he felt a pull that was repeated and continued. The tiring but flat flow of the line got stuck.

Halfway up, the prey barely rose, as if it was crossing a barrier of sorts: perhaps it had run aground on some underwater reef bank. The man could let his line go loose and lose hours of work as the prey tried to find its own way out; or insist, forcing it to overcome the obstacle. He insisted. He doubled his efforts and his hands begun to cramp; the rod started to creak at breaking point, but he persisted. Half an hour later the battle was won. The journey upwards continued without a hitch, at the same pace as before. Yet the load seemed somehow lighter: an impression, but it was clear and precise. His fisherman's instinct had not misled him: hitting the rocks stunned the prey, and perhaps hurt it, ending its resistance. He wondered whether he had made the wrong choice. 
It was always like that. To get things right he had to get things wrong. He had to get hurt to be able to understand. And who knows for how long and to what extent.

To do the right thing is the hardest job in the world. He had always thought that it takes talent or hard skin to pick oneself up again after every mistake. He tried to pick himself up once more. He let the prey pull away with the line, albeit too late, and hoped that the blood tinting the water wouldn't attract predators.

Too late... The trail of blood had already aroused the senses of large groupers and hunting hakes. The onslaught began, they came in droves, one after another, and after each attack the prey was lighter. Relentlessly, his world was becoming smaller.

Towards evening the rhythm of the sea quietened down and a strange silence descended. The lapping of the waves kept him company.

At the other end of the bay, the lampposts along the harbour turned on at the same time. Soon it would be evening, the lights would be reflected on the water and the beams would create imaginary paths leading down to the depths.

The man distracted himself staring at the seagulls. Their composed and fluid flight, a mixture of grace and functionality. It seemed they were made to fly and to stand out against the blue of the sky. The same way he was made for this day. To finally meet his challenge. It had taken sixty years... He felt as if he were one of those absurd flowers blossoming in winter, the hero of an American tale. He waited and the prey made the journey and the end was ever closer.

For the last hour there had been the faintest tug on the line. The intensity of the resistance had diminished, and the man pulled at the line sparingly, as if he wanted to delay the end, to savour each moment. Maybe he was scared. He was convinced that there would be no more 
dramas and the last stretch would be spent in a drawn-out dance of languor and courtship. But he was mistaken.

Out of nowhere the prey tugged and began to struggle furiously. Chasing before giving up. Life's last jolt. Endless endurance.

The man gritted his teeth. It was the most dangerous moment, the moment of desperation. The blood ran and the nerves tore, by some miracle the strength of the creature was magnified. Then long death would come, eternal and irreversible. But first he had to win the final fight.

He planted his feet on the rock, bent backwards and pulled the shaking rod closer, bent to breaking point, bringing up death. By now he did not fear death and deep down he already knew it. He lived as if he were already dead, deceiving himself. Death had begun a long time ago, he no longer remembered: it was boredom, dullness, that painful exhaustion that made him not want to live.

But that day his long death was interrupted. He had a whole universe, wearing away and nibbled at, but a whole universe nonetheless, to bring to the surface, ashore, into the light. He saw his soul where it was attached and expected to get all the answers.

He pulled the rod, nearly breaking it. The prey almost rose to the surface. It let out a ripping noise, followed by a groan, a sound of dying strength. The man and his firm composure were just winning.

The water opened into a whirlpool, an abyss, the vertigo of an ending anticipation. For one moment the prey stayed still in a strange position, poised between returning to the depths or explode out of the water. Hunched over, its back shining in one last, undaunted act of defiance. 
The man felt an odd sensation as it all came to an end and the shape of the creature loomed just below the surface. Suspense gave way to a familiar feeling that dulled any surprise. The gentle path of the heart's surrender.

At that very moment the prey burst through the last thin film of water and sprung to the surface. It was small, no bigger than a large box, the size of a man huddled up to protect himself. It had jet black eyes and a hooked nose that jutted like the beak of a bird of prey. In truth it was rather ugly. 


\section{Borges' Atlas}

An earlier version of the is story has been published in the Journal of Italian Translation, Volume XIII, Number 2, Fall 2018.

This book was dusty, silent and inconspicuous but extraordinarily alive in times of transition. Secretly it became animated, in the ocean dawn that would flood the large house. It shone, reflections of an intimate life while uncontrollable movements scanned the sunset. The rest of the time it was alone, like a sinister spirit or an unhappy or indifferent sage. Closed in on itself to meditate. As an inanimate body does, so it seemed, ignoring itself and ignoring everything. Instead, it was expanding, with details and fantasies proliferating.

It was a magic book. It contained the whole world as never seen before. The world as it could not be seen by human eyes. Not yet.

It contained the sum of centuries of knowledge. The weight of the seas and the pyramids. It was the fruit of a science, of a fervent fantasy, of an inspiration. Revealing the invisible.

It was only alive at sunrise and sunset. It came to life in the hands of a boy, the oblivious priest of a temple, who called forth from the pages the lost dreams of a dream. At both ends of the day, twice, the book and the boy exchanged promises; and the rest of the time they remained in silence, each nurturing their own loves, apart.

In the autumn of 1916, in all of Argentina, the Iribar family was the only one at war, even if the war was being fought thousands of miles away. Doña Angela imposed hunger and rationing, dreaming of an improbable restriction of goods imported from Europe. Nothing suggested that it would actually happen, but she had made her decision and she was the boss. Everything - the house, the herds, the hacienda - belonged to her.

Don Angel, her husband, was far older than her. 
He had been a respectable hidalgo, a nobleman, he'd built his family fortune, then he had softened in front of her beauty. He ended up locked into his room at night, as if in a deep-sea prison, from which he would intermittently recall, in a mournful voice, the good old times. Doña Angela slept far away in another room, as though it were a shelter where she was finally immune to his words. She would break the siege and let him rant away, then at daybreak she would effortlessly resume her position as the one in charge. Don Angel would burrow himself back into his usual gentle facade and she emerged in her armour of cruelty. During some tawdry quarrel, Luisito, both perplexed and amused, witnessed the end of their love.

Luisito was a "late season" son. He was the last gift from the heavens for his father and for his mother the unexpected surprise of a half-hearted love that had already been poisoned.

He was the son of forgetfulness. They conceived him in a moment of distraction, an absentminded and untimely impulse, an escape from the reality of their feelings. A rush of blood, which soon returned calm and logical when the urge had been satisfied. And then his father, mad, and his mother, hysterical, lost him in the drafty hallways of their enormous house.

Day after day Luisito floated through those hallways, a vague and intangible presence. He slipped through hose hallways, as if drawn down a slope or into a vortex by an irresistible pull, towards the rooms of music and weapons, of gym classes and calligraphy lessons. His older brothers were either preparing to be soldiers or busy with the business, the most difficult part of it, moving incessantly around the Pampa. His mother raged through the farm buildings like a revengeful demon, shooting fiery looks at the gauchos and servants. And his father, his old father, hardly spoke a word anymore. He blathered out of habit and never said what he thought. And mostly he preferred to be silent.

He had no truth to speak. 
In the middle of that eccentric circle, Luisito grew up a little odd. There was something different about him, as if he were a heretic or an infidel or had some sickness. He only lived in the dawn and the twilight. He existed and didn't exist. A boy dreamt of and then rejected by those who wanted him and then no longer.

He was a silent and unnoticeable boy but extraordinarily lively in times of transition.

He was the last one in that large house to have walked through the hallways, unlocked the heavy door of the old library and opened a book. He was the last person to do so after several million Argentinians and many more millions all over the earth. But nobody had opened that book in years, and nobody had ever found what he saw in it. The spine of the atlas had been waiting for his hand. It is not unlikely that the bond was necessary, decreed by fate.

It was a magical book, after all. Hidden amongst thousands of books in the little-known library of a little-known, respectable family that was part of the rural nobility of Argentina. It contained a most precious treasure, as simple and divine as a tree, a blade, a stone or the deities of a prehistoric cult. It was the guardian of an archetype.

Every morning Luisito got up an hour earlier than everyone else.

He slipped out of his room and shuffled in the half-light to the sanctuary of the library, that dark intertwining of visible and invisible dreams, pulsing unheard in the huge drafty house. He positioned himself under the sacred ray of dawn, the panes of stained glass casting a wash of colour and opened the book. From the depths of the Cave, he gazed out on the Platonic sky. From the other room - the door left ajar in case something needed to come in or out (some ineffable spirit, a life-giving force) - he could hear the voice of his father. A fragmented and incoherent rambling, alternating with bouts of coughing and lengthy sighs. Pitiful. 
For some reason he was convinced that his father was dying. Therefore, he leafed through the atlas with a veil of sadness. Like a book of mystery, a symbol of that other mystery that he was beginning to understand and which unsettled him.

In the Iribar house one died in a medieval way. From romantic, trivial illnesses, thought to be extinguished by that time. There wasn't any faith in science or any real desire to recover. Listlessness and resignation found their only counterweight in an extraordinary longevity.

But Luisito did not know anything of this and had no interest. He leafed through the atlas, looking without reading and that was enough.

On the map, in bright colours, there was the great barge of Asia with its tentacle that was Malaysia and the tail of the islands of Oceania; Europe carved out by the hand of an engraver, the jagged fjords in Norway, in the land of Baffin and at the very bottom of Chile; the triangle that was India and the pentagon of the Arctic; Africa, simple and dark as a prehistoric monument. And then America: The North, stretched out like crinkled parchment, and the South, broad and long, tapering down to the immense Antarctica, silent and confined in limbo. Bouncing back and forth between the poles and the equator, Luisito entangled himself in the grid of parallels and meridians, in the radial plots, the rough perspectives of the oldest maps. He measured the distances and compared the sizes. He followed the outlines of the seven continents, looking for similarities with the lines of a face or the shape of a figure. He traced incongruous routes that someone would have called "nautical spirals" and seemed to be the shorter ones on the map when in fact they were not.

Everything happened like a game, but it didn't feel like a game. Between half-awake and dreaming, fluttering on the edge, the child explored both sides of an ancestral doubt.

The front.

He travelled in a world that was not the world. An idea, if anything, a form, a geometric version of the world. The cartographer's hand had copied onto a map the proportions and partitions of 
the uncertain architecture of the world. But who could say, who could prove with irrefutable certainty that the entire design was real?

His work, his drawing in soft colours was the result of an illusion, an increasingly refined technical approximation but still unable to grasp reality.

The reverse.

It was the bark of doubt. That the world, even the world outside his walls, could be just as deceiving. The iridescent colours, the misleading impressions, the unstoppable rush of the appearances, the secret yearning of a palace built on water. The world, the whole world was an illusion.

To solve the mystery, more and more often, Luisito paused and pondered about the virtue of imagination, caught up in the idea that the only real world existed in his mind, and it depended on intuition and imagination, on how much he could glimpse beneath the veils of the wrapping. The book was a mirror, and it reflected the deepest depths of his eyes. In every blood red sunrise, every liqueur scented sunset, at every foray into the secrets of the atlas, the map filled up with hidden presences. From the hints and inklings in whispered tones, melodies like silence, Luisito sensed unknown surfaces.

There was a land that always appeared new to new eyes. A land that always disappeared whenever someone left it behind.

There were lands divided by vast oceans, their almost matching coastlines evoked puzzling correspondences and, who knows, an ancient unity. Luisito had fun imagining how they could have come apart and how to put them back together.

There was a land divinely symmetrical, divided by a meridian line as if it were the edge of a mirror, split into two perfect and opposite halves. In the reflected half, shadow of a shadow beyond the mirror, Lee had won in Gettysburg, the Saxons had defeated the Normans on the 
plain of Hastings and the Arabs had breached the ranks of Charles Martel. The ramifications of these events created enchanting labyrinths which no-one from the other half could penetrate. Luisito's mind had barely the time to imagine them before his attention was drawn to something else.

There was a land with a false Buenos Aires of an old memory. An earth yard and a pergola, a portico and a water tank, the taste of grapes and wet. And further on, scattered beyond time, the remains of Manhattan and Ur of the Chaldees, the ruined temple of Jerusalem, Carthage defeated and desolate, and Rome that belongs to everyone.

There was the land of white unicorns and the golden rain of Zeus's love, of the seven cities of Homer's birth, of a fish that leaps and a man who suddenly remembers that he was that fish. There was the land of the first moon and of the first sunrise and of the first time, all enraptured by the amazement of being given a name. The Earth at the beginning of logos, ploughed by wonder, empty of everything but words and myths.

There was also the nocturnal land of his father, the dazed homeland of mad men. And close by, attached by a small isthmus, the dark destination of dreams, the place of a god who sees all, knows all.

And how many more were there, that he couldn't identify or didn't know how to describe? At every honey sunrise, at every fiery sunset, Luisito discovered new lands, new dreams, new labyrinths that intertwined with his life. They covered the map to its limit and thickened an intricate pattern until it became inextricable.

Every day the outlines faded, the colours dimmed, the impressions blurred and overlapped. Until one day, as he opened the page, all those lands seemed to him just one land. One sea. The desire to divide and contain had been overcome. All of a sudden, everything appeared as it really was: an unstoppable flow of being and not being, an explosion of atoms, a luminous 
chaos, and nothing even remotely like the cosmos. Everything swelled into a wave, the unstable state of matter, water that flowed back and forth on itself, never still.

The atlas of the sea. This was the magic book. A sea of lands made of sea.

The prelude to magic. The soul of the world and the secret friendship between all things and the sacred power of details.

Coexistence. Merging. Absence of contradiction.

The paradox.

This is what the Atlas ultimately taught him; and it was repeated by the petals and thorns on his mother's stem and by the sad evolution of his father. The map of the world, its pretence unveiled, his mad father, the chaotic order of the drafty house, all continued to exist in his eyes as a living paradox. More than anything else, his father.

He could not imagine a paradox. Not with ideas, the abstract figures of the mind. But there was his father.

At night his father questioned himself. His whole life now turning against him. He resisted the dark with insomnia, the emptiness of death with the stubborn longevity of his family.

He fought the bottomless oblivion and the abyss of darkness with his own name, his ancestors and his blood, the words and the tears, the fruits of the vigil, the illusions of the light, the line and the curve, the logic and morals, empires and dynasties, mottos and verses and the consolation of a lost love.

Instead by day, when the semblance of gloom dissolved and the spectre of the Last Darkness no longer scared him, he wandered around like a pale and yielding ghost. If he had to die, it was better to be already dead. On the other side of death, he expected to find out the answer, whether he had been someone or just a word. 
Those who saw him only during the day, admired him without knowing the truth. Since he had to die, he was already dead: only his father was that brave. 


\section{Finis Terrae}

Grande mer de délires douée peau de panthère et chlamyde trouée de mille et mille idoles du soleil.

(Paul Valéry)

"Gli animali proverrebbero dall'umido che viene vaporizzato al sole; l'uomo poi sarebbe stato, al principio, a un dipresso simile a un altro animale, vale a dire a un pesce".

(Anassimandro; da Teofrasto, Opinioni Fisiche) $)^{5}$

Emptiness. The young sperm whale, a male weighing twenty tons and ten metres long, looked around, confused. Emptiness, all he could see around him was emptiness. The sea, his element, had turned into a solitary desert.

"The pod, my son, the pod is our only hope... Follow the leader without thinking too much. Leave the leader to do the thinking for you. Trust me!"

The patriarch's words bounced around in his head like a frightful scream or an echo that seemed to be getting further and further away. Damn him! He lagged behind only a mile or so, just the amount of space the young need to prove themselves. Suddenly he found himself alone.

"Follow the pod, my son..."

But, how could he? He had seen the Grey Giant.

It had been not more than an hour since it had happened. He was motionless, stretched out in all his amazing length under the bright sky and the scorching midday heat. He had seen him

\footnotetext{
5 "Allegedly, animals originated from moisture as it vaporized in the sun; and man, at the beginning and for some time, was similar to an animal, namely fish" [my translation].
} 
glittering in the sun, just out of the water, soaked in thousands of droplets glistening like gems. Against the light he had seen his large outline against the horizon.

He had no choice, he had to follow him. Instinct had driven him, a violent uncontrollable impulse that overwhelmed the advice of the old patriarch.

After all, it had been the old one who had put the story in his head, a tale with the tone of an epic and the purity of a lullaby.

"Once upon a time, at the beginning of time, there was the unknown and primordial water kingdom: a secret place, hidden from the world deep in the midst of the outermost seas. As the light filtered down, it made the coral and mother of pearl glisten, the plumes of seaweed and the sea flowers swayed to the rhythm of the current, everything quivered with the bluegreen mystery of caves, sea-beds and vast sandy expanses. Down there in the depths of the utmost unfathomable abyss, lived the first sperm whales: peaceful opulent beings, made enormous by their enormous thoughts. The first pod, in which a forefather of my forefathers was the youngest calf, followed the path of a mythic creature, the greatest to grace the sea, a specimen of incomparable size and unusual colour, perhaps a sign that he was the chosen one. They called him the Grey Giant.

A signal from him was enough to excite or control the pod's will; a turn of his head, a flick of his tail stirred an entire crowd. First of the first, it has even been said it was he who mapped out the edges of the world. But when he returned from the journey, he was never the same... The endless wandering had made him infinitely melancholy and unbearably bored of the sea: exhausted by the storms, the hours of peaceful splendour became tedious, he longed for more.

And so, he left the beaten track and dared to follow the path of light, forevermore renouncing the quiet of the sea, for the damp silence that made it perpetually equal to itself, a non-place with nowhere to dock nor any bearings, immersed and swaying in the eternal present. The 
Giant wandered for a long time, in and out of his imagination, and then one day, finally, he found a gap in that vast prison: with the last of his strength, a grand unimaginable move, he shattered the confines of time and he emerged and found himself under the sun, he looked about. He immediately called the females to come and look and he took the calves on his back to hoist them out of the water. Together they discovered empty plains, sumptuous scenes, flooded with golden rivers and a pristine turquoise sea above their heads. From then on, that image remained trapped in their dreams. Every day of their lives they strove to attain it. On the back of the Grey Giant and then on their own, the pod rose to the surface; following the underwater ridges and the beds of ocean currents, they reached the land above. They dreamed of leaving the sea, growing legs and wings to live on the earth and in the sky. hanging from the thread of this dream, they became smaller and lighter, they learned to balance on the ground and leap into the sky, darting and twirling about, lords of infinite space. But they found no more certainty in that immeasurable vastness than in the quiet comfort of the deep. Faced with a universe that stretched out endlessly, they felt an irresistible desire for the essential, a burning thirst to go back to the start. Then those inhabitants of the sea split up: some remained in their new form, faithful to their longcherished dream of freedom; others returned home, to the sea, to the place fate had originally chosen for them.

Only the Grey Giant remained in that precarious: stuck in between, his enormous body divided between the land and the water, fish and man and fish again, in continuous metamorphosis. From that day on, the sperm whales relentlessly searched for him, pretending to migrate in search of him throughout the many labyrinths in all the seas, surfacing as they once did to breathe in air. And so, they lived this way, roaming with no destination, lost 
between the depths and the sky - the depths that guarded their secret and the sky that cherished their magnificence."

The young sperm whale cursed his luck, again, more fiercely. Because of that fable, that sweet well-rehearsed lie, he was now risking his life.

For many seasons now the old patriarch had been leading the pod on improbable routes to avoid encountering other pods or running into some lonely male, sated with freedom and ready to fight. Day after day the old one became weaker and felt the time when he would have to abdicate was coming: avoiding confrontation was the only way to postpone this outcome and retain his control over the females and the offspring.

And so, the pod travelled along the outskirts of the temperate seas, on the edge of the waters too dangerous for the young ones: pale with freezing currents, swinging between dense darkness and violent brightness. A moment's carelessness would be enough to cross over, to leave safety and enter the realm of doubt and death.

The young sperm whale had already taken that step beyond and now struggled desperately to turn back. But only a miracle, a lucky twist of fate and circumstance could save him.

He couldn't see and could no longer distinguish with certainty which direction he was going in. His big cerulean eyes, accustomed to the underwater gloom, were stabbed by the bright light.

He was drifting away.

The waves, that submissively followed his movements, had now grown, towering above him. He gasped as after a deep dive; he must go up for air at any cost.

Meanwhile, on the horizon, the Grey Giant had disappeared, swept away by his own proverbial disquiet or turned into an island as in the classic myths. Perhaps he had never been there, nothing but a mirage, an absurd illusion of a warped mind. The weight of the hoax 
made the sperm whale pant in anger and pain. It became more and more difficult for him gather his thoughts.

He tried to look away from the sun, but the sun bounced off the water and still caught his eyes. For a moment as he looked past the pain, he could see a strange turmoil in the sky: a swarm of sea birds, swallows, starlings and cormorants, had come to witness his suffering. They twirled about mockingly, then swooped down to get a better look.

The young sperm whale thrashed about in the waves; his expression frozen into a mask of genuine terror. He was caught in the stream, as if it were a tunnel, with all his nightmares and his desires. There was nothing to do, he thought: the relentless tide would push him to the edge of the world.

Then he stopped fighting. He closed his eyes in surrender, letting luck guide him to safety through the many hurdles. He thought he would get sucked into a whirlpool or thrown crashing into a rocky outcrop, instead he ran aground on the small beach in an islet on the edges of the ocean.

He heard the sound of a punch and a twinge and then silence all around his heart.

II.

"Finis terrae..."

The lighthouse was not lit up, it stood backlit, dark as a bird perched on a cliff or a sinister sign, between the earth and the sky. An unchanging dark mass, suspended between the true blue of the sea and the vanishing mist, in a magical realm.

"Finis terrae..."

Shut in the control room, the lighthouse keeper pondered the mysterious aura and the sense that something magical had just happened. He slowly unfolded a nautical chart adorned with arabesques and strange figures, roaring lions, wild dragons flying above the waves and 
snakes tangled curiously in trees. He stared at the page in search of something. On the map of the seas Ouessant was at the very edge, on the yellowed rim almost at the end of the world. Finis terrae.

Claude René Valery was the keeper of the Ouessant lighthouse. His father had been a lighthouse keeper, his grandfather had been a lighthouse keeper, his family had been lighthouse keepers for the past seven generations. He too had always known it would be his destiny to be a lighthouse keeper and had prepared himself for just that: the naval academy of Brest, a specialization in convex lens optics, followed by winning the public competition that made him the entire staff of the Ouessant lighthouse. What may have seemed to others a dreadful sentence to solitude was almost a blessing to him.

Claude Valery felt he had been appointed to a sacred task: he was a lookout to the unknown and the host of the known world; the god of liminal places, clinging to the edge of the solid world and at the same time dangling over the abyss of the uncertain and the unexplored. Claude was proud of his mission, but not in the way that other men might be. He felt no need to show his pride to the world, but rather just to feel it in himself.

Day after day he stripped himself of every desire, of every other ambition of any desires, every other ambition, to adhere completely to his role: a man marvelling at the world and wrapped in its mystery, who braves the sea for adventure, reaches the furthermost limit then rests, tired and content, waiting to leave again one day.

Going to Ouessant had been the challenge of his life, an act of contempt towards his youth and at the same time a chance to grasp what other people's lives barely touched: an infinite, inebriating sense of freedom. On the lighthouse island, aloof, Claude had found a mooring and plenty of materials to quench his thirst for the essential. Ouessant was his Eldorado, his nowhere, his little piece of mystery. 
There had been no choice, no toil, no obligation. Claude René Valery had always devoted himself to the unknown, as if he floated in some arcane stream; and by chance, or divine fate, the unknown continuously reappeared in his life.

III.

The first time he had found the unknown it had been in Ninetta's eyes. Some days, while they walked together, while they set the table or made love, Ninetta would go far away, and he had never figured out where she went.

He and Ninetta had met when they were very young, and they had almost unconsciously fallen in love. Now Ninetta was his wife... After they got married, when Claude was assigned to the Ouessant lighthouse, Ninetta followed him as the most faithful of wives, without enthusiasm but with devotion. Where she grew up women followed their husbands and shared their fate without expecting they would like it too: this was a privilege reserved for a few.

Ninetta was a country woman, with her feet firmly planted on the ground and a need for certainty, that badly matched the constant roaming of a sailor's life. To her, the stories of the sea were just fairy tales, like butter for bread, and bread came from field work, dirty nails and a broken back. Though she loved her husband and did her best to indulge his folly, she had not changed in the slightest over the years, staying true to her stubborn nature. Because of this she was Claude's perfect counterpart, his support and his balance; and for the same reason she would always remain an unknown island in his eyes.

The lighthouse keeper's love for his wife was at times conflicted... Sometimes, in moments of spiteful selfishness, he couldn't forgive himself for letting Ninetta's docile tyranny creep into his solitude. Flashes of wild strength made him disdainful, arrogant; and even the lightest 
of touches, the quietest breath, any trace of her presence, even distant but constant, would trouble him.

After all his solitude was also an alibi, a choice to be released, the freedom to break a pact and escape promises. But Ninetta's at times blind affection, and her inexplicable devotion, had in fact - though he refused to believe it - won his heart. Often on calm nights they would walk about near the lighthouse, and he would tell her tales. He talked of the sea, the moon, of how lovely it was to be alone by the sea under the moon. Ninetta didn't really understand but she stayed with him anyway and listened. She smiled and she kept smiling to make him smile too.

They didn't have children; this was the lighthouse keeper's last concession to his free spirit. This refusal eased the grip of responsibility on his wrists and helped him feel like he was still in charge of his dreams ... He was the last Ulysses, and his island was a ship stuck out at sea.

IV.

It was a cliff, rather. Just a cliff: this was Ouessant. A few houses gathered into a village, a maze of winding streets carved into the rock, a coast sculpted by the relentless flow of the sea.

A hundred, one hundred and fifty hectares, how big could it be at that time? It was a cliff that was only getting smaller: just a spur jutting out of the earth, isolated in the middle of the sea. The lighthouse keeper knew every inch of it. He could make his way around the island in a day and had done so thousands of times. He needed to do something new, he had put himself to the task of finding its soul.

“Quelle est vraiment Ouessant?", he seemed to be wondering. What is the real Ouessant? The good weather Ouessant, when the dazzling sun drenches the landscape and the island rises from the sea like a jewel or a fiery gem; when the solitary coast is green and peaceful 
and pale like limestone, when the sailboats calmly hum, and the bone-coloured sea foam drew smiles in the water.

Or perhaps the stormy Ouessant, when the sea snarls, the surf is enraged, and the wind wails through the village streets. When the waves crash into the jagged cliffs and the inlets, a tremor rises from the depths of the earth and shakes the island to its rocky core. The charm crumbled away leaving just a rocky outcrop, Ouessant cloaked in dull colours, embracing the shadows and the stormy mist, rising ever more grim and lofty.

But perhaps the true soul of Ouessant was elsewhere. It revealed itself in the unmarkable line between the light and the dark, the calm comfort of the nest and the dizziness of the wideopen space; it lived in the speed of passage, in the thrill of setting sail, in the cry "The sea, the sea!" it was much more than just a cry. An island, Ouessant was nothing more: a handmaid to the sea; and as such it lived to be reached and abandoned, devoid of certainties, without the firm consistency of the mainland. In the entire world it took up the space of a marble or a button, a tiny gap on the border between realms: a space so small and fleeting like a cloud, as uncertain as the evening.

V.

It was evening, just turned evening, when the lighthouse keeper decided to go out. As the sky began to fade, he started singing in his usual lighthearted tone.

"Nearchus the fisherman hates racket and loves the sun, so he goes offshore, alone in the middle of the sea, with all his thoughts".

From lighthouse tower enveloped in twilight Ninetta pretended to scold Claude and smiled: Claude's glance asked for forgiveness as he left, taking the road to the village. The same 
scene played out every time the lighthouse keeper needed to be alone. To go away and to think, as he said, and maybe he gave too much weight to his thoughts.

He took the road all the way to the village and carried on until he reached the other side of the island, where the greatest secret of Ouessant was hidden. But this time he didn't choose to go there, it was if he had been driven there by some force, by an arcane invitation.

The entire day he had heard the creature's whine - a faint piercing sound, a divine cry - and throughout the day he had tried to believe it was just in his imagination, distracting himself with his usual tasks. But now, in the evening, that constant bellowing had won out over caution and common sense and the lighthouses keeper's mind was suddenly haunted by images of monsters and creatures from the abyss, confused ramblings of lucky escapes and mythic beings.

And then, from the web of fables and marvels, that inscription came to him, "Finis Terrae": two words in Latin on the edge of an ancient nautical chart that the lighthouse keeper kept in a trunk as a relic. As he walked, he couldn't help but think of them... His journey to the most remote part of the island, in search of an obscure "genius loci"", was tied in some way to those words, both sinister and biblical, of epic proportions.

After less than half an hour's walk the lighthouse keeper saw a clump of houses. He crossed the deserted town, bleak and eerie in the remaining daylight; cold and beaten by the Ocean wind.

The village's fate had been decided in no less than twenty years... Relentless waves gnawed away at the tender flesh of the island, the scum from boats and ocean liners had poisoned the waters, and the flippant climate diverted the currents and along with them also the shoals of fish, draining the sea around Ouessant. At first, to avoid misfortune, all the doors on the

\footnotetext{
${ }^{6}$ The presiding god or spirit of a place [translator's note].
} 
houses were turned inwards and villagers desperately clung to the ground; but in these conditions nothing they did was enough to yield a good crop: after one bad harvest - a few years ago - followed by famine, and so all the inhabitants had decided to leave the island. "The sea had dried out". And the Daladiers, the Doumergues, the Rochillys returned to the mainland, their birthplace or sometimes a faraway land across the Ocean. A vision of incongruous beauty appeared in front of Claude.

On the edge of darkness, the moon emerged from behind the farthest end of the island giving off a phosphorus glow: the deserted town was full of frightening noises and devious shadows; revealing the bleakness, and perhaps the charm, of its wilderness.

The lighthouse keeper wandered through the maze that was the seafront. He knew it by heart: the dry-stone walls and the stone houses that in other places were known as "dommusi". He suffered the void of present, but the wistful feeling stirred by a vivid memory made him see everything as it once was, lively and busy under the sun. And so, he stumbled - or pretended to stumble - through the mass's nets left by the diurnal fishermen, he sought shelter in the shadows of the vendors' stalls along the alleyways, he spied on the caulkers as they waterproofed a small sailing ship. ${ }^{7}$

Then, as quickly as he had been overcome by this vision, the lighthouse keeper came back to his senses. He was hit by a strange impulse, it overtook his muscles, nerves and heart, suddenly he started to think that the pain, the abandonment, basically everything was necessary to give meaning to his lonely life: to make it harder, finally worthy of comparison with the feats of brave captains.

\footnotetext{
${ }^{7}$ Bilancella is a mall fishing boat equipped with a Latin sail mast and jib rod; used along the Sardinian and Spanish coasts for coral fishing [translator's note].
} 
VI.

One couldn't say with any certainty on what day in which year or in what era the lighthouse keeper made his journey to the beach of secrets. Along with the people, time had also left Ouessant: now the present and the past blurred together on that small island, the new and the ancient merged with no apparent distinction in the face of the abandoned town; and nature reigned over everything, and above nature hung a veil of mystery. A glimmer of truth or unreality sometimes pierced that veil.

Yet silence, and timeless oblivion were a fairly recent discovery for the island and its rocks, for its coasts and its wild sheer cliffs. Those same coasts had been a place for boats to land since the word 'history' has existed and in the past, they had known all kinds of visitors. Some - pirates flaunting the law, fierce and bloodthirsty marauders - came to make war and to pillage; and so, the islanders built that solid lighthouse to search the horizon. Many brought new religions: the Celts, the Romans with their pantheon of power and divinities, the Vikings and the Christians. The island's shores had become altars; they had burnt human sacrifices, offerings and then incense.

But more than kings and saints, more than explorers and conquerors, in Ouessant nature ran rife... Over the centuries Mother nature had enjoyed playing with humans, exciting and confusing them, guiding them for better or for worse towards shiny discoveries and aberrant ideas. In the stones and the ruins, in the traces of modern and ancient civilisations, the island was an encyclopaedia of utopia.

At the beginning, long-ago, Ouessant was an open-air temple, a site for obscure prehistoric rituals, adorned with mighty megalithic structures of which no trace was now left. Later on, when the Gauls had been conquered, the Romans turned it into a high security prison for the 
local kings and the leaders of riots and rebellions, a dismal and hideous prison but not devoid of all comforts.

Imperial architects built a magnificent villa in Croix des Vents; generations of slaves carved into the cliffs to sculpt out a safe landing place on the island. Tanks were dug to catch fish and stone cisterns to store the rainwater, since there was no natural spring on the island. Ouessant became a model of city planning and economic self-sufficiency, famous throughout the orbis romanus.

Crisis came to Ouessant as it did for the rest of Roman Empire. Its water cisterns became clogged, farms were abandoned, and further ruin removed any trace of settlement. A ruined, faded version of what it had once been, the island disappeared from the nautical charts. When it was re-discovered during the Barbarian era, its sleepiness didn't last long. The peace was short-lived before it was soon drowned in the mess of medieval life, crushed by evil intrigues and cruel atrocities. Vassals and royal officials followed each other in ruling Ouessant; the Francs arrived, and so did the Germanic peoples and then the Normans aboard their Drakkar ships. The island was impregnable, and its strategic location made it the place of merciless sieges and the stronghold of an unbendable resistance: in the colours of the landscape, in its acrid smells, in its very soul it absorbed frightening images of slaughter and devastation, of chilling screams and fearful cries, of young lives dragged forever into a hell of slavery and suffering. And then, when there were no longer reprisals to carry out, treasures to plunder or prisoners to put in chains, Ouessant regained its silence. To forget the horrors, it fell into a deep sleep, with no memory. And again, for centuries, it was only inhabited by the ocean winds. 
In their notebooks the Grand Tour travellers of the 1700s described the islet as somewhere wonderful and remote, an Arcadia where nature merged with the worn-out vestiges of an antediluvian civilisation. By a striking coincidence Ouessant combined the most refined speculations of the Enlightenment: it was an Arcadian place - the scene for a happy mixing of Nature and History; it was an archaic place - guarding ancestral, mysterious and wild rites throughout the ages.

During that era, once again, the dark spirit of the island took over. In 1768 the Bourbons of France attempted a bold social experiment.

An advisor to the crown, in love with Rousseau's naturalist ideas, convinced Louis XV to carry out an act of mercy and courage: an attempt to atone thieves, prostitutes and killers through the brutal purity of nature. Two hundred 'selected' were taken from the Crown's penitentiaries and left on the island to be guinea pigs for a novel punishment, but the experiment ended in disaster: left to their own devices and unbridled passion, devoid of rules or constraints, the convicts wreaked havoc. So, in 1771, they were taken back to the mainland.

A few years passed and new colonies arrived on the island: ever-migrating fishermen, farming families in desperate search for a piece of land after they had been evicted from the Breton coast at the outbreak of French Revolution. Thanks to them, after a century of hard work Ouessant had become what it was. That was until, the latest upheavals.

VII.

Beyond the village the island rose up from the coast stark and impervious. Its jagged ravines and pinnacles, points and inlets resembled baroque architecture. 
As you left the village, the main street became a winding road; an ancient mule track cut into the rockface. The inland landscape was narrower still: hillsides dropped straight into the sea, cut through into valleys as harsh as the life of those who had once farmed them.

The sunset gave its farewell with a final glow far in the distance and the night had begun to set in. It was an uncommonly calm night; the air was clear, and a crescent moon hung high in the sky.

The lighthouse keeper walked precariously along the cliff edge, along the ups and downs of the path, among thistles and gorse it was a stony terrain where only the olive trees could take root. He had to watch each step, not to put a foot wrong or to slip on loose gravel; he squinted into the dark trying to avoid anything dangerous under foot, his gaze switching relentlessly between the shore and the inland, searching for obstacles. Only once did he look backwards, towards a precise point, as if to make sure that something was happening in the usual place... Only, the glow from the lighthouse shone in the darkness: the powerful beam, miles away from the coast, reduced to a tiny gleam, flickering in the sky, no less remarkable than a willo'-the-wisp. There was no victory, no-one could win against the pitch-black Ocean, darkness splayed out in front of him and yet from the top of the cliff of Ouessant the lighthouse keeper took on the same near impossible challenge, like the dream of a fearless sailor or Ulysses' final voyage.

Not that night, of course. That night automated equipment performed the miracle of light in his place; and so did Ninetta, who had learnt over the years how to fill in for her husband so he could explore the island during the evenings.

Usually, Claude would go to the abandoned village, visiting it with the same respect as faithful believer at a shrine before retracing his steps as the fog set in or, lamp in hand, 
through the twists and turns of the dense darkness. But on this occasion, out of curiosity and necessity, he carried on.

He cautiously followed the bends and whims of the path, which lead him to the foot of a hill, which then rose into an uneven steep climb upwards. The lighthouse keeper climbed up, only stopping when he reached the top, from there he could see all the stars.

From the top of the hill, as if it were a ship deck, he stared into the vastness. He looked out at the alluring ominous Ocean, listened to the splash of the roaring waves as they chased one another to the black horizon; and then, shuddering as he heard a faint noise, wild and low, like a wild beast breathing in the distance.

In Claude's eyes the sea had now lost all its ability to connect, it was only a means to distance himself from the surrounding world. From a past, he could hardly recognize; from an elsewhere, which he continuously postponed his departure to.

Slowly but surely fear had crept into his solitude... Many years ago, he had chosen to come to Ouessant to test his life: to lash it, to humiliate it, to constrain it; but now, stripped of everything superfluous, his life frightfully resembled an abyss. Every time the lighthouse keeper thought about it, his teeth chattered with fear and there was a bitter taste in his mouth, something that resembled regret. Only the sea saved him then: at the cost of every other comfort, down below he had the sea, and the sea after all was greater than regret.

From the top of the hill, Claude measured the extent of his freedom: he climbed to the moon and came back to the ground, while the stars twinkled at the edge of his gaze.

They were all visible, hung like garlands over the dark sea. Like talons, stones fixed in the sky, like the bounty of a dream. 
Yet again the lighthouse keeper was dreaming. He saw fleets of ships out at sea and the boats of night fishermen incessantly trawling the coast; from afar he managed to hear the sound of the picks in the outdoor quarries, the rasping and the clean cuts of the shovels on the terraced slopes. Without really realizing it, he filled the void bit by bit with a mysterious familiarity. Down there, on the edge of the earth, in the night flooded by the moonlight, in the drowning fields and the flakes of dreams amongst the olives, his heart took root.

\section{VIII}

The mystery beach was hidden from view a treasure chest jealously guarded by time. He came upon it suddenly, counting out the exact number of steps and brave moves through the brambles, as if repeating a magic formula. And behind a screen of black cliffs, the spell unfolded ...

A long wide beach built into a hollow of the rocky wall, sculpted out by centuries of heavy sea; draped dunes covered in shrubs and rock roses, a low bank awash with the scents of the lavender and rosemary bushes dotted around. One step off the beaten path and suddenly Claude was transported to another place, to another time: the howling whirlpools became mirror-like crystalline water, the din of the waves fell away and the island stood wrapped in a surreal silence, as if it had sunk into his very heart.

\section{A black heart...}

Right in the middle of the beach the bare skeleton of a 'ring' appeared: a group of basalt steles in concentric circles around a large mound. It was a sacred place, a monument of some Druidic religion, rather common in the North Atlantic area but nonetheless impressive in size and architectural perfection. The central altar, now stripped of its earthen coating and reduced to the shape of a massive dolmen, prayers once rose to the stars and the sky. On that altar, as 
rituals evolved, human and animal sacrifices burned, then fires of bark and roots, then at the very end incense. Eerie in its grandeur, the monument evoked ghosts of brutal vitality, times of darkness and times of light, a fragile coexistence of myth and uncertain reason.

But the ring wasn't the only treasure on the beach. Close to the sacred area, the length of the cove, there were remnants of more recent architecture: wells and canals that held secret underwater springs, large tanks that collected the quiet flow of the surf. Inside one of these caves lay the island's latest wonder. It seemed to be a large dark mass, a mountain crumbled on the sand, blocking the view to the far end of the bay. As he descended the sheep-track on the right side of the beach, the lighthouse keeper noticed it immediately. He instantly dug in his heels and stopped where he was, metres from the giant. His heart began beating incredibly fast. He looked at the colossal body with its asymmetrical head, its mouth half-open, its blade-like teeth, its uneven lopsided eyes and, above the brow, the large s-shaped blowhole.

It was a sperm whale: the lighthouse keeper knew exactly what this creature was.

The largest living mammal, the largest toothed being. But for him, if possible, it was something greater.

From the depths of his heart, he greeted the wonder that was this sleeping creature: a divine visitor, the sign in the sky that he had been waiting for all these years.

Was this the messenger? Was it the one sent to tell him that his wait was over? That it was time for him to out to sea again, to go beyond the edge of the earth? "Perhaps", he thought out loud. "Perhaps" he repeated in a whisper. He knew that if you say it aloud, it might not come true.

At the moment the messenger was stiff and lethargic, resembling a rock more than a creature of flesh and bone; from its large s-shaped blowhole it dripped the last few drops of water. 
Because it breathed fresh air, it could have lived like that forever, but the lack of the water became an endless agony. The pool collected in the tank barely covered its belly.

Dried out by the sun, he was becoming dehydrated, its colossal body let off a heady smell of the deep but not a sign of life. Perhaps it was hallucinating, lost somewhere behind the demons screaming in the clutches of its dreams.

The lighthouse keeper could almost see it; he was following it. He would keep following till the end of the path, until the creature came to its senses and opened its eyes. He would follow it forever.

But every moment he lingered in this dream, any further hesitation, would mean certain death for the sperm whale.

The sea was calm in the cove and the water shone brightly under the moonlight, as if it were covered in oil. But somewhere offshore, just below the surface, there was movement, a swirling of fins and jaws, the slope of their backs were like hills.

The pod feverishly wondered about the fate of the missing member. They had remained there, hoping that he would make it back by himself: none of them would leave to search for him; they followed the cruel unerring law of nature and the repeated teaching of experience. They could wait for a day, perhaps two, that was all the leniency they could allow.

Claude understood that he needed to act, as chance decides for the undecided. Suddenly he overcame his surprise and embarrassment and he rushed over to the giant not knowing what to do, driven by a sense of commonality, a certain kind of familiarity. He pressed on its smooth hard skin, teasing it, trying to cause any reaction, then he gathered water in his hands and poured it over the whale's snout. He wasn't afraid of the wild power that could erupt from that wondrous being. More than its life, its death now frightened him.

For a long time, the lighthouse keeper carried on repeating these same actions, each time with more vigorously. At last, after one more try, something happened. 
Out of annoyance, perhaps, rather than relief, the sperm whale shuddered. It let out a feeble spray of water from its blowhole. It opened its huge eyes, one after the other, then shutting them again, then it opened its eyes more intently this time. The night in the bay now resembled the underwater half-light and the sperm whale saw clearly that the man was one of theirs, one of those that had left the sea on the back of the Grey Giant, hoisting themselves into the world of air.

The man also recognised a part of himself in the creature: in the depths of its wide eyes, he read the story of the abyss; he a peaceful feeling came over him, like a memory from a previous life, followed by a primitive instinct, a burning desire to wander. Even more than birds are born to fly, or fish are to swim, he embodied the lithe and powerful shape of that creature.

All of a sudden, abandoning its hermit-like appearance, Ouessant seemed like a remote paradise on earth, where the first scene of humanity was re-enacted. They were both there, one in front of the other, the lord of the world and the largest creature under the sky, once again they held hands.

The sperm whale couldn't believe it. From the waiting room of the marine after world it found itself transported to the doorstep of a new life. The tide rose and so did the water in the basin, now covering its hips and its tail, the whale could finally taste salvation.

As for him, the lighthouse keeper was living in a dream. He kept looking at the creature's clumsy head, its serrated dorsal fin and its tail as large as a tree canopy. He stared at its huge eyes trying to catch any movement, a glimmer of emotion; but the big blue eyes remained with that same guarded and contemplative expression.

And then, it moved... Something began to spin in the pupils of the giant, in a hypnotic rhythm, in ever wider, ever deeper circles. The lighthouse keeper got lost staring in them. 
At first, he saw a blurred image but gradually it became clearer, and he was sucked into the vision. In the beginning he could not place where he was, as if he had accidentally plunged into someone else's dream; but then he noticed something familiar, it was something he had imagined many a time. His strength, his bizarre courage, his determination to stay faithful to himself, against all odds: these things were represented in a symbol. A cliff in the middle of the Ocean, flooded with sunlight; a tip of rock emerging from a bed of silvery fireflies. Nothing terrible in itself... But the whole scene had something sinister about it, something oppressive, more a threat than a concrete danger.

The water surrounding the rock was incredibly clear and salty, it seemed white hot. It gurgled and boiled, releasing a cloud of dense gloomy vapour into the air, as if it were coming from the mouth of hell itself. Alone in the face of these gigantic forces of nature, the rock mustered a delicate and desperate resistance, it shielded the lighthouse keeper's dream; kept it safe from the waves, clenched in its fist, his heart reduced to a single atom.

A moment later the scene began to change. As the lighthouse keeper's gaze penetrated the dense mystery, the compact surface of the sea shattered into many tiny streams - twisting and turning, they shone; tongues of fire flickering, crackling, attacking the bare rock. As the turmoil built, and the rhythm of the waves grew violent, the more the rock resembled a bastion.

And beyond, just beyond a frightful spectacle occurred. The Ocean in all its entirety fell into the abyss, it sank down the edge of the world. Everything was simply lost: faith vanished, confused with doubt, the stricken sky rolled to pieces, from the bottom of the fall, in the dark, a ghastly inhuman howl was heard. Just like the drawings on the ancient nautical chart, there were monsters beyond. The lighthouse keeper was watching petrified. He opened and closed 
his mouth, but nothing came out; he tried to calm down, breathing in time with the tide. Sweetness and horror, sweetness born out of horror: this is what he saw.

He barely untangled himself from the coils of that vision (without realizing it, just wishing it would happen soon) and when he had been released- or perhaps not - he glimpsed a light flickering through the sky, a spark of revelation.

In that exact moment Claude Valery knew that he would never leave. From then and forever he would live out the rest of his life in Ouessant.

He staggered about. A sense of emptiness overcame him.

Nothingness or endlessness, there was only space in his life for this. Away from the excess, far from the extremes, there was no life: a pale copy, if anything, a pitiful farce marked with regret, distorted by the madness of failure. And he, needless to deny it, he had failed.

All traces of his pride fell away. Like fallen idols, the god of the edge of the world and the last Ulysses left their place by the moon and the endless stars in the night sky. His certainty of being the only one slowly sank into the dark sea, leaving no trail, no trace of solace. Empty nothingness.

Strangely the sperm whale seemed to make use of such despair. It appeared to be comforted, it drew strength from it... Manoeuvring itself with tail strokes and its pectoral fins, it broke free from the tank and made it out into the bay, in search of a spot to dive down. The tide was getting high, and it could almost touch salvation.

In the pitch-black tide of the lighthouse keeper's mind, a thought floated about, which he dismissed at first until he could no longer ignore it. It was late, too late, and Ninetta was waiting for him, alone in the lighthouse. He had to leave the creature to its fate and take the road back home. He had succeeded in his task: now he just had to worry about himself and how he would live with the bittersweet memory of what he had witnessed. 
As he pondered this, the wait was suddenly broken by the sperm whale diving down. A crater opened up in the bay and the sea foam splashed into the sky. In a matter of moments, its endless body became one with the tide.

The lighthouse keeper was walking back distractedly. He was still angry, and resentful, and he hastily turned away from the betrayal of the messenger. He began walking again, pierced by an irreparable sense of loss.

A quiet voice, a submerged voice, kept whispering in his ear. "Turn around" it said persuasively. "Turn around again", it insisted.

The lighthouse keeper tried to ignore it, as he had before. He thought only of Ninetta, the lighthouse, the way back and - surprisingly - as he thought of getting back to the lighthouse, it was returning home.

He almost cursed.

Ruthless and subtle, life had got the better of him... It had crept in surreptitiously and deceptively - he couldn't remember how - during the night it had worked its way into the folds of his sleep and infected him. Now he was like everyone else: no wish to get lost, one step away from infinity yet unable to touch it.

But he no longer felt resentment. Instead, he felt joyful, sated by that incredible story, and happy to have somewhere and someone to share it with. He turned.

From the intimate depths of the sea the sperm whale rose up fearlessly. It came out of the water, grey under the moonlight, farewelling him with its spray. And he answered. 


\section{A Shade of Blue}

"If you think about it, it seems impossible to explain someone's life and all the things it contains, how they happen, why they happen and why they happen right then. But it isn't difficult, no more difficult than explaining whatever other part of the world. You just need to find the right way, the right metaphor. My life can be explained with the sea".

Vittorio Mazza, "De Sica" to his friends, was the only customer still at the restaurant bar at closing. He sits there from midday in his usual spot, the table in the corner of the terrace, and he smokes, facing the sea. With his cheerful expression, his mischievous moustache and his hair coiffed back and lacquered, he looks just like the sergeant from 'Pane, amore e fantasia' $^{8}$. He smokes a lot; it must be his tenth cigarette since he arrived. The last of his 'friends' had left half an hour ago. He had come to pay for his beer at the bar, but then we heard De Sica's voice: “Leave it, please, leave it. I'll do it later... and you, Gigì, do not take a cent from that gentleman". As usual, I refused to let him pay and after some resistance he gave up.

Letting De Sica pay is worthwhile: you'd always get a rather generous tip. And if sometimes he asks you to "put it on his account" because he doesn't have the cash, well so be it.

In reality he doesn't have any sort of account, but there has never been a time that he didn't pay what he owed. He could well forget to pay his monthly bill for the apartment building or the telephone bill but forgetting the tab at the bar was out of the question.

Vittorio Mazza is an actor. It may be more correct to say he 'was', seeing has he hasn't had a job for the last ten years. He was the 'eye candy' and the passing of time plays hell with eye

\footnotetext{
${ }^{8}$ Bread, Love and Dreams - 1953 film starring Vittorio De Sica [translator's note].
} 
candy. And if you add that to the fact that De Sica is a presumptuous pain in the ass and a hypochondriac, the picture is complete.

Many years ago, he had made a film with Fellini: "Giulietta degli spiriti” I believe it was called. He played the spirit; he danced in tights, pale as death and covered by a veil. Two minutes in total... Maybe he told a joke.

I had seen the film, but to be honest I hadn't recognised De Sica. If he hadn't shown me the original clapper board for the scene and a photo that showed him smiling as he hugged the director, I would have said that the man in tights wasn't him.

For De Sica — needless to say — the truth was quite different: his work with Fellini was merely the shining pearl of his successful career. After putting in the hard yards for some years, he made it to the stage and remained there for twenty years or so: he had been part of one of the most well renowned theatre companies, he had sent the crowds into a frenzy, he had lived 'the splendours and pleasures of La Dolce Vita'. At the time, he'd lived in Rome, in the 'artists' district', close to Sordi and Mastroianni, amongst the writers, poets, femme fatales and the camera wizards.... Now he lives in the countryside.

Since he'd come back "to take care of his sick mother", almost ten years ago, he has been a regular guest at my bar. His mother spends all day with the nurse, and he spends his day here, thinking his thoughts by the sea.

"That's the job of an actor, Gigì... one day they call you and the next they have forgotten you. It could be days and days, until the phone rings again... It is the actor's job: you need to get used to emptiness, to idleness, to solitude... Only your thoughts don't leave you: your thoughts are your most trustworthy companions".

Even if it had been ten years since the last time, De Sica was convinced that the phone would ring again. And he waits here, in solitary quiet, going through his "thoughts" in front of the sea. 
If they really want him, they'll find him.

The bar is always full of film people in the morning. Lowlifes, destitute, lost souls: all the lazy buggers in town meet here.

Honestly, I can't explain this place's luck. There isn't really anything charming about it... the counter, the tables outside and all the furniture have been the same for the last twenty years, the options are limited and the service leaves much to be desired.

There isn't anything attractive about it apart from the sea. The sea is a blinding vista, after the dingy streets and the dark alleys. De Sica arrives at the bar around ten without any hurry. Dressed elegantly, in a rather old-fashioned manner, with a brash walk, that was immediately recognizable amongst that sort of crowd.

You could tell that he was made from a different mould, an entirely different species of man... He takes his seat in the corner of the deck - 'his' corner - and he starts to drum his fingers on the table. Every so often he will cough to attract attention. He seemed confused, out of place. And a moment later, there he was at the table, surrounded by a group of drunks, talking about his own business with such sincere enthusiasm and the greatest confidence.

It makes me think that he would do anything to please them: if they asked him to walk on his hands then he probably would.

When the enthusiasm of the story grants him a moment of respite, I approach to take his order.

"Good morning, don Vittorio".

I call him 'don' because it immediately puts him in a good mood: anyone who calls him 'don Vittorio' is already half-way there to becoming his friend. He relishes the attention.

"My dear Gigino... the usual for me and whatever these gentlemen want".

The 'usual' would be a glass of barrel aged whiskey. A special treat. 
I barely pick up the grunts coming from the louts sat around the table. Just as I turn towards the counter, De Sica stops me: "Just one thing, Gigì: not too hot or too cold ... the doctor found an ulcer."

When it wasn't an ulcer, it was gastritis, irritable bowel or heart palpitations... If you believe him, De Sica had suffered all possible illnesses: only in the time that I have known him, he has survived two heart attacks and emphysema in his lungs. He must have a body of iron or rather it's a miracle; it's true that he never stops pleading to the saints to continue to protect him for any future health problems he may have.

Everyone thinks that he has an imaginary illness. He is someone that in reality is very healthy, but he needs to have something to cry about, to feel like he could 'keel over' at any moment.

He certainly likes to be at centre of attention. To attract looks, to be talked about, to feel people's eyes on him. That is the reason he became an actor. This is the secret of the trade that he talks about: this and nothing else. Even if he hides behind words such as 'talent', 'charisma' and 'the thrills of the stage'.

For the entire morning De Sica keeps the table captive with his story of his life transformed into a show. His glass of whiskey gets abandoned and he loses track of time, he gives himself to the audience entirely. Between the jokes, anecdotes and the dramatic back story, it can take hours.

Then just before the restaurant closes for the afternoon, as if at someone's order, the customers clear out. One after the other his 'friends' leave to eat at some dive or at the church soup kitchen or best case they go home to have insults thrown at them by an exasperated wife. 
When he realizes that he is alone, De Sica starts poetic discussions. He talks loudly so that he can be heard at the counter from out on deck and every so often he asks questions, in the hopes that it would bring me to his table. He knows that I don't usually go home for lunch and he wouldn't know what to do with himself at home. Then he stages one of many of his tried and true jokes and provocations, voicing complex thoughts or charming words ... I've been going along with it for some time: at two I close the doors and I leave the entire deck to him. So, while I wander around cleaning up, De Sica lights a cigarette and watches out at the sea. And the two of them, he and the sea, are the perfect image of idleness.

"My life can be explained by the sea."

Only after the doors of the bar have closed and he is sure that nobody apart from me can hear him, only then does De Sica start to talk about the sea. It is a rare topic of conversion, reserved for the days of 'greater inspiration'. This is not the usual sort of conversation that De Sica strikes up to just kill time: when he speaks about the sea, don Vittorio talks about it seriously, as if it is the most serious thing in his life.

"Looking at the sea is a bit like looking at the audience from the stage. It's like looking at thousands of faces without seeing anybody... The edges blur, features become confused, they overlap, and, in the end, you are left with one anonymous face. The face of everyone and no one..."

“... Success too, Gigì... isn’t success like a storm at sea? It begins mysteriously, a tiny, perfect and invisible sequence of events that sweeps over everything. And then one day it ends, slowly without remedy; when the wind changes, when the clouds have squeezed out their last drop of rain". 
He can go on for hours... over the years he had come up with an infinite number of connections between his life and the sea. He stops. He needs a cigarette. He pulls one out of the packet on the table and lights the cigarette covering it with his hand, like some American actors do.

He inhales, waits...

... a long theatrical pause.

Then he starts again.

"The sea is made up of many things that are in inside and outside of us... Everyone can look at the sea; the point is, what do they see? The others look at the waves, the tide lines, a flock of birds and they see signs, lines in the water, migrations. This is what they see. But I see joy and desperation, trust, loyalty, courage. Like a man, Gigì, like in life".

He takes another drag from the cigarette, just enough time to be pleased with himself.

"I could never have worked at a bank. Teachers, lawyers, and bank clerks are people without imagination". He exaggerates on purpose, hoping to draw me into the conversion.

"I think, teachers, lawyers and bank clerks are respectable people. Perhaps they don't pay too much attention to the sea... But who can blame them? With all that the things they have to do...".

“Do... Do... Gigì, does one only do what one is seen doing? Tell me... Couldn't it be that someone does things secretly, without making themselves seen?

"But of course! I know a dozen people that do things secretly, silent projects... but usually these things that they are hiding are not good."

Some things you do with your hands can be bad... But the point is: you do things with your hands, it's true, but you also do things with your head. And who's going to see someone secretly thinking? Take me, for example: could you say that I am always doing something, 
that I am always thinking something, and that I don't sleep at all since I live in a perpetual, florid radiation of thoughts?"

"But what's that got to do with it, don Vitto'! If we count our thoughts, then nobody is ever doing nothing. And also, don Vitto', these thoughts... Something so slight and intangible. Where are those thoughts? And who are they for?"

De Sica laughs. He laughs and then he sighs. 'I'm sorry ... I wasn't paying attention... You say 'thoughts': the day's take, bills and fees, appointments, deadlines, projects... No, no, Gigì, I'm talking about the sky, the stars, the moon, the sea. You were right, Gigì, teachers don't notice the sea...

The sea, the sky, the moon and the stars don't exist: they are mere thoughts. The thoughts of someone like me, who has nothing to do. But think about it, Gigì, those thoughts are not so intangible: they are right here, all around us... And if you too look at the sky every now and then, and perhaps take a moment to think - just for the sake of it, for no other reason, just because - that's why you run into those thoughts".

I'm not sure I understand exactly what he's saying.

"Thoughts are the sky, the moon and the stars" ... "The sea is made up of many things, inside and outside of us" ... I recall during the evenings, he would walk back and forth on the sea front, running his hand along rail to the lookout. Then suddenly he stops and gestures towards the sea as if he is asking it to be silent...

He is crazy - so people, well off people, say - no crazier than me, all things considered, I stare at the walls and talk to my model sailboats after closing the restaurant. Instead, De Sica, walks back and forth along the seafront. Aimlessly, for hours. Then he suddenly stops, in protest as if asking the sea to be silent... maybe he wants to hush something else. 
De Sica and I are two very different types of men. For him to be right I would have to acknowledge that I had done everything in life wrong, and him too. But that was too much to ask from the both of us.

We are not alike, and we never will be, because of this we look at each other with mistrust. He knows that beyond the appearances, beyond the courtesies, the respect and the kind gestures, I consider him a 'failure'. A peculiar person that lives in an illusion...

He can read it on my face. And he feels the need to justify his life.

"I consider myself a fortunate guy, Gigì: I have done exactly what I wanted to do, what I was born to do. There are not many people that can say the same... And what I have done is enough for me. I have had fame, success, money and women, and now it's enough to have many great memories and affection from friends."

The 'friends' that De Sica refers to are no more than cheap flattery, far poorer than him, willing to say just about anything to get a free drink...

It's so obvious they are pretending; they don't even listen to what he says, and it is just as surprising that De Sica doesn't notice anything... Or maybe he does notice, and he too pretends.

"Around town people say that my friends take advantage of me; nobody has understood how things really are... Those who take advantage of me have yet to be born. If anything, it's me taking advantage of them. I offer them spirits or a beer and meanwhile I steal their time. And I fill their heads with my stories. I take their mannerisms and their words and use them in my daydreams ... Every real artist is a thief". 
Every now and then even De Sica crashes into reality. It is something so unusual that it is almost frightening.

"Everything happens according to the script, Gigì... One day you will go down the street and you won't recognise anyone anymore. Slowly but surely the lights begin to fade until the stage is dark. The audience gets up, the room empties, and the excitement just survives the show. There isn't anything sadder than when the stalls are deserted before the end of the show. Have you got any idea of how many people were at my last show, two years ago? Twenty people, twenty poor sods that grumbled, stamped their feet and didn't even know where they were... There is nothing to be done Gigì: I was born under a bad omen.”

Told by him, the tale of De Sica is one of a great passion, greater than any hindrance fate could throw at him. But when he is sad the plot changes, the story becomes tragic and, in the end, fate wins. When he is sad De Sica is no longer himself. He becomes just like any lawyer or professor, one with no imagination, someone who sees no more and no less than what exists. When he is sad, De Sica becomes like me. Then looking at him is like looking in a mirror, and I too become sad ... Maybe that's why; to protect myself, that's why I console him in any way possible.

'No, don Vitto', it's not like that... It's just a phase: it will pass... You're still young, full of energy, and you always have your women..."

"What women Gigì... who still thinks about women... At this point, I'm passed the age". His tone was serious, but his gaze has been fixed on sunbathers lying on the beach, you see hope is the last thing to die.

"Listen here, Gigì... that woman over there, do you see her... Do you think she is looking at me?" 
'I didn't notice don Vitto'... But if you say she is, then certainly she is. Who knows more than you about these sorts of things?":

"Listen, Gigì, can you get a little closer so you can hear what her name is, where she lives... tell her I sent you".

“And can't you go to her yourself?"

“I can’t, Gigì. You know, in my position... Could you imagine the great Gassman approaching a sunbather on the beach?"

In situations like this, for blessed be the customer, even the most undesirable, who saves me from that embarrassment.

Otherwise, I don't have another option: It will end with me going up to the young lady and then coming back to De Sica with a fake name and address. Until he tries to lure his next prey.

In his youth don Vittorio had been an incredible lover to ever changing, mysterious and unsuspecting women. It was even said by not very reliable sources, his friends' girlfriends. He would gloss over the names and the details, as true gentleman does, though he would hint at somethings with his mischievous smile. It was not hard for me to believe that he had been so popular... His charming looks, his refined ways and his untiring dedication to the pleasures of life.

These are the things that no woman would be able to resist. If I think about it, I'm not even sure about my own mother....

But even if she had (and that couldn't be possible...), he would never let a word slip. He doesn't like talking about the adventures of his life: he keeps his women, every single one, to 
himself, guarded jealously in a sanctuary of sighs and perfume. “They have been my body's companions, and now they are my soul's companion."

Sometimes I try to get him talking about the topic.

"Don Vitto', after so many women, how is it possible that you never married?"

He doesn't give anything away. "What questions, Gigì... can you imprison the sea? Can you stop the sea? The sea is free". Free to tease the maids and the swimmers without the fear of complications. As if it were only a game for children.

"I have had so many women in my life. But I could never choose one. How could I have chosen one? I belong to them all".

You can hear a mix of pride and melancholy in his voice, and you can see him right there, in a gondola, disappearing into the mists of the canals of Venice - his cloak fluttering in the wind and the languid glance of a Casanova.

Talking about women, imagining them, pursuing them even if only for fun, perks him up. An innocent enthusiasm takes hold of him: his eyes, his smile, and little by little his whole face lights up. "It's as though the sun comes out from behind the clouds".

He doesn't say this by chance. For De Sica it is the most obvious comparison in the world that prompted him to return to the core of his philosophy.

"It's simple Gigì. Our lives - every life actually - is an imitation of the sun. And of the sky, the sea, of all the world... All the world - things, shapes, colours - everything is full of emotions; on the other hand, every life also has a shape and a colour".

There are days when I like to join in with his games... "And what colour is your life don Vitto'?"

"A shade of blue. Like the sea".

He answers at once. Only afterwards does he stop to think. 
"I don’t know exactly, Gigì... just a shade of blue".

After countless times explaining the metaphor of his life, De Sica has become one with the sea. The sea is his favourite pastime, and so much more: he needs it to fill the void and make sense of things. He only needs to look at the sea, bright and solid, it's perfect blue, and suddenly the ugliness, the contradictions, the signs of a past bitterness all disappear from his life. In truth the sea is the metaphor of his life. Not of how it was or how it is now but of how he would have wanted it to be.

"While watching the sea I found a diamond in the sand: in a hundred years' time, when I die, I'll have this written on my gravestone ... What do you think Gigì?"

I think that the truth of a man doesn't lie in what he is but in what he would like to be. If De Sica were honest enough to admit his miseries, he could have that written on his tomb. But he's deaf to that idea...

"The only misery I know is getting up in the morning and knowing everything that will happen until it's time to go to bed. The only real misery is being a slave to reality, killing imagination, believing that only what you see exists".

"I know another one. Getting by on dreams at the expense of those who have to live in real life... And claiming it's the most normal thing in the world, nearly a natural right of the chosen..."

Don Vittorio shakes his head: "once artists were a blessing. They were the men closest to the gods, so close they could touch them... When a show was on the whole world stopped: everyone stopped whatever they were doing and rushed to the theatre to participate in the ritual and learn something new about life and people". "What times are we talking about, don Vitto'?" 
"A long time ago, Gigì, too long ago... And who thinks about those times anymore? Between now and then too many centuries of the land and hard work have passed".

De Sica detests the word 'work', and especially the way it rolls off well-off people's tongues. He speaks of work as if it were an illness, as if he were speaking about the plague.

As for him, he was a staunch lover of the comfortable life; although at times he would force himself to get up at an ungodly hour to "clear out" mullet fish on the rough seas. "You have to do it, Gigì... every now and then it's good for you to breathe the morning air". Anyway he has the whole afternoon and the evening to relax...

De Sica had fishing in his blood. He was proud to be from a fishing family, "three generations of sailors"; though he had never been to sea. He fished down by the harbour; he would set himself up on the breakwater behind the pier. He didn't have that much patience. As soon as he felt like he was getting nowhere, he would pick up his stuff and go to the jetty to spy on the affairs of the fishermen, the actual fishermen. For them don Vittorio feels some sort of veneration. In contrast to the "uneducated farmers", who have put their neighbours on the cross with the absurd demands of their ignorance, the fishermen are the good conscience of the world. For De Sica they represent freedom. The enthusiasm to try and the risk of staying out under the sky; and one day they brought back all we know, bringing it with nets to the surface from some mysterious submerged continent.

"To the stern", "To the prow": the fishermen shout out commands directing the boats that are setting off... De Sica knows all the slang. At a distance, on the pier, he watches as they leave with a look of someone that knows everything about the sea.

At some point - always the same in that first, deserted afternoon - De Sica gives up on me. He stops talking and he concentrates only on the sea, in perfect silence, to hear the sound of the water and to relish the vibrant afternoon blue. 
It is the silence, this is what really fascinates me about De Sica: he is silent, completely absorbed with his thoughts and that intense look on his face that mean any number of things. I don't ever want to know what he is really thinking, with the risk of finding out that he is only thinking of one particular thing, something mundane perhaps, that has no mystery. I almost regret cleaning. At least I try to be quiet, as if I am walking on glass, avoiding any noises that could disturb my guest. Suddenly he breaks the silence. He calls me over.

“Listen, Gigì, come listen".

He asks me to sit close to him, "as comfortable as possible", and he begins to read from a page.

"A man and a woman walk on the surface of the water hand in hand. Lightly, effortlessly, almost miraculously. And miraculously they love each other with their chests to the wind, heartless. Their hearts - their heavy hearts - lie at the bottom of the sea".

From the day I met him - at least ten years ago - De Sica has been writing a story, somewhere between a novel and a play, the story of a travelling salesman who falls in love with a billboard painter: "A little Kafka and a little absurdist theatre".

He has written almost all of it. It's been missing the end, for ten years... He must have read me hundreds of possible versions, sometimes he would change just one word, he couldn't settle on a definitive choice. It is a delicate matter after all.

"The beginning and the end are the only things that really matter in a story, whatever happens in the middle is often too difficult to understand".

After five, a couple at a time, his 'friends' return to the bar and De Sica repeats the morning show. He finishes telling the story of the time he performed at the Sistina, of the time when 
even the great Gassman praised him, and the excitement of meeting Visconti and Pasolini in person.

Until it becomes that time, just after the sunsets, when the light only remains on the edge of the clouds and the evening mirrors exactly how he feels. At that moment De Sica stops whatever he may be doing... He stops a story in the middle, puts out his cigarette, sends his friends away, and looks up at the sky again, the sea and the blue that's becoming ever more vague - "bright and blurred like Monet's impression sunrise".

He stays like this for a few minutes, motionless, thinking of nothing. And finally, when the sky has faded, and the sea is colourless, he gets up from his spot in the corner, says goodbye to everyone and leaves. He returns to the daydream that is his world; but not before breathing in, "from the depths of the air", something only he knows. 


\section{The Idol}

An earlier version of this story has been published in the Journal of Italian Translation, Volume XV, Number 2, Fall 2020.

The beaten earth of the pitch no longer absorbs water. It becomes a bog after a little rain, and it stays wet for days: a sickly grey muddy mess that no sun can really heal.

At the Acerra football pitch the car park is nothing but dirt. There's been no grass for ten years now: the wheels of a hundred cars - big flashy cars and clunkers - have turned it into Atilla's battleground. They are parked randomly around the pitch, in lines and circles, as if attempting to usurp the land. The cars of cocky club presidents, downgraded coaches, players who had to put their dreams on hold, blue collar wages and a piercing clamour of the Azteca stadium in their head. The players dive into the changing rooms, cursing the mud and come out dressed in bright red betting on how long it will take for them to get dirty. They enter the pitch, if you can call it that, and the pitch is just an extension of the car park: same old dirt - beaten down in the box and mounded up around the goals -, patches of grass on both sides, proof that grass still manages to grow. There is no trace of grass however in the car park (that's why they call it "the car park") yet this is where the most unlikely event in the world unfolds. For the last fifteen minutes, a team in blue has been warming up in a circle. In the cold, under the leaden sky, they perform a ritual with great professionalism. Two tall men, a goalkeeper dressed in a dark jersey, six of average height, three bald men, three short and two with curly hair. The shirt is just ever so slightly altered: for an informal game they can't wear the official match sky-blue. But the way they are training, the toned muscles and the shiny new boots leave no doubt.

S.S.C. Napoli, as the poster proclaimed.

Faces that nobody recognizes. Old legends and reserves: two tall, three bald, three short, two with curly hair. No. One with curly hair and... the Idol.

You rub your eyes and count again. One tall and bald, one short, one average and curly haired 
and... the Idol.

He moves with the grace of a dancer, the precision of a violinist tuning his instrument. Tall he is not; he is not handsome, but he shines: under a nest of curls is a faultless image of power. A paragon of perfection. Perfect, as a sphere. He drops to his knees and then explodes upward, he bends and twists, loosening his muscles, his legs and joints, stretching out his arms. And this is already a show in itself.

A silent intuition, which wins out over all other distractions, begins to draw the spectators. A hope against all odds, and then an unbelievable truth, spreading quickly by word of mouth, as extraordinary as it is inexplicable. Acerra is Pulcinella's hometown. The town of 'pyroclastic ruins', the volcanic flows which turn to black earth as they touch the ground. The ground scarred by cinders. A town of badly dressed people in camel overcoats and children looking like miniature adults, paraded around as if they were little saints sent out to collect money like shameless angels.

On the stands, which in fact is only one stand amongst the state houses and construction sites, there is a crowd of about ten thousand. There are too many. Those who don't fit pile up behind the home goal, trying to spot Maradona's face as he runs forward.

They rub their eyes in disbelief. They look to the children to try to make sense of it all. It seems like the start of a fantastical dream, a fable made up by a small-town journalist; instead it is entirely true.

The Idol comes on to the pitch. He poses for the ritual photos, kisses children, waves at the crowd. He never smiles.

He looks around and lowers his head. Glances briefly around.

He breathes and stomps his feet, testing out the pitch.

He's serious.

He slips, misses a pass and returns to the mid field dejected. He leaves his opponents behind 
and delivers a wonderful assist to allow the easiest goal in the world.

"You alone!", shout the intruders as they sneak down onto the side-lines, "You alone!". "Vattenne ind'a porta sulo tu!". It doesn't matter that the reds are home team, that the black and green goalkeeper feels the despair that any goalkeeper would.

"Into the goal, alone".

He cheekily plays about on the wing, drives two players crazy, he lobs the ball to the centreforward who passes it back, he scores with a flying kick and falls to the ground on his arse. He ends up in the mud. He's annoyed. He frowns. Maybe no, slowly he begins to understand why he is there. His face has the shadow of one who needs to atone.

Atone for the night life and the attentions of the strange 'groupies' who see to his every need in return for a photo with 'someone important' or some odd invitation to either a tacky wedding or a christening; atone for the vices which make a mockery of the simple ignorance of his childhood pitches in Lanus.

He ran off overseas leaving his conscience behind. In this moment, he begins to understand. In the muffled lap of suspicion, he's playing another game.

An hour and a half of rapture. The Idol dances in the mud and is covered with a different kind of dirt. He keeps afloat by the force of his legs and yet his heart is locked in a drifting hold. For all the others he's a backup sun.

It is drizzling. The crowd yells and chants. They dance under the rain like Pulcinella himself. Then the referee, hunched over like an accountant, blows the final whistle. The players return to the changing rooms: that is, they cross behind the goal and through the flower beds into a concrete shed. It's likely there will be no hot water, but nobody has the guts to admit it.

A man in camel overcoat moves closer to the number nine in the blue shirt, and mutters in his ear, under the mass of curly wet hair. "Twenty million", he whispers excitedly. For the poor little boy and his delicate operation, twenty million. They laugh. 
But the Idol doesn't laugh. He brushes against people, accepts hugs and pushes on past them; he needs fresh air, space. From his home on a cloud, he has descended down to re-experience hell.

His arse hurts from the impact of the hard ground. He puffs his chest out and is a child again, in the outskirts of Buenos Aires. He goes to get some fresh air and thinks about the beaten pitch that no longer absorbs the water, the leather-like, hopeless disillusion.

No sun, they say, can heal it. 


\section{Beco}

An earlier version of this story has been published in The Journal of Italian Translation, Volume XV, Number 1, Spring 2020.

The men in orange jumpsuits were doing somersaults. The loudest of screams rose from bleachers, a thunderous noise that shook the earth.

The grandstands, like the packed shacks on the hills of Sao Paulo, looked like a hellish bedlam. A nearly vertical wall of people, a hive of ants heaving against the railings, a trembling image that seemed compact, a whirlwind inside a cloud. Tattered men embraced, clambering on top of one another into human pyramids — acrobatic grape like formations, where each person was a grape worth ten Brazilian reals. Every man in that picture was worth the price of the ticket. His humanity consisted of nothing else. The ticket and that obscene, sterile joy for joy's sake that devoured itself with ravenous bites.

"God Ayrton". The men in orange jumpsuits tumbled on the grass near the curb, alongside the wall of the box, throughout the stretch that led to the finishing line. It had been three days since they had become race officials and they trembled - in a grand display of restraint - to feign impartiality. Up to the last lap his muscles twitched under the skin, a step away from truth, still uncertain, still revocable. "Ayrton's gear box broke" the news spread from post to post along the track. For the last six laps he had been racing in sixth gear: someone close to the box picked up the radio transmission and passed the message to the others. But how can you race in sixth gear? Only in sixth gear, I'm telling you... An aura of legend was felt around the circuit.

And then Senna reached the "Ferradura" curve, passed through the chicane, on to the parabolica, all the way to the finishing line.

They followed him like many acrobats: brimming with emotions, they performed stunts as they celebrated his triumph. 
The hero let out an endless scream, so piercing it smothered the noise of the engines, for a whole lap after the finishing line. Three versions of himself were screaming, perhaps four: racer and kid, kid and car, boy and kart, all with an echo of Tchê. ${ }^{9}$ A hysteric scream almost spilling his guts as he proclaimed his glory, etched it into the deepest of layers, behind the sky.

Then he stopped. Like a cetacean, a stranded sea titan. Exhausted. Motionless. It was a surreal atmosphere, one of bitter irony:

officials and doctors rushed to him, taking him from his cockpit as carefully as you transfer a plant, preserving the leaves and the roots. They removed his gloves only to discover that his hands were bruised, the muscles in his forearms tensed, almost spasming, unable to relax. "A knot at the back of the neck, right in the middle of the spine", the massage therapist noted: the tension of sixty laps plus six of pure agony culminated in physical suffering, the fiery burning of an erupting volcano.

"Relax Ayrton", a distant voice chanted repeatedly. The happy voice of a man who had hardly been noticed before. Ron Dennis stepped forward with the air of a towering man and the beady eyes of a bird of prey. He couldn't wait. Senna was now on his feet, but the two of them didn't touch. Any contact could hurt him, the wave of pain had just begun to ease. A fatherly embrace came to seize him where he was, in that same place twenty years before, gruff and familiar, as it was now, rust and rot showing beneath the surface.

A father's hug ignored the rule - "Do not touch" applied to anyone else - built a bridge between two men made of a "singular" matter, same blood and yet so distant, who never were and never could be closer than this.

\footnotetext{
${ }^{9}$ Lucio Pacual Ciascon was known by the nickname Tché in the Sao Paulo karting scene. He mentored many upcoming racers, refining their driving technique and broadening their knowledge of car engineering. [translator's note]
} 
Senna lifted the sad curtain of his gaze: sardonic, composed, dazed. A serene smile, he nodded to the organizers lined up. He went up the podium steps, arms by his side. He tried to lift the trophy with theatrical effort, giving up due to the pain and finally he raised his right arm as high as he could, a symbol of his will to win. Not a man inside the Interlagos track, none of the millions who cried in front of the television thought about taking advantage of the silence - the silence that suddenly engulfed Brazil - to go out and get their bread. To go out, break the shop windows and be the first to return, the best, with bags full of bread. No bread, now, beholding the manna of godlike Ayrton. It was time to be silent, now. Time to cry, to pray and to look to the sky. 


\section{Introduction:}

I was first introduced to Leonardo Guzzo's work in 2016 in an Italian language course. As I read L'atlante di Borges, I was immediately drawn into the world Guzzo had created and was compelled to read the entire collection Le radici del mare. The following year Leonardo Guzzo and I embarked on what would be the beginning of this translaboration project.

I chose a single story to translate - In fede, Ahab. Guzzo and I spent the best part of a year working on this one story which involved multiple versions, many revisions, and a lot of back and forth. It was a lengthy but successful process resulting in a translation that both author and translator were happy with. This translation was later published in The Journal of Italian Translation, which was a testament to the quality achieved through this approach. I think it is also noteworthy that almost four years later, as I began to revise the full collection of short stories, In fede, Ahab was one of the stories that required few changes. This very in-depth level of collaboration had created an effective translation and the beginning of what would eventually result in the collection of translated stories seen in this thesis.

My initial understanding of the translaboration process was very much surface level - Guzzo and I would work together on creating an accurate translation. Over the years, it became more nuanced. I began to contemplate what was the best way to work with the author, what was useful feedback which improved the translation and what would just hinder it; when to stop revising each story and decide it is finished; who has the final say and, notably, how important it is to build a relationship and trust between the author and the translator.

Intrigued by the process of translaboration, I wanted to test it out in a more extensive way, as this was something I hadn't found any examples of in the literature. While there were many examples of authors and translators collaborating and some even rather extensively, what I intended to do with Guzzo was more than a revision by the author and an ongoing list of queries - I wanted this to be a real back and forth, an ongoing open dialogue. This was a rare opportunity to take the author-translator collaboration beyond what is plausible to accomplish in a real-life scenario, creatively and critically.

For this endeavour to be successful, it was imperative to work with the right author. The nature of literary translation is creative, and I believe quite a personal exercise, so it was important that I worked with an author whose style of writing I identified with and a genre I was familiar with. Guzzo's stories had a magical and mythological quality to them - something I enjoy 
reading and writing. There were also numerous other factors that made Guzzo the ideal author for this project.

Firstly, the fact that Dr Marco Sonzogni could put me in contact with Leonardo Guzzo was very important. It may have been a lengthy process to get in contact with various contemporary Italian authors asking if they were interested in being involved in project of this nature. Secondly, I needed an author with a strong grasp of the English language as it was imperative that they were able to read my translations and provide significant input. Finally, I wanted an author whose work had not yet been translated into English. I was not looking to improve on an existing translation but rather to translate a text that otherwise wouldn't be available to an English, and in this case New Zealand, audience.

I initially intended to have the complete collection of stories in Le radici del mare but throughout the period I was completing the translations, I had the opportunity to translate various poems and two other stories by Guzzo (L'idolo and Beco) as part of my regular contributions to JIT - Journal of Italian Translation. These two stories brought a very different set of challenges, particularly when it came to the tone. I felt both these stories provided ample material to discuss in my commentary. These were also the two stories where Leonardo was most stubborn. They really put the translaboration process to the test as it required much back and forth to come to a version both Leonardo and I were happy with. I believe these needed to be in this thesis both to examine the different challenges in translating tone and to illuminate in greater detail the translaboration process.

Once I had completed translating all but one of the stories from Le radici del mare, plus these two extra short stories, I had reached the word limit for the creative component of my thesis so I chose to leave the final story out. It was also a question of time - La risalita is one of the longest stories and having found the back-and-forth process particularly time consuming with the longer ones, such as La mano del diavolo and Il vento, (these took the better part of six months to complete), I did not believe I would have enough time to get a final version of the translation to the same high standard I had achieved with the rest of the collection.

The order in which the stories appear in this thesis is another element which required deliberate consideration. Originally, I put them in chronological order of when I translated them. Putting them in this order seemed most appropriate, as I wanted to emphasise to the reader how my translations had changed and improved over time. After further thought however, I made the 
choice to change the order to match the Italian text as this is the order Leonardo intended for the collection.

When it came to the structure of this thesis, I placed the stories first and the commentary after as I wanted readers to be first immersed in the creative world of Guzzo, to fully appreciate the stories, the language, the voice of Guzzo. This is then followed by the more critical analysis and record of the translaboration process and then finally, the diary format commentary. I chose this style of commentary to reflect the specific challenges that arose as I translated the various short stories and also to highlight the ways in which I found my voice as not only a translator but as a creative writer. Francesca Cavagnoli points out the intrinsic link between translation and writing saying: "translation is a form of interpretation; but, I would add, it is also a form of writing". ${ }^{10}$ For me, the work was as much as an exercise in creative writing as it was an exercise in translation; when I leant into my role as a writer my translations improved.

One of my main aims was to create a cohesive and effective translation of Le radici del mare, a translation that could be enjoyed first and foremost as a piece of literature. I wanted to bring the beautiful stories in Le radici del mare to an audience that otherwise would not have been exposed to them.

\footnotetext{
${ }^{10}$ Francesca Cavagnoli, "Italian Authors Meet Australian Authors: The Responsibility of Writers as Translators,” The Translator 23, no. 1 (2017): 85.
} 


\section{THE TRANSLATOR'S DIARY}

\section{Introduction}

The following commentary has taken the shape of a translation diary - a process many professional literary translators like William Weaver ${ }^{11}$ and Richard Dixon have utilised. As such, it has the free-flow of a thinking-out-loud approach and a re-visitation of the problemsolving, choice-making process I have gone through, rather than an abstract and thus removed discussion of theoretical concepts and methodologies. For this reason, a division into thematic units based on actual translation challenges I have had to face, think about long and hard and finally resolve is, in my opinion, a more effective as well as a credible way to analyse the complex dynamics, internal as well as external, of the authors and works involved, that underscore the ever-evolving and so ever-unstable relationship between theory and practice. A number of books have proven particularly helpful in inspiring and shaping these notes. They include Translating Style by Tim Parks, for his analysis of the intricate complexities that make up an author's style, In Other Words by Mona Baker for the practical solutions to translation problems, Why Translation Matters by Edith Grossman for discussions about the field of literary translation and Pendulum Diary by William Weaver for its honest, open account of his various trials and tribulations translating Foucault's Pendulum: this was a particularly influential text because I could identify with the process and I appreciated the matter-of-fact tone. In the following sections these references will be present more or less overtly depending on the issues under discussion. I have therefore opted to keep my commentary as fluid as possible to invite the reader to understand the translation process as I have experienced it, in a direct manner.

This aspect of the thesis focuses on the analysis and commentary on this process. In parts one and two, I focus on Guzzo's writing and style and what my role as the translator entails. In section three I discuss the concept of translaboration and the pros and cons that come with working closely with the author. In section four I highlight the many and varied decisions that must be made by the translator and give an insight into how I arrived at the final translation.

\footnotetext{
${ }^{11}$ Isabelle Vanderschelden, "Authority in Literary Translation: Collaborating with the Author." Translation Review 56, no. 1 (1998): 26.
} 


\section{Leonardo Guzzo: His Work and His View of Literature}

Di prima ho ricordi confusi e incoerenti. Ricordi di un bambino in mezzo ad altri bambini. Ricordi di una spiaggia dove stavamo accucciati, come reti di pescatori buttate a inebriarsi di salsedine e di vento. Ricordi di nubi rosarancio che lambivano le isole dove noi dormivamo. E occhi che dall'acqua salivano a guardare il sole sciolto gocciolare sull'orizzonte. ${ }^{12}$

— In Fede, Ahab

Who is Leonardo and how did I come across him? (A short but comprehensive profile)

Leonardo Guzzo has quickly become a distinguished voice in the crowded Italian literary scene. In terms of the Italian canon, he can be placed within the tradition of journalist writers that includes some of Italy's most distinguished authors, such as the Nobel Laurate Eugenio Montale, Leonardo Sciascia, Dino Buzzati and Paolo Di Stefano. His Italian is modern but his approach to literature is better suited to the twentieth century rather than the twenty-first. It is still too early to assess his place and contribution to Italian literature, though without a doubt he is one of the most distinctive voices in Italian literary journalism, privileging the short-story as his ideal medium for both critical and creative writing. He published his first collection of short stories, Le radici del mare, in 2015, followed by his second collection Terre emerse in 2019. His writing is poetic and distinctive.

When I first began to translate Le radici del mare I immediately noticed the lyrical and often fabular or allegorical nature of many of the short stories, namely In fede, Ahab, La preda, and L'atlante di Borges. Guzzo's short stories, while simple in plot and sparse in character development, are thought provoking and full of beautifully striking images, metaphors and very specific vocabulary. These are the key stylistic elements of his writing which I strove to retain in translation.

Guzzo has a distinctive way of tackling plot. All stories in Le radici del mare have a simple plot or little plot at all. No plots could be termed as overly involved or complicated or as the main element of the story. Though his longer stories are more narrative based, the plot is still relatively simple, and his shorter stories tend to be more like poetic and philosophical prose.

\footnotetext{
${ }^{12}$ I have only confused and incoherent memories of before. Memories of a child amongst other children. Memories of a beach where we would huddle, like the discarded nets of fishermen, drunk on salt and wind. Memories of pink orange clouds which lapped at the shores of the islands where we slept. And eyes which rose up out of the sea to watch the molten sun as it dripped on the horizon - In Faith, Ahab [my translation].
} 
Guzzo's interest lies in the internal metamorphosis of his characters and this is usually reflected in the external plots and events as a symbol of what is occurring within. Guzzo's use of symbolism throughout his stories is a distinctive aspect of his writing. When I sent Guzzo a complete draft of my translations, explaining in detail the process of linguistic and cultural choices I had made, Guzzo replied and shared some insights about his own process of writing. Guzzo has said he wants both words and facts to be suggestive, evocative and inspire multiple layers of meaning, trying to tell the story of the inner evolution of a character, which is not necessarily progress but all the same dives deeper into his/her soul.

The real main character in all these tales is, in fact, l'Oceano, 'the Sea' (always capitalised). Guzzo has an almost 'ancestral connection with the sea' and this is a prominent element throughout his writing.

The people in his stories, on the other hand, can often be nameless or referred to simply as 'the man' or 'the old man', adding a universal quality to the characters and allowing the reader to focus instead on the ideas that Guzzo is trying to highlight. It is notable that there are very few female characters - and if there are any, they are often just referred to a few times throughout the story. The only story where this differs is Il Vento Se Ne Infischia, where Jane is one of the main characters. This choice was an intentional one for Guzzo. He has also discussed how, as Le Radici del Mare was his first collection of short stories, written throughout his twenties, the male perspective was more instinctive, and he did not feel as confident in writing from the female point of view. However, while female characters are not prominent, male characters are not particularly developed either because, as noted earlier, character is not what drives Guzzo's stories. This absence of the female perspective is something that has begun to change in his second collection of short stories Terre emerse.

Perhaps one of Guzzo's most notable stylistic elements in Le radici del mare is his very detailed and specific word choices. The precise boat and sea terminology was something that was imperative to replicate in the English translation and required a lot of research on my part as I was not familiar with the vocabulary in Italian or English. Guzzo has chosen each word for a specific reason and, when reading his work in Italian, there is the strong sense that no word is there by chance. In translating his works, it was crucial that I took the same care in choosing each word.

There are also certain words and phrases that recur throughout this collection of short stories, all so notably 'Guzzo', and which bring the focus to particular concepts and ideas and tie the collection of short stories together. Examples of these words are:

- bagliore 
- tirando a galla

- orlare

- segno

- varco (a favourite term used by the Italian poet and Nobel Laureate, Eugenio Montale. is an author that inspires Guzzo).

- abisso

- confine

- l'Oceano (this is always capitalized)

- le linee della marea (the concept of liminal spaces; thresholds; margins/periphery is something is present in many of the stories).

- segno

It was important then to find the specific word in English and also to use it as consistently and/or repetitively as the author had originally done. Some compromises did have to be made however, as some of these words have varied and complex meanings that cannot always be replicated in English with one word. Nevertheless, the intention was to replicate this stylistic aspect as closely as possible.

In Le Radici del Mare the emphasis was on honing my knowledge on specific sea terminology. However, when Guzzo's writing is not focused on the Ocean, it is focused on his other passion - Sport. In the same way that I had to learn the specific 'sea' terminology, there was a new learning curve here - especially with Formula One. I didn't know any of these terms in English. These are both areas that Guzzo is passionate about and therefore he uses specific jargon that the translator needs to acquire quickly.

Guzzo's expresses his views on life through the concept of sport. He envisions sport as a challenge, a modern-day battle, an arena where athletes push themselves to their limit, striving for success within the constraints of the game. On the sports field, there is no room to lie and the athlete is forced to see how far he is willing to push his limits. It is an environment in which passion often prevails, where talent and hard work pay off but where fate also plays an important role, like in all great trials of spirit. Guzzo's short stories which focus on sport differ in many ways from his tales of the sea. While these stories are still very much characteristically in Guzzo's signature style, there is a stark difference in the tone and pace. There is a sense of urgency and immediacy that is far more present in the sport stories.

Sport is presented with the religious fervour and connotations typical of the Italian and South American contexts. In the two sport themed stories, L'idolo and Beco, there is an idea that the stadium is a place of worship and both Senna and Maradona are described as if they 
are almost god-like. The focus of Sport draws out Guzzo's cultural influences and background and the importance of sport in the Italian context. This is not a significant part of his Sea stories which are more universal in setting, character and theme.

What elements in his writing appealed to me in terms of my own taste for reading and writing literature and persuaded me to translate his short stories?

Guzzo and I have similar literary inspirations and Guzzo's style reflects our literary and linguistic preferences, notably authors such as Hemingway, Melville, Borges and Neruda. One of the elements that struck me was the simplicity of the stories and, most notably, the very precise way in which Guzzo selected each and every word. This made it much easier for me to access both his mindset and his allusions.

So, what translation approach would serve Guzzo's stories and style? What parts of his writing require a scholarly work and how much space would creativity and original writing play? How does one distinguish between those two modes? It was these sorts of questions I had to ask myself before embarking on this project. While I did not have all the answers when I began, throughout the translation process I would find out. 


\section{Translation as Creative Writing - What's in it for my Writing?}

What exactly do we literary translators do to justify the notion that the term "writer" actually applies to us? For the most fundamental description of what translators do is that we write - or perhaps rewrite - hoping that readers - will perceive the text, emotionally and artistically, in a manner that parallels and corresponds to the aesthetic experience of its first readers. This is the translator's grand ambition. Good translations approach that purpose. Bad translations never leave the starting line.

— Edith Grossman (Why Translation Matters).

In this section I explore the intersection between the scholarly and the creative components to literary translation, trying to shed light on the pros and cons of each approach and above all how they can combine to produce a translated text that is at once a translation and a literary work in the target language. Above all, I privilege the encounter with the text, the skopos of the text, and the enjoyment of the reader to any abstract theorization of the translation process. I am, however, conscious that an awareness of translation theory can extend as well as embolden the range of possibilities I consider when I translate. Certain theoretical concepts have been highly beneficial to my translation process, in particular those that deal with translation problems with realistic examples. Insights offered by translation theories such as those by Tim Parks and Mona Baker aid the translator in discovering different methods to approach specific elements of their work. These studies have been a useful starting point as every translation requires different approaches for different occasions. As Jean Boase-Beier says, "[k]nowledge of theories and approaches should be part of the translators toolkit" and that "knowledge of possible and actual theories and views, of language, literature, translation or style, is as helpful to the translator as any other knowledge about the world in which he or she lives and operates". ${ }^{13}$ But as Boases-Bier goes on to discuss, other information can also be helpful. In this case gaining a greater knowledge on specific terminology surrounding the sea and marine life was imperative to create an accurate translation. It also has to be said that the skills learnt through the practical process of translating are invaluable. They are 'the translator's grand ambition,' and this is something that I believe cannot be solely found in theory.

Literary translation requires the translator to be creative and not only in the problemsolving way that this term is often associated with in the field of translation studies. While problem solving is an important skill a translator will use time and time again, it is also necessary for the translator to have a creative flair for writing. Kamal Osman Sharfi Mohamed

\footnotetext{
${ }^{13}$ Jean Boase-Beier, Stylistic Approaches to Translation (New York, St. Jerome Publishing, 2006), 6.
} 
also highlights this: "While the notion of creativity in translation has been considered with some suspicion, creativity is an inevitable aspect of the translation process. Creativity is an important task, which at an individual level involves problem solving and on a societal level leads to innovation". ${ }^{14}$

I believe that this is a very creative task and should be treated as such. As a literary translator my aim was first and foremost to create or perhaps recreate a story for the target audience as if they were reading it in the original language. Ulla Roseen discusses the creative process that translator goes through, describing how:

Translation is an act of love, but at the same time the translator has to be a good reader, a close reader. In total solidarity with the work, she has to use all her imaginative resources to recreate the world of the poem or the novel she is translating. I know from experience that this imaginative power, is the total identification with the work translated, creates new worlds inside me, worlds that become part of my dreams, worlds that integrate with my own fund of experience. ${ }^{15}$

A large component of this task was finding my voice as a literary translator. I had to discover what my writing style for Guzzo would look like. In the same way that I focused on what stylistic elements encompassed his writing, I had to focus on creating and honing the stylistic elements of the translation.

Why short stories?

When I initially began looking into taking on a project of this magnitude, I also considered the possibility of translating a novel. Guzzo has written a few novels, which are still unpublished at this time though I would have had access to them if I had wished to translate a novel. I also contemplated the possibility of working with various authors, with the view that it could provide me with a variety of themes and stylistic elements to translate and, in turn, it would make for an interesting component to my theoretical commentary. However, this would not work as well for the translaboration aspect, as building a relationship with an author takes time. It also takes time for the translator to become accustomed to the stylistic traits of one author, let alone many, and it has been always imperative to create a high-quality translation.

Ultimately, I opted for a collection of short stories as I consider the standard length of a short story as an ideal 'testing ground 'for both literary translation and original writing. Each short story highlights different aspects and different challenges of translation which in turn would aid the theoretical component of this thesis. It was for practical reasons too. Working

\footnotetext{
${ }^{14}$ Kamal Osman Sharfi Mohamed, "Literary Translation as a Means of Creativity," Global Journal of Arts, Humanities and Social Sciences 4, no.1 (2016): 49.

${ }^{15}$ Roseen, Ulla, "Listening to the Voice of the Author," in Translation of poetry and poetic prose, ed. Sture Allèn (World Scientific Publishing Co Pte Ltd, 1999): 250.
} 
with Guzzo in a manner as highly collaborative as translaboration also lent itself nicely to the short story format, allowing us to work extensively on one story at a time to ensure a highquality end product.

I was looking for a work of literature that didn't rely heavily on the reader having specific knowledge of Italian culture, or components which could render parts of the story incomprehensible for the target audience. This was an element that drew me to Guzzo's work as it is not inherently set in Italian culture. Although some of his stories are set in Italy, many are not, making his stories generally more universal. This does not mean he sits outside the Italian canon, but it means that regional as well as national and international models and influences are combined to create a universal narrative. This is also true for many of the literary allusions he uses. They are well-known global literary classics - authors as different as Melville, Borges, and Hemingway to name the most obvious presences in his work.

If, in a writer's work, there are echoes - more or less evident; more or less influential - of other writers and other works, the translator needs to address this. In the translated text, the translator - that is to say, the author in the target language -should attempt to convey this as closely as they can, sometimes metaphorically sometimes literally. However, we must also ask ourselves: what are the implications of this closeness? What makes it successful? Whose words are we reading in the end?

\subsection{Realia: Culture Specific Language}

As I have mentioned above, this collection of short stories does not heavily rely on the audience being familiar with Italian culture. That being said, it does not mean it is void of tokens that the reader may be unfamiliar with. When it came to tackling the elements of realia present in Guzzo's stories, it was imperative they remained in the translation, but since I did not want it to become unclear to the reader, I needed to find a solution for each situation. I wanted to ensure that these elements were preserved and that it was clear these stories were not written in the UK, or the United States but were based in a different culture.

Clifford Landers quotes "Murat Nemet Nejat has put it this way: A successful translation must sound somewhat alien, strange, not because it is awkward or unaware of the resources of the second language, but because it expresses something new in it." ${ }^{16}$ This is what I wished to

\footnotetext{
${ }^{16}$ Quoted in Landers, Clifford E. Literary Translation: A Practical Guide. (Clevedon, UK; Buffalo: Multilingual Matters, 2001): 52.
} 
achieve with Guzzo's work. I wanted it to sound new and interesting, as it is in the original, but I still wanted it to be legible and fluent.

I thought long and hard about how I wished to tackle the following examples. In many cases, I opted to use footnotes, as this was a method that allowed the 'foreign' word or element to remain in the text but also provided the reader with an explanation.

The first example I wish to discuss appears in Un altro mare. Much of this story focuses on the old man's journey in South America and therefore has certain words in Spanish, one of these being Rio della Plata. When translating this term, I knew I didn't want to translate the name in English making it something like 'river of silver' or 'river of money' as this would be confusing and not in keeping with the way I had chosen to translate such things in other stories. Ultimately, I decided to translate it as Rio della Plata river, keeping the name in Spanish as Guzzo had done in the original Italian, but with the addition of the word river because I wasn't convinced that the majority of English readers would know that rio was the Spanish word for river and, while this would essentially be repeating the word river, I preferred how this sounded over River della Plata - this seemed to be the best compromise. When Rio della Plata was repeated in the following sentences and paragraphs I no longer added river - keeping it simply as Rio della Plata, it had now been established to the reader that this was a river and therefore no longer necessary.

The second example is trabucco, used in La preda, I will discuss this term in greater detail later on but in terms of dealing with it as an element of realia, in this instance the only option I considered was keeping the Italian term and adding a footnote. Trabucco has no English translation and translating it simply as a fishing contraption or tool would strip away not only the Italian element but also a specific sea term - one of Guzzo's key stylistic choices that needed to remain. The use of a footnote in this instance allowed me to keep this element while also explaining what it means to the reader.

In Un tono d'azzurro, I decided to keep the movie title Pane amore e fantasia in Italian and opted to use a footnote for clarification in this instance too. I chose to keep it in the Italian to have a more precise reference to Vittorio de Sica, since De Sica is also not coincidentally the nickname of the main character in this story, while also to colour the English translation with elements of Italian culture in a way that is still accessible to the target audience.

The next example comes from L'atlante di Borges, another story set in South America. Similarly to the previous example, I chose to keep Doña in the Spanish spelling. Doña or Don are commonly understood as titles in English and again this is replicated in the original Italian. 
In other instances, throughout the collection, I have kept this choice consistent, such as in $L a$ mano del diavolo, where the character is also called Don Miguel in my translation. Using the English equivalent 'Mr Miguel' or 'Mrs Angela' would have sounded odd and out of place in the context.

The final examples of realia I would like to discuss appear in Finis terrae. Originally, I had translated the title of the story as "The End of the Earth', later deciding to keep it in Latin as Guzzo had chosen. This was more in keeping with the way I had dealt with other similar examples throughout the collection. For the most part, where appropriate, I left non-Italian words in the original language, as this had been a deliberate choice for Guzzo and therefore was something I wanted to replicate in my versions. Leaving this title in Latin also retains the allusion to the French district this story is set in: Finistère. Similarly, I opted to leave the poem at the start of this story in French, as this story is set on the French island of Ouessant.

As I revised the collection of short stories, I reflected on how I wanted to translate these elements of realia - how much did I want to spell out for the reader, how much could they be expected to glean themselves? Cavagnoli perfectly describes this:

Should the reader be left in charge of covering the chronotopic distance between the culture of the prototext and the culture of the metatext or not? (6) Personally, I always choose a translation that - within possible limits - is adequate to the prototext. When I translate, I find maintaining as many of the prototext's elements as I can to be of utmost importance. This allows me to preserve it as wholesomely as possible as the expression of a different culture, I believe that learning new aspects of another culture is an extremely enriching experience for the reader. ${ }^{17}$

I, too, believe that learning about another culture is rewarding for the reader, and one of the reasons to read more translated literature. Ultimately, I aimed to leave as many of the 'foreign' elements in the stories as possible in a way that would still be accessible and understandable.

\footnotetext{
${ }^{17}$ Francesca Cavagnoli, "Vola Gigino?: Translating David Malouf’s Novels into Italian,” Southerly 63, no. 1 (2003): 74.
} 


\section{Translation and/as Collaboration: Two Writers at Work}

Nonetheless, learning to write together was not always easy. We had to learn to give and take, to listen more carefully than we were wont to do, to negotiate differences in style and substances, to wait patiently for the other to speak or to write, to be critical and supportive at the same time, to be responsible to one another, and to laugh rather than cry at frustrations and setbacks. And so much more.

- Andrea A. Lunsford and Lisa S. Ede (Writing Together).

Collaboration between author and translator is not uncommon in the field of literary translation, though the degree of this relationship varies, some authors preferring to have limited involvement for a variety of reasons - including their lack of knowledge of the target language or their belief that "once a book is translated into another language, it becomes another book, and thus each version becomes a parallel but self-standing text". ${ }^{18}$

Often authors will provide clarification on specific problems or references when needed. At times, this relationship develops further and leads to a more extensive collaboration such as the now legendary co-operation between Umberto Eco and William Weaver, ${ }^{19}$ Jorge Luis Borges and Norman Thomas di Giovanni ${ }^{20}$ and Suzanne Jill Levine and Guillermo Cabrera Infante. ${ }^{21}$

Translaboration takes this a step further. This is where the author and translator collaborate comprehensively throughout the entire translation process (Borges and di Giovanni collaborated extensively and may have been close to the translaboration process) ${ }^{22}-$ from the initial drafts to the final text. This mode of collaboration examines the topic of co-ownership and the role of the voice of the translator. For this to be successful it is imperative to build a relationship with the author, one that is built on mutual respect.

The ongoing discussions, the open line of communication with Guzzo and the overall collaborative nature of this project and the more important changes to the translations have come about from these discussions.

With the input of the author, the translator can be sure that what he or she is translating is, in fact, what was originally intended. I found this aspect reassuring. Having the peace of

\footnotetext{
${ }^{18}$ Isabelle Vanderschelden, "Authority in Literary Translation: Collaborating with the Author," Translation Review 56, no. 1 (1998): 22.

${ }^{19}$ William Weaver, "Pendulum Diary," Southwest Review 75, no.2 (1990): 150-178.

${ }^{20}$ Borges, Jorge Luis. Selected Poems, trans. Norman Thomas di Giovanni (Harmondsworth: Penguin, 1985): forward.

${ }^{21}$ Suzanne J Levine, "Writing as Translation: Three Trapped Tigers and a Cobra," MLN 90, no. 2 (1975): 265277.

${ }^{22}$ The fact that I am not only a collaborator but also the writer has given us greater freedom, since we are less tied to verbal precision than to inner meanings and intentions.

Borges, Jorge Luis. Selected Poems, trans. Norman Thomas di Giovanni (Harmondsworth: Penguin, 1985): xiiiix.
} 
mind that I had discussed the meaning of a certain (usually more challenging) passage with Guzzo, gave me greater liberty to steer away from the exact words and focus on conveying the meaning of the passage in a more liberal manner.

And like any relationship this exchange is not only or entirely positive or negative.

It can be a lengthy process, as the back and forth can become time consuming. There have been times when Guzzo and I have gone back and forth on certain sections, seven or eight times even, as we could not come to a mutually satisfactory decision.

In the translaboration process, as the author is involved throughout the entirety of the translation process from the first draft, this requires many versions of each translated story. Guzzo was given my initial draft as I finished translating each short story and from this point on provided his suggestions and opinions. It takes a certain amount of vulnerability to let the author have access to the earliest drafts before they have been polished and to have these criticized. Especially as a novice translator, it was quite daunting supplying the author with initial drafts that were far from perfect. As time went on, Guzzo and I built a stronger relationship, and I became more familiar with his style of writing. In turn, my drafts improved, and this element became easier. Nevertheless, there is still an element of creative vulnerability, in letting someone else in on your first efforts. In some ways, this raw stage of the work remains the purest of efforts, regardless of accuracy and fluency, allowing Guzzo to get a grasp of the style and what the translation will eventually become. No doubt there is an element of this for the author too. Surrendering a level of ownership of their work to the translator can be difficult, as can be seen with authors such as Milan Kundera ${ }^{23}$ or Antonio Tabucchi, ${ }^{24}$ who both notably would only release the rights to the translation of their works in a language they were very familiar with, so they could be sure every word was as they desired. It is important for me to note that working with Guzzo was a far cry from this. Though Guzzo is protective of his work (understandably so), he was respectful of my job as a translator and trusted me to do this task. It would be nearly impossible to embark on this type of project without there being a mutual respect and understanding between both author and translator.

\footnotetext{
${ }^{23}$ Milan Kundera, Testaments Betrayed, trans. Linda Asher (London: Faber, 1995).

${ }^{24}$ Tabucchi: "I intervened in the work of my translator to explain some specific words or regional idiomatic phrases. I know how hard it is to translate this book. This is why the French translation will be the only one that I will authorize". Isabelle Vanderschelden, "Authority in Literary Translation: Collaborating with the Author," Translation Review 56, no. 1 (1998): 22-31.
} 
The question of where the final authority lies is an interesting point when it comes to literary translation. While credit is assigned to the translator, it is not necessarily acknowledged by the general public. Any given person may say they have read a book by the author, without even considering that the book has been translated.

Isabelle Vanerschelden discusses the concept of authority in translation stating that "collaboration between author and translator involves an element of subordination on the part of the translator, due to a common assumption that the author knows best, associated with a natural feeling of reverence toward the person of the author". ${ }^{25}$ At times Guzzo has provided extensive feedback where there is more red on the page than not. This can be quite daunting and not necessarily an accurate representation of what needs to be amended, nonetheless the first impression on the translator can be quite demoralizing.

Here is an example from Finis Terrae illustrating the level of intervention:

And so, he left the beaten track and dared to follow the path of light, forever renouncing to the quiet of the sea, the damp recollection that made it perpetually equal to itself, a non-place with no dock nor any mark, dipped and swinging in the eternal present. The Giant wandered a lot, in and out of his imagination, and then one day, finally, he found a gap in that vast prison: with one last effort, a grand unimaginable move, he broke the boundaries of time, came out to the sun and knew. himself under the sun, he looked about. He immediately called the females to come and look and He took the calves on His back to hoist them over the water. All together they discovered empty dried spaces, with lush scenery, flooded with golden rivers of gold and another sea, azure and rarified, above their head. From then on, that sight remained trapped in their dreams. Every day of their lives they worked to attain that. On the back of the Grey Giant and then on its own, the pod rose to the surface; following the underwater ridges, in the bed of high gradient streams, they reached the land above. They dreamed of leaving the sea, growing legs and wings to live on earth and in the air: hanging by the thread of a dream, they became smaller and lighter, they learned to balance on the ground and leap into the sky, darting and twirling, lords of the infinite space. No more certainty they found in that immeasurable vastness than in the quiet comfort of the deep. Faced with a universe that stretched out endlessly, they felt a compelling desire for essence, a burning thirst to get back to the start. Then the marine nation split up: some went on locked in their new form, faithful to their long-cherished dream of freedom; others went back home, down in the sea, to the place they were naturally assigned by fate.

It is also interesting to note that this was the final short story I translated and the one I was most confident that I had found the balance between being faithful and accurate and creating a story that worked effectively in English. To then receive this amount of feedback was disheartening. In these situations, it is important to remove ego and look at it in an objective manner.

The idea that the author knows best is something I most certainly identified with when I began working with Guzzo. I believed that, as the author, he must know best, and the final

\footnotetext{
${ }^{25}$ Isabelle Vanderschelden, "Authority in Literary Translation: Collaborating with the Author," Translation Review 56, no. 1 (1998): 25.
} 
word lay with him. Serenella Zanotti explains the conflict between author and translator authorship in the following terms:

Claims for originality and authority have been variously made in reference to translation in Western theories. In particular, the post-structuralist questioning of the very notions of originality, creativity and authorship led to a breakdown of the traditional author/translator dichotomy. ${ }^{26}$

Over time I began to change my view on where the final word lay. While I still believe to some degree that the author does know best, I began to see that there were certain instances where it was not a question of meaning or style but more simply a question of the correct and most appropriate use of the English language. This was the area where, as the native speaker, I knew best.

I began to view him as the author of the original text, but myself as the author of the translation and while I always strove to come to a resolution that both of us were content with in the end, for this process I wanted to have the authority over the translation.

At times, Guzzo had many suggestions on a specific passage which did not make a great deal of difference on the final translation once all queries had been addressed. It could become a very time-consuming task to go through his often-extensive feedback, especially with the longer stories that could be over 14,000 words and where almost all sentences required close re-examination. This happened on a few occasions. Particularly in the later stories I translated, I was often choosing to opt for a freer translation, focusing on the flow of the English text rather than strictly adhering to the Italian original and Guzzo had many opinions on this. When this process began, I opted to adhere closely to the Italian text in fear of my translation doing an injustice to the original. Over time, I began to value my own writing as a translator and leaned into the more creative aspect of translation, following my instincts and focusing on a text that worked successfully in English.

Depending on the author's knowledge of English, this can also bring about some very interesting suggestions, at times amusing; at times negotiable; at times untenable. Guzzo has a strong command of English and often shows his knowledge of English with very nuanced questions regarding grammar and vocabulary but also, at times, he does not have an idiomatic command of English and sometimes is not aware of all the connotations of certain

\footnotetext{
${ }^{26}$ Serenella Zanotti, "The Translator and the Author: Two of a kind," in The Translator as Author Perspectives on Literary Translation, ed. By Claudia Buffagni, Beatrice Garzelli and Serenella Zanotti (London: Transaction Publishers, 2011): 79.
} 
words/idioms. Tim Parks highlights this perfectly when he states, "that much of language has to do, not with the grammatical rules and transformations ... (though they are vital), but with what the people who speak the language consider normal and acceptable". ${ }^{27}$ These next examples come from L'idolo; this story posed many issues. Due to the nature of the topic, the tone differed greatly from the short stories in Le radici del mare and required a more colloquial and immediate tone that better suited the sport theme.

Here is the first example in Italian:

Sembra il parto di una fantasia eccitata,

And here is my initial translation in English. While 'fantastical dream' differs from the exact words in the Italian, I believe they much better conveys the intent of the original story:

It seems like the start of a fantastical dream.

It seems like the start of an excited fantasy.

Guzzo was initially not content with the deviation from the Italian and offered a more literal translation. In this instance, I discussed with him that 'excited fantasy' could have other connotations and perhaps was not best suited to describing a group of football players. Mona Baker uses the term collocational restrictions: "These are semantically arbitrary restrictions which do not follow logically from the propositional meaning of a word." ${ }^{28}$ In this instance Guzzo was accommodating and agreed that my first translation would be acceptable.

Here is another example from L'idolo, first in the original Italian:

Vetture di presidenti ruspanti, allenatori declassati, calciatori fermi a metà sogno, stipendi da impiegati e boati di Azteca a gonfiare le tempie.

This example posed an issue as it was an image which worked beautifully in Italian, but I did not think it had the same effect in English. For this reason, I decided to go with an option that was a little more liberal but, I hoped, clearer:

The cars of cocky club presidents, downgraded coaches, players who had to put their dreams on hold, blue collar workers and a piercing clamour of the Azteca stadium in their head.

The cars of cocky club presidents, downgraded coaches, players who were stuck in the middle of their dreams, blue collar workers and a piercing clamour of the Azteca stadium in their head.

\footnotetext{
${ }^{27}$ Tim Parks, Translating Style, A Literary Approach to Translation, A Translation Approach to Literature Second Edition (New York: Routledge, 2014), 3.

${ }^{28}$ Mona Baker, In Other Words: a Coursebook on Translation Third Edition, (London: Routledge, 2018), 14.
} 
Guzzo again wished that I remain closer to the original image, so we discussed it, and in the end, he agreed we could keep my original translation. Firstly because, "players who were stuck in the middle of their dreams", was considerably longer than its Italian counterpart, a common issue. Secondly, having discussed with Guzzo the meaning of this sentence, my original English version adhered closer to his intention.

This was the story that dealt with the most cultural-specific concepts and this was an element I paid careful attention to. In the same way I initially had difficulty translating some of the football-specific terms - that are far more commonplace in Italy, where football is almost a religion - I still wanted it to be clear for target language readers that may not have the same knowledge of the sport. In the Italian text Guzzo refers to the Azteca Stadium in Mexico simply as Azteca. I chose to translate this as Azteca Stadium, making it explicit to readers that Guzzo was alluding to when Argentina won the 1986 world cup (with Maradona) in Mexico.

The final example is again from $L$ 'idolo. Here is the original Italian:

Con gli occhi chiedono ai bambini di trovargli un senso.

This sentence highlights the minor differences in languages that at times cannot be changed.

They look to the children to try to make sense of it all.

They look to the children to ask sense of it all.

When reviewing this sentence Guzzo wanted to know why it was not possible to simply translate it as "ask sense", as he believed that the addition of "try to make" was making it longer and compromising the simplicity of the sentence. This was an example where I did not have much choice as "make sense" is just more grammatically correct.

There have also been instances where I have had to change it back to what I had written initially, disregarding Guzzo's suggestions altogether. This may happen when he wanted the English to match the Italian grammar and syntax but perhaps it may not be the most favourable translation. These changes can be particularly frustrating.

The following example is from La mano del diavolo:

Lo spettro di quell'altra donna lo sfiorò e svanì nel nulla

which I had originally translated as:

the ghost of that woman brushed against me before vanishing 
Guzzo wanted to change 'brushed' to 'touched lightly'. This is not a case where I had misunderstood as what he was suggesting was a synonym. In this case I felt that 'brushed' worked better in the context.

Another example from the same text, first in Italian, followed by my translation;

"Non protestò, e non per indifferenza o eroismo o sete di martirio"

"he did not protest; it was not out of indifference but"

Guzzo wished to change this to "for indifference" but this is just not idiomatic in English. As Mona Baker notes "words which we might think of as synonyms or near synonyms will often have quite different sets of collocates. English speakers typically break rules, but they do not break regulations." 29 At times it was difficult to convince Guzzo of this.

He pretended it had never happened, even though everyone in the village knew, and when she died of cancer, a lifetime ago, he had cried and never thought, even for a moment, that it was her rightful punishment.

Originally, I had a lifetime ago but Guzzo wanted a lifetime before. While 'before' is technically correct, 'ago' is what a native language speaker would say.

There have been instances where Guzzo was particularly insistent, putting forth suggestions which relate more closely to the Italian but don't necessarily work very well in English. I can understand his conviction as he feels the English translation does not best reflect the original sentence but ultimately, as the native speaker I know what will be clearest to the target reader. (It is the difference between having a surface and a deep and nuanced knowledge of the language).

This was most prevalent when translating Beco, another sport themed story, which posed many of the same issues that came up when translating I'idolo. Imitating Guzzo's careful use of tone and metaphor to produce a story that encapsulated Guzzo's ideas about sport proved particularly difficult. This short story required the most back and forth of all our translaborations, taking seven or eight different versions to find something both Guzzo and I were happy with.

The first paragraph was very problematic. Here it is in the original Italian:

\footnotetext{
${ }^{29}$ Mona Baker, In Other Words: a Coursebook on Translation Third Edition, (London: Routledge, 2018$), 54$.
} 
Gli uomini in tuta arancione capriolavano. Dalle murate degli spalti salì un urlo altissimo, un tuono a scuotere la terra.

Le tribune, come le catapecchie affastellate sulle colline di Sao Paulo, sembravano tante bolge infernali. Un muro quasi verticale, gremito di formiche che urgevano sulle ringhiere, il rimescolio di un'immagine che sembrava compatta, il turbinio interno di una nuvola. Uomini cenciosi si abbracciavano, salivano a cavalcioni l'uno sull'altro, formavano figurazioni acrobatiche - piramidi, grappoli, ogni acino del valore di dieci real. Ogni uomo in quel quadro valeva il prezzo del biglietto. Altro non c'era nella sua umanità. Il biglietto e quella gioia sconcia, sterile, gioia per la gioia, che divorava se stessa coi morsi della fame.

With my initial translation my main aim was to clarify meaning and understand what was Guzzo's primary intent for this passage and, because of this, I stuck to a rather literal translation, with intent to make further changes when the meaning was clarified.

The men in orange jumpsuits were doing somersaults. The loudest of screams rose from the bleachers, a noise that shook the earth.

The grandstands, packed like the shacks on the hills of Sao Paulo, looked like many circles of hell. A nearly vertical wall of people, a hive of ants heaving against the railings, a single image in turmoil yet compact, the whirlwind inside a cloud. Tattered men threw their arms around each other clambering on top of one another into acrobatic formations - human grape-like pyramids, where each person is worth ten Brazilian reals. Every man in that picture was worth the price of the ticket. Their humanity consisted of nothing else. The ticket and that obscene, sterile, joy for joy's sake that devours itself with great ravenous bites.

Guzzo's suggestions and feedback allowed me to get a better grasp of the story.

The men in orange jumpsuits were doing somersaults. The loudest of screams rose from bleachers, a noise that shook the earth.

The grandstands, like those packed shacks on the hills of Sao Paulo, turned to some hellish bedlam. A nearly vertical wall of people loads of ants heaving against the railings, the stir of an image that still looked compact, the whirl inside a cloud. Shabby men embraced, then straddled each other into acrobatic formations - pyramids or grapes, with each grape worth ten Brazilian reals. Every man in that picture was worth the price of the ticket. Nothing else in their humanity. The ticket and that obscene, sterile joy for joy's sake, that devoured itself with ravenous bites.

My second translation incorporated Guzzo's feedback and worked towards a more cohesive text, but there were still some sections that remained problematic - particularly the metaphor of the grapes this metaphor was very difficult to come up with a version that would work as well in English as it did in the Italian. What is a beautiful rather clear image in Italian, became wordy, convoluted and confusing in my English translation.

The men in orange jumpsuits were doing somersaults. The loudest of screams rose from bleachers, a noise that could shake the earth.

In both the grandstands and the shacks packed like the favelas on the hills of Sao Paulo it looked like a vision from hell. A nearly vertical wall of people, a hive of ants heaving against the railings, a single image in turmoil yet compact, the whirlwind interior of a tempestuous cloud. Tattered men threw their arms around each other clambering on top of one another into acrobatic formations - human pyramids, where each person is worth ten Brazilian reals. Every 
man in the picture was worth the price of the ticket. Their humanity consisted of nothing else. The ticket and that obscene, sterile, joy for joy's sake, that devours itself with great ravenous bites.

I continued to refine and clarify this first paragraph with my third translation and for the most part I was pleased with what I had achieved. I was still unconvinced on the translation of the metaphor.

The men in orange jumpsuits were doing somersaults. The loudest of screams rose from bleachers, a thunderous noise that shook the earth.

The grandstands, like the packed shacks on the hills of Sao Paulo, looked like a hellish bedlam. A nearly vertical wall of people, a hive of ants heaving against the railings, a trembling image that seemed compact, a whirlwind inside a cloud. Tattered men embraced, clambering on top of one another into acrobatic formations - human (grape-like) pyramids, where each person is worth ten Brazilian reals. Every man in that picture was worth the price of the ticket. His humanity consisted of nothing else. The ticket and that obscene, sterile joy for joy's sake that devoured itself with ravenous bites.

I sent it back to Guzzo for his approval and usually this is where the cycle of feedback would end. But with this story neither of us could agree on what would be the best translation for this section. This was followed by many emails back in forth discussing the best approach and many options.

The men in orange jumpsuits were doing somersaults. The loudest of screams rose from bleachers, a thunderous noise that shook the earth.

The grandstands, like the packed shacks on the hills of Sao Paulo, looked like a hellish bedlam. A nearly vertical wall of people, a hive of ants heaving against the railings, a trembling image that seemed compact, a whirlwind inside a cloud. Tattered men embraced, clambering on top of one another into acrobatic formations - human pyramids, or grapes, each person a grape worth ten Brazilian reals. Every man in that picture was worth the price of the ticket. His humanity consisted of nothing else. The ticket and that obscene, sterile joy for joy's sake that devoured itself with ravenous bites.

Here is one of Guzzo's suggestions:

The men in orange jumpsuits were doing somersaults. The loudest of screams rose from bleachers, a thunderous noise that shook the earth.

The grandstands, like the packed shacks on the hills of Sao Paulo, looked like a hellish bedlam. A nearly vertical wall of people, a hive of ants heaving against the railings, a trembling image that seemed compact, a whirlwind inside a cloud. Tattered men embraced, clambering on top of one another into acrobatic formations - clambering on the top of each other into acrobatic grape-like formations - human pyramids where each person, a grape worth ten Brazilian reals. Every man in that picture was worth the price of the ticket. His humanity consisted of nothing else. The ticket and that obscene, sterile joy for joy's sake that devoured itself with ravenous bites.

And another... 
The men in orange jumpsuits were doing somersaults. The loudest of screams rose from bleachers, a thunderous noise that shook the earth.

The grandstands, like the packed shacks on the hills of Sao Paulo, looked like a hellish bedlam. A nearly vertical wall of people, a hive of ants heaving against the railings, a trembling image that seemed compact, a whirlwind inside a cloud. Tattered men embraced, clambering on top of each other into human pyramids - acrobatic grape-like formations, where each person was a grape worth ten Brazilian reals. Every man in that picture was worth the price of the ticket. His humanity consisted of nothing else. The ticket and that obscene, sterile joy for joy's sake that devoured itself with ravenous bites.

This is the final version I came up with and both Guzzo and I agreed that this was a solution we could agree on. In this instance, I still think this could be improved on, but I am at a loss as to what that would be. In every translation there is a time when the translator must step back and decide it is finished. This can be difficult as there are always further changes and improvements that can be made but then where would it end? In these instances, it can also be beneficial to take a step back from translation and revisit it with a fresh pair of eyes, weeks or months later.

This is a further example from Beco; here is the original Italian:

"Ayrton ha perso le marce", era corso di posto in posto lungo tutta la pista.

My first translation was very literal. I was unfamiliar with Formular One terminology in Italian and English, initially forcing me to stay close to the original. After years of working on Guzzo's stories that focused on the sea, I had become accustomed to that terminology in English and Italian. I had to start this process again, learning how to incorporate this new vocabulary into the translations effectively.

"Ayrton's lost the gear box", he jumped from position to position along the track.

Guzzo's feedback clarified some elements and not others...

"Ayrton broke his gears" ran from post to post along the track.

In my second translation I took on Guzzo's feedback, while also making it more idiomatic.

“Ayrton's gear box broke" spread from post to post along the track.

Guzzo had further suggestions.

"Ayrton broke his gear box" ran from post to post along the track.

In my third translation I did not take Guzzo's suggestions as I felt that if I chose ‘Ayrton broke his gear box', it could sound like he broke it deliberately. I also opted for the word 'spread' as 
Guzzo had clarified this was a message spreading over the radio and I felt ran did not work in this context.

“Ayrton's gear box broke" spread from post to post along the track.

Guzzo was happy with the first half of the sentence but would not budge on 'ran'.

"Ayrton's gear box broke" ran from post to post along the track.

I was not willing to use just 'ran' and so offered Guzzo another solution, it was longer than the Italian but was clearer in meaning.

"Ayrton's gear box broke" - the message ran from post to post along the track.

Guzzo was not happy with this option either and insisted that 'ran' worked in the context in English, saying he had seen 'ran 'used in this manner in a monastic poem.

"Ayrton's gear box broke" ran from post to post along the track.

After further discussions, Guzzo agreed on the final version above. Guzzo had not wanted to use spread as it had already been used in one of the previous sentences. I suggested changing the earlier use of the word, to allow for 'spread' to be used in this sentence instead.

“Ayrton's gear box broke" the news spread from post to post along the track.

Beco was the short story that involved the most rounds of feedback and it was also the story that Guzzo was least flexible with. He did not want to deviate from the Italian text even after long exchanges where we discussed certain elements that were not as effective in English. Despite our differing opinions, we were able to agree on a version that we were both happy with in the end.

Along with Guzzo's tendency to become stubborn about his preferences, I too have been stubborn about mine - not wanting to make changes to my first version because I felt it was just fine. Umberto Eco discusses translation as a form of endless negotiation, stating that:

Negotiation is a process by virtue of which, in order to get something, each party renounces something else, and at the end everybody feels satisfied since one cannot have anything. In this kind of negotiation there may be many parties: on one side, there is the original text, with its own rights, sometimes an author who claims right over the whole process, along with the cultural framework in which the original text was born; on the other side, there is the destination text, the cultural milieu in which it is expected to be read." ${ }^{30}$

${ }^{30}$ Umberto Eco, Mouse Or Rat? Translation as Negotiation (London: Orion, 2013),5. 
Both the author and the translator need to be aware that we are not really and hardly ever saying the same thing, it is an accepted and agreed upon lie, an illusion, of the prospect of passable equivalence. I learned that these negotiations pushed me to come up with alternatives and this, almost always, resulted in a better translation. I had to learn that my stubbornness was in fact hindering the translations process. That being said, I also had to learn to stand up for myself and my writing. Creative writing is an important aspect of literary translation, one that distinguishes it from many other forms of translation. It can be difficult to prioritize my writing when I am still learning to be confident in my choices as a translator but over the past two years I have become more so. It was imperative to find a balance between privileging my writing while still incorporating feedback from Guzzo in a meaningful way.

Many times, his suggestions - right or wrong that they might be - will force me to consider other and ultimately better ways to express the sentence and the outcome is much improved on my original translation. This specifically happens with sentences that I have not had any particular trouble with, and so have not looked over them in great detail. Guzzo's feedback, has forced me to re-examine these sentences. This back-and-forth process tends to push my translation, and ultimately the outcome is a better story. In the end this process, though difficult at times, resulted in the best version of the translations, and a high-quality version I do not believe I would necessarily have achieved otherwise.

Patience and compromise are imperative from both parties. For Guzzo and I this compromise is achieved through our shared vision for the final product. While we may not always agree on the micro details, we agree on what we want the translation to be. Guzzo and I share many of the same writing influences and we both have a similar stylistic element in our writing. I think this is one of the reasons this collaboration has been successful.

Throughout our writing, however, we are much more aware of the way in which our joint ideas and understandings enable us, via the crucible of our conversations and collaboration, to discover new meanings - meanings simply not available to us working alone. $^{31}$

Though it is possible that I would get close to the final version without Guzzo's input, there are certain things that never would have crossed my mind that he brings up and make sense. I also believe that having Guzzo's involvement from a very early stage has made a great difference to the final product in a way that would not have been possible if he had been brought

\footnotetext{
${ }^{31}$ Andrea A Lunsford, Writing Together: Collaboration in Theory and Practice (Bedford Bks St Martin's, 2011), 38 .
} 
in at a later point in the translation process - for example, just to review the more polished work, as is more common in the usual translator author relationship.

Perhaps it would be easier if Guzzo had less knowledge of English and therefore were less likely to put forward an opinion on certain aspects? When the author knows language 2 and culture 2 too well it ceases to be of help, and it becomes interference with the intellectual work and ultimately the IP of the translator. To what extent does the translator have authority over their translations? This is an interesting topic mostly beyond the scope of this thesis, but which did affect my translation process in one specific circumstance. This is an interesting topic mostly beyond the scope of this thesis, but which did affect my translation process in one specific circumstance. Throughout this collaboration, Guzzo has been respectful of my role as the translator and has trusted my opinion when it came to what works better in English. One exception was the story Beco. Above I have referenced the sections where it proved difficult to find a translation that Guzzo and I were both happy with. We have discussed previously the first paragraph of Beco and the following phrase in greater detail: "Ayrton ha perso le marce, era corso di posto in posto lungo tutta la pista”. Although I had full control over the final translations within my thesis, when they were to be included in the Journal of Italian Translation, Guzzo had to first sign them off too. In previous stories included in this journal, Guzzo had always accepted my preferred version. In the case of Beco, Guzzo felt strongly about certain passages and his English version took precedence over mine even when I disagreed with it, because it was considered to be his intellectual property, not mine. Venuti further explores this idea in The Scandals of Translation: Towards an Ethics of Difference, when he says "Copyright, the legal codes and conventions that govern the ownership of intellectual works describes a narrow space for translation... From the viewpoint of translators and translation, these limitations carry some troubling consequences, both economic and cultural". ${ }^{32}$ It can be difficult to find the balance between too much input where the translator can feel stifled and too little input where key elements have not been clarified. Though Guzzo has a very comprehensive knowledge of English, he does not have an idiomatic knowledge and at times this can cause issues and delay the process. On the other hand, the extensive back and

\footnotetext{
${ }^{32} \mathrm{He}$ gives a specific example: "He [Kundera] produced a third English version of his novel The Joke, which he cobbled together not just from his own English and French renderings, but also from the "many fine solutions" and the "great many faithful renderings and good formulations" in the previous translations (Kundera 1992: x). Whether the translators consented to Kundera's handling of their work remains unclear; the title page of his revision does not list their names. Copyright law permits Kundera to get away with his questionable uses of translation by giving him an exclusive right in works derived from his. The law underwrites his view that the author should be the sole arbiter of all interpretations of his writing". Lawrence Venuti, The Scandals of Translation: Towards an Ethics of Difference (London: Routledge, 1998), 47.
} 
forth created a valuable form of sustained peer-review. If Guzzo hadn't had an extensive knowledge of English, this would have made many of his observations rather surface level and less in depth.

All in all, I have found it helpful to have input at an earlier stage of translation allowing the translator to focus on finessing the translation after the author has expressed which areas, they have particular opinions about. It is interesting to note that many of the areas I thought to be potentially problematic were not the ones that required the most back and forth between the author and I. In these cases, where I felt unsure if I had understood the intention of the passage, Guzzo was more often happy with my translation and could confirm I had conveyed the meaning correctly. On the other hand, much time would instead be spent on passages he would highlight that I had considered to be relatively straightforward. This was one of the benefits of working so closely with the author from initial drafts.

It was also important to learn to communicate with Guzzo the types of suggestions that improved the translation rather than hindered it. With my first few translations, I was open to receiving any sort of feedback as this was my first project of this sort, I did not know of a better way to go about it but, as time went on, I was able to articulate more clearly what I needed in feedback and clarification from Guzzo.

As a novice translator, this learning process has been invaluable. It is true that this process has sometimes been lengthy and difficult but that is to be expected with any project of this nature. Working with an author in this manner has been a great opportunity and the advantages of gaining the experience of translaboration far outweigh the difficulties. Throughout this journey, I have learnt how and when I need to ask for feedback, when I need to compromise and when to trust my own instinct. Ultimately, it has been a process which has led me to discover the greatest of gifts - my voice as a translator. 


\section{Testing and Achieving Equivalence: My Final Say}

To a reader who has never been involved in translating some passages may seem to deal with very petty questions. But translating is a matter of petty questions much of the time. It is also a matter of big, general questions and-especially in the case of Umberto Eco - exhilarating encounters with the author.

- William Weaver (Pendulum Diary).

Forgetting the original, distancing from the author, privileging my writing in English, my journey, process, and final revisions.

As mentioned earlier, in the book of short stories Le radici del mare, the overarching theme across all the stories is 'the sea'. Guzzo is passionate about his love and fascination for the sea and the creatures that inhabit it. As this is one of Guzzo's main interests in and outside of his writing, he uses words ranging from technical nautical terms to flora and fauna to places and very specific time periods. Once I began working with Guzzo, it quickly became evident that I was unfamiliar with the majority of these terms in English and Italian, therefore it required quite a lot of initial research to get to grips with these terms and be able to use them correctly in this context. This covered various terms from simple ones, such a fishing pole, to very specific boat parts and scientific names of fish and underwater flora and fauna. Guzzo's engagement with my translation work was extremely valuable during this time as he was knowledgeable on the topic and was familiar with much of the content. This worked as a form of sustained peer-review, making sure the most appropriate choices were made.

Guzzo's precise use of this terminology is a key stylistic aspect throughout his writing, making it imperative that I worked as hard as I could towards achieving equivalence in the English translation.

As well as many of the technical terms and scientific names, there are instances where Guzzo has used very specialized terms that pertain to a certain region or time period - these posed a different sort of challenge as, in some instances, there was no precise translation and so an alternative solution was required.

In the following examples I marked my changes in blue and Guzzo's in red. 


\subsection{I pescatori di Cork: the fear of being unfaithful}

This was the first story I translated and with that came many expected trials and errors. While I had a generally good grasp of the Italian language before embarking on this project, I was unaware of many aspects that encompassed literary Italian and I was unable to scrutinize every aspect of the language in a way that is imperative in literary translation. I had never thought too deeply about how Italian works in comparison to English, but these differences became evident immediately.

In this first story I was so focused on understanding the Italian (every word, general as well as specific), that many other elements were left to the side and these early challenges and problems show in the final translation. Compared to some of my later translations, I believe it lacks concision and finesse. It is clear that I am grappling with the two languages rather than finding a happy balance. This is something that only came with time and practice. I did go back and revise some of the syntax later when I was collating the final versions but I did not wish to retranslate it in its entirety because it showed my process and progress clearly and was therefore of more use in terms of a true commentary.

As it was one my first translations, I was unsure of myself as a translator and I didn't have confidence in my own choices and decisions. Now, I have achieved a thorough familiarity with Guzzo's voice, style of writing and literary purpose as well as a more comprehensive knowledge of the subject matter. In addition, at this point I had not yet developed my own personal voice and style of writing in translation, and this led to a noticeable lack of cohesiveness throughout the story.

When it came to input from my professor Marco Sonzogni or Guzzo, I did not question the changes they suggested and did not hesitate to incorporate them into my working version, even if it wasn't something that necessarily worked better in the English language or felt fitting to my own writing style. Sonzogni often would urge me to examine these choices again - was it something that was improving the translation? Would it be my preference? While compromise is one of the most important elements in this process, I needed to find my opinion, too.

In most instances, I chose to stay close to the Italian, as I was not yet able to focus on translating the meaning and the tone. I was afraid if I didn't keep all elements of the Italian, I would be losing aspects of the text. I did not yet know that, at times, it is inevitable to lose something in order to achieve what works best. I wanted to make sure I was being faithful to Guzzo's work and this was the way I was able to achieve that in my first attempt at translating his stories. 
The original translation of I pescatori di Cork is full of elements that are not quite right. A good example of this is the title: initially I translated it literally as "The Fishermen of Cork". While this isn't necessarily incorrect, it doesn't sound as idiomatic as "The Fishermen from Cork." I made this change during the revision process, taking into consideration the tone and flow of the style I had developed while working through later translations.

My first attempt at translating this story was full of these sorts of problems. While many of these choices weren't grammatically wrong, it was clear that they didn't sound quite right either. I was far more focused on retaining all aspects of the Italian than translating a story that worked effectively in English. In the first few stories I aligned myself more closely with Lawrence Venuti's foreignizing theory. ${ }^{33}$ In The Translator's Invisibility Venuti "coin[s] the concept of foreignization, an approach to translation which seeks to resist fluency and highlights the fact that the text produced in the target culture is a translation." 34 I made sure that the syntax and grammar followed closely to that of the original Italian - even if this was not what I thought worked best in English. I felt that otherwise I wouldn't be retaining important elements of the text. I later realized that there are few instances outside of academia where the reader will have the privilege of reading both the source text and the translation and therefore will not know if the translator has changed the syntax or tense. On the other hand, they will notice if the text is disjointed or the syntax becomes wordy and confusing, which is a common problem when translating from Italian into English. The following is the first example:

Here is the original Italian text:

\footnotetext{
"Nuvole di pioggia".

"Come sarebbe a dire nuvole di pioggia?"

"Azzurre, dense e senza forma. Sembra il cielo e invece sono nuvole".
}

La stessa foschia avvolgeva il cielo e il mare. Dentro una fitta cortina di vapore due uomini manovravano una Lancia sottile come un fuscello, non si può dire quanto lontano dalla costa. L'orizzonte era quasi scomparso: sembrava che la loro barca navigasse nell'aria.

"Mettiti il cappuccio, Jack, che viene..."

Jack si alzò sulla testa il cappuccio della cerata. Entrambi sapevano che non c'era riparo da quello

che stava per venire. Stavolta non andavano a caccia del kerke, come due mesi prima.

"Tre miglia al largo della costa di Kassiclanagh: i nostri calcoli erano esatti, allora, e l'abbiamo visto. Gli altri pensino pure quello che vogliono, ma noi sappiamo che l'abbiamo visto".

\footnotetext{
${ }^{33}$ Lawrence Venuti, The Translator's Invisibility: A History of Translation (London and New York: Routledge, 1995).

${ }^{34}$ Silvia Kadiu, "Visibility and Ethics: Lawrence Venuti's Foreignizing Approach," in Reflexive Translation Studies: Translation as Critical Reflection (UCL Press: 2019): 21.
} 
Il mare si era aperto all'improvviso per mostrare un dorso grande quanto una collina e tentacoli lunghi come la strada da Cork al villaggio più vicino.

"Dio sa come siamo qui per raccontarlo".

"Ma stavolta è ancora più terribile. È la madre di tutte le volte. Che Dio ci protegga..."

Jack Evans e Sean Morrissey erano pescatori. Ma pescatori di una specie particolare. Loro uscivano a pescare mostri marini. In materia erano la massima autorità del paese, forse dell'intera contea. Possedevano centinaia di libri e manoscritti e ogni anno compivano decine di spedizioni. Una volta erano arrivati fino in Islanda per riunirsi con gli esperti locali nell'insenatura di un fiordo e scambiarsi

notizie sui mostri dei mari del nord. Ma stavolta era diverso. Il giorno precedente, un'ora prima del tramonto, erano partiti da Cork con una faccia strana, come se andassero a incontrare il loro destino.

And this is how I first translated it:

"Rain clouds".

"How do you figure out rain clouds?"

"Blue, dense and without form. They seem like the sky and instead they are clouds".

The same mist enveloped the sky and the sea. In the thick curtain fog two men gently maneuvered the launch as thin as a twig. It was hard to say how far from the coast they were. The horizon had almost disappeared: it appeared as if their boat was sailing through the air..

"Put on your hood, Jack, it's coming..."

Jack put the hood of his rain jacket on. They both knew that there was no refuge for what was about to come. This time they were not going to chase the kerke as they had two months before. "Three miles off the coast of Kassiclanagh: our calculations were accurate, then, and we saw it. The others can think what they like but, but we know we know that we saw it."

Suddenly, the sea had opened up to show a fin the size of a hill and tentacles long as the road from Cork to the nearest village.

"God knows how we are here to tell the tale".

"But this time it is even more terrible. The mother of all the other times. May god protect us..."

Jack Evans and Sean Morrissey were fishermen. But a certain type of fishermen.

They sought to catch sea monsters. On this topic they were the most knowledgeable in the town and possibly in the entire county. They owned hundreds of books and manuscripts on the matter and every year they would carry out dozens of expeditions. One time they went as far as Iceland to meet with local experts deep into the fiords and exchange information on northern sea monsters. But this time felt different. The day before, an hour before sunset, they left Cork with a strange expression on their face, as if they were leaving to face their destiny.

My second draft read as follows, and I have highlighted the changes:

"Rain clouds".

"Rain clouds? Why?"

"Blue, dense and with no form. They seem like the sky and instead they are clouds".

The same mist enveloped the sky and the sea. In the thick curtain fog two men gently maneuvered a sailboat as if it were as delicate as a twig. It was hard to say how far from the coast they were. The horizon was barely visible: it appeared as if the boat were sailing through the air.

"Jack, put your hood on, it's coming..."

Jack put his rain jacket hood on. They both knew that there would be no shelter from what was coming. This time they were not going just to chase the kerke, as they had two months before. Our calculations were correct: it was three miles off the coast of Kassiclanagh. That's when we saw it. The others can think what they like but we know that we saw it." 
Suddenly, the sea had opened up to show a fin the size of a hill and tentacles long as the road from Cork to the nearest village.

"God knows how we are here to tell the tale."

"This time is going to be all the more terrifying. The mother of all the other times. May God protect us..."

Jack Evans and Sean Morrissey were fishermen. But they were a particular type of fishermen. their goal was to catch sea monsters. When it came to this topic they were the most knowledgeable in the whole town, perhaps even the whole country. They had hundreds of books and manuscripts on the matter and every year they carried out dozens of expeditions. One time they went as far as Iceland to meet with local experts deep in the fiords and exchange information on northern sea monsters. But this time felt different. The day before, an hour before sunset, they had left Cork with a strange expression on their faces, as if they were going to face their destiny.

As you can see, most of the changes were relatively minor - I was not rewriting the story but simply changing the elements that were not idiomatic in English and were, therefore, jarring to the reader. I think these changes made a significant difference to how the story reads. While this is an example from just the first paragraph, these sorts of changes were made throughout the story.

Here is another example of the changes I was beginning to make:

This is the original Italian:

In paese, nella piazza della pietra Dente di cane, poca gente - vecchi soprattutto - faceva a gara a contare i propri malanni, e adesso parlava dei bambini scomparsi e della spedizione partita per ritrovarli.

This is my first version:

In the town square Dente di cane (violet?), few people - mostly old people - competed for who had more ailments and now they also discussed the missing children and the expedition party that had been sent out to find them.

And this is how the text changed with Guzzo's suggestions. I have highlighted his changes in red:

In the square with the stone called "Dog tooth" few people - mostly old people - competed for the heaviest ailments and now they discussed the missing children and the expedition that had been sent out to find them.

Here is my next draft:

In the town, a few people would gather in the dog tooth square - mostly the elderly - and they would chat, competing for who had the most ailments, but now they discussed the missing children and the expedition that had been sent out to find them;

which then became:

A few people would habitually gather in the town square to chat, mostly the elderly competing for who had the most ailments, but today they discussed the missing children and the expedition that had been sent out to find them; 
and finally:

A few people would habitually gather in the Dogtooth stone square to chat, mostly the elderly competing for who had the most ailments, but today they discussed the missing children and the expedition that had been sent out to find them.

In this example, there was an issue of content. With Guzzo's use of pietra Dente di cane, I was unsure if it literally meant Dog tooth stone or if this was simply a name. I was also unsure if this was a real place, as this story is set in Cork, a place which I had little knowledge of and which may have, in fact, been home to a famous Dog tooth square. When researching this term, it came up with many options: there was a dog tooth violet, a dogtooth amethyst and it could also be an architectural feature. This did not clarify things in the slightest. In my initial translation, I opted for a literal translation as I felt this was the best option until Guzzo clarified if he was intending to use one of the other meanings. After further discussion with Guzzo, he confirmed that he meant there was a stone in the shape of a dog's tooth in the town square.

The second issue in this section was a syntactical problem. The sentence became confused in my first few attempts as I tried to follow the punctuation and syntax of the original. Only with frequent rereading and rethinking, was I able to rearrange the syntax in a way which flowed naturally for an English language audience.

I learnt that it was important to veer away from the Italian when needed but I still wanted to retain some of the oddities of style that make reading a book written in another language different. There are certain aspects that are unusual or are images that would not be typically found in books written in English. While these aspects are often not the most idiomatic and they will stand out to the reader as so, they add something different, something specific and enticing. They might even be the hallmark of a new great writer. One of Guzzo's strongest stylistic aspects are these oddities, creating peculiar and unexpected imagery. Even in Italian these are prominent, and it was, therefore, even more important to keep these intact. These are two examples that stood out as examples of unusual images. The first is in the Italian followed by my translation:

Sean Morrissey aveva paura, ma non rinunciò a inarcare le sopracciglia da pirata in un'occhiata di sfida.

Sean Morrissey was frightened, yet he raised his pirate eyebrows and looked defiantly at the creature.

I decided to keep "He raised his pirate eyebrows" because, while it is an odd image and certainly not a frequently used expression in English, I also believe it is neither confusing nor 
out of place in the context of the story but adds a particular flavour which would otherwise be lost. These atypical images are an element of Guzzo's style and therefore I believe it is important to retain this in the translation. Baker describes this as an element of cohesion: "statements about collocation are made in terms of what is typical or untypical rather than what is admissible or inadmissible. This means that there is no such thing as an impossible collocation. New and unusual combinations of words occur frequently, and we do not necessarily dismiss them as unacceptable". ${ }^{35}$ The difficulty with poetic language arises when deciding which collocation is deliberately new and unusual and therefore effective and which is just odd in English.

Here is another notable example:

Il sindaco O’Brady traballava come un pipistrello in coda al gruppetto.

O’Brady, the Mayor, skittered like a bat lagging behind the group.

I am conscious that 'skittered like a bat' is not commonly used in English but I still enjoyed the image, as I hope future readers will.

The next and final example is focused on the short poem that ended this story. Using fragments of poetry within his short stories is a recurrent element of this author's style in this collection and, at first, I approached it as simply translating more Guzzo.

This is Guzzo's Italian version as it appears in I pescatori di Cork, which is not one of the standard Heaney translations:

Ora il limbo sarà freddo bagliore di spazi remoti e amari. Lì anche i palmi di Cristo, non sanati, bruciano e non riescono a pescare.

This was my first attempt at translating the poem:

There will be a cold glow in limbo, now a distant, bitter place.

Even the palms of Christ can't heal, They burn, and cannot fish there

Guzzo did not comment on this, and I was unaware that it was not simply another Guzzo poem. However, in discussion with Dr Sonzogni, I later discovered it was Guzzo's Italian translation

\footnotetext{
${ }^{35}$ Mona Baker, In Other Words: a Coursebook on Translation Third Edition, (London: Routledge, 2018),57.
} 
of the final stanza of the Seamus Heaney poem 'Limbo'. The original Seamus Heaney poem reads as follows:

A cold glitter of souls

Through some far briny zone.

Even Christ's palms, unhealed,

Smart and cannot fish there.

Seamus Heaney, 'Limbo '(Wintering Out). ${ }^{36}$

Upon finding this out, I made sure to use the original poem rather than my translation of a translation, because Heaney's poem was Guzzo's inspiration and starting point and the literary influence and allusion would be captured for readers only through the use of the original text. In this case, Guzzo embraced the creativity of translation to better convey his vision for his story. The challenge here, for me as the translator was in identifying the original Heaney poem in order to make sure it was appropriately incorporated into my translation.

It has been an interesting exercise to look back on this first translation, as it has really illuminated how far I have come. It is clear to see how much of my focus was on comprehending the Italian text and my desire not to stray from the original text even in terms of grammar and syntax, in fear of missing a key element. I had not yet learnt to discern what parts of Guzzo's writing must remain intact in order to highlight important stylistic elements, or how forcing the English to behave in the same way as the Italian could in fact detract from the writing. The main element missing from this translation was cohesion and I am pleased to see this became a focus in later translations.

\subsection{La preda: striving for a cohesive voice}

The story explores the deep dark things that lie dormant inside us but come to the surface, when awakened. This is what is happening literally in the story with the "prey", but more importantly, this is a metaphor for what is happening to the main character throughout the story. The use of metaphor is a key stylistic choice by Guzzo, one that is very deliberate and is notable throughout many of these stories.

\footnotetext{
${ }^{36}$ Seamus Heaney. Wintering Out. (London: Faber and Faber, 1972), 58.
} 
The writing is rather dense and complex in the Italian original and this posed certain syntactical challenges, when trying to make the very long metaphorical sentences clear and poetic in English, rather than long winded and confusing.

Guzzo's writing clearly belongs to the Italian literary tradition. However, his stories are not thematically rooted in Italian culture. Guzzo draws much of his influence from outside Italy. Many of his stories are not set in Italy and even in the ones that are, the geographical setting is never a main aspect of his stories; this is one of the reasons I chose to translate this collection of short stories because it did not contain a host of cultural aspects that would be near impossible to convey to the target audience. Despite this, there were still a few local references. One of these that proved difficult to translate was trabucco, a very specific old fishing machine typical along the coast of Italy. ${ }^{37}$ This term was one that was most certainly specifically set in Italian culture and therefore had no comparable translation. Baker describes this as nonequivalence at word level this "means that the target language has no direct equivalent for a word which occurs in the source text". ${ }^{38}$

In this instance, I chose to not translate this word and add a footnote. I had thought about translating it as an old-fashioned fishing contraption or something of the sort but decided against this as I felt it was removing something, that while not crucial to the readers' understanding of the story, is, nevertheless, one of the aspects that differentiates this text from something that could have been written in English.

Here is the sentence where it appears in the Italian text:

Nessuno lo sapeva, a parte l'uomo, che ci aveva tenuto per anni il suo trabucco e l'aveva esplorata in lungo e in largo in apnea. Se non poteva andare lontano cercava almeno di andare a fondo.

The first draft of this sentence, where I tried to translate trabucco as best as I could is:

Nobody knew, except for the man, who had kept his old-fashioned fishing contraption and explored far and wide free diving. When he could not go far, he tried at least to go deep.

And this is the final translated text with trabucco left in Italian:

Nobody knew, except for the man, who had kept his trabucco there and explored that stretch of water, inch by inch, free diving.

\footnotetext{
${ }^{37}$ https://www.treccani.it/enciclopedia/trabucco \%28Enciclopedia-Italiana\%29/ (accessed February 22, 2019).

${ }^{38}$ Mona Baker, In Other Words: a Coursebook on Translation Third Edition,(London: Routledge, 2018), 19.
} 
In the same paragraph there was another word that took multiple versions to find a suitable solution; The sentence as it appears in the original Italian is:

Chiamavano quella zona "pelagosa", un singolare incrocio di mare e palude.

In the first translation of this sentence, I kept the word in the Italian:

That place was known as pelagosa, an intersection of sea and swamp.

After further thought, this is the final version I settled with:

They called that place saltmarsh, a strange intersection of sea and swamp.

The term here that was problematic was "pelagosa" from "pelago." 39 Once again, there was no translation for this specific word. Initially, I tried to keep the term in Italian, but it did not have the desired effect, making the sentence clumsy and unclear except to those with some knowledge of the original language. I also decided that using a footnote would be equally disruptive to the flow of the language. I had to take another approach. Ultimately, I decided to go with a freer translation settling on "saltmarsh" as I believed this retained the more poetic tone and left the reader with a distinct image in line with the author's intention.

The next example highlights how I began to work with the text to create a more natural and idiomatic flow while still retaining the meaning and tone of the original.

The original Italian sentence is:

Come in un mare piatto e indistinto, dove tutto è amico e tutto è ostile e ogni direzione è quella sbagliata.

Here is the first more literal translation:

Like a shadowy, still sea, where everything is friendly and everything is hostile and every direction is the wrong one.

This was the second version where I focused on making the second part of the sentence more poetic:

Like a shadowy, still sea where anything could be friend or foe and any direction could be the wrong one.

\footnotetext{
${ }^{39} \mathrm{https}: / /$ www.treccani.it/vocabolario/pelago (accessed February 22, 2019).
} 
And the final translation:

Like when the sea is shadowy and still, where anything could be friend or foe and any direction could be the wrong one.

I can see now how this story was a turning point in the development of my own personal translating style. Here, I started to focus on how it sounded in English, on conveying not only the meaning but also the tone, rhythm and aural nuances of the original. The poetic effect became as crucial as the storyline. In the early stories I translated I thought that making changes like these meant I was not being faithful to the original. However, the dense prose of this story forced me to be freer with the way I translated into English so that the poetry of the imagery could shine. I found that when I began to make these changes, I was able to work toward creating a cohesive tone, which was something that had been lacking in some of my earlier translations. On the one hand, I needed to develop my own voice in writing and part of that was creating my own specific tone for Guzzo in translation. However, I also needed to balance this with taking into account Guzzo's requirements.

The following example highlights the importance of compromise when collaborating with the author at a more intensive level while striving to maintain a cohesive tone. This is the passage in question in the original Italian:

Cose da scrivere con la maiuscola, questo voleva tirare a galla, un briciolo di meraviglia infantile nella pancia della sua preda.

Here is the first translation:

Something worthwhile writing - that's what he wanted brought to the surface - a crumb of childlike wonder in the belly of his prey.

This is second version with Guzzo's input, that became the final version:

Something worth writing in capital letters - that's what he wanted brought to the surface - a crumb of childlike wonder in the belly of his prey.

Guzzo was determined to keep the literal translation in this example and, as I didn't feel strongly that the language was awkward, I was content to follow his wishes. Guzzo uses this expression a number of times throughout his stories and so it was preferable to keep it as he liked it.

The following example, on the other hand, is evidence of when it was necessary to push back in the interests of the clarity of the text. The dilemma here arose from translating Italian idiom. Here is the idiom in the Italian text: 
Prima di capire doveva sbatterci la testa. Fracassarsi il muso e dal dolore di qualche dente caduto capire. Chissà per quanto, poi, chissà fino a che punto.

This is my first translation where I tried to keep the idiom intact:

Break his nose and by the pain of broken bones understand. Who knew for how long, then, who knows until when?

These were Guzzo's suggestions:

To break his jaw and then, by the pain of fallen teeth, to understand. Who knew for how long, anyway, who knew how deeply?

This was my second, freer version:

It was always like that. To get things right he had to get things wrong. He had to get hurt to be able to understand. And who knows for how long and to what extent.

Idioms are one of things I found hardest to translate effectively and, in this instance, the difficulty was compounded by the fact that Guzzo was not simply using an idiomatic saying but playing with it. The idiom focuses on fracassarsi la faccia and extends the metaphor. In English, a literal translation became heavy and confusing. In this case less was more and while the idiom is lost, instead I focused on tone and creating a simpler and sharper flow.

The final example I have chosen from La preda is the first paragraph. The beginning and endings of Guzzo's stories always provide challenges as they set the atmosphere and tone and are very tightly and intentionally crafted. This is something that is prevalent throughout Guzzo's collection of short stories and other works of literature, and in novels too, it is highlighted in the short stories as every word matters and every nuance matters. Giuliana Adamo comments on this in relation to the work of Italo Calvino: "Calvino's fundamental concept is that literary beginnings (and endings) are decisive because they delineate 'un mondo a se stante, autonomo, autosufficiente, un mondo ipotetico, uno dei tanti possibili, un'isola in un arcipelago, un corpo celeste in una galassia'. The literary beginning is the transition from the unlimited possibility of saying everything every possible way to saying only one thing in only one way". ${ }^{40}$ Guzzo also approaches beginnings in this way. The first paragraph of $L a$ preda is imbued with the undertones and nuances which hint at the crucial aspects of the tale.

The Italian text reads as follows:

\footnotetext{
${ }^{40}$ Giuliana, Adamo, "Twentieth-Century Recent Theories on Beginnings and Endings of Novels," Annali d'italianistica 18 (2000): 60.
} 
"Dio che pesca!". L'uomo sussultò per lo strattone che aveva dato. Tenne l'equilibrio, come deve un bravo pescatore, come lo tiene un uomo fatto, senza più conti aperti con la meraviglia. Restò in piedi e seppe che aveva messo a segno il colpo della vita. In un attimo svestì la zimarra della malasorte e l'attimo dopo era tutto orgoglio.

Gli occhi nerissimi avvamparono come tizzoni, il naso adunco luccicò preciso identico al becco di un rapace. Gli sembrava di aver agganciato le fondamenta della terra.

This is the first translation:

"God, what a catch!" The man was jerked forward by the powerful tug on the line. He held his footing, as a good fisherman does, as a grown-up man does who has seen it all. He stayed on his feet and knew that he was close to landing the catch of his life. One moment, he took off the mantle of misfortune and the next he was full of pride. He tore the mantle from the shoulders of misfortune and the next was full of pride.

Its darkest black eyes glowed like live coals and its hooked nose gleamed like the beak of a bird of prey. It seemed to be hooked into the foundations of the earth.

This is the second:

"God, what a catch!" The man was jerked forward by the powerful tug on the line. He kept his footing, as a good fisherman does, as a grown-up man does who has seen it all. He stayed on his feet and knew that he was close to landing the catch of his life. One moment, he took off the mantle of misfortune and the next he was full of pride.

Its jet-black eyes glowed like live coals and its hooked nose gleamed like the beak of a bird of prey. It seemed to be hooked into the foundations of the earth.

And this is the third and final version:

"God, what a catch!" The man was jerked forward by the powerful tug on the line. He kept his footing, as a good fisherman does, as a grown man who has seen it all does. He stayed on his feet and knew that he was close to landing the catch of his life. One moment, he took off the mantle of misfortune and the next he was full of pride. Its jet-black eyes glowed like live coals and its hooked nose gleamed like the beak of a bird of prey. He felt like he had hooked into the foundations of the earth.

There were some changes (highlighted in blue) which were largely cosmetic and were made over the versions to make it flow better in English and other changes which were made to try to clarify and crystallise the image. The part that was most difficult to replicate was "in un attimo svestì la zimarra della malasorte e l'attimo dopo era tutto orgoglio". Firstly, it was hard to find an appropriate translation for zimarra. The most accurate translation appeared to be 'cassock' but that didn't seem quite right, giving an impression in English of a priest's vestment which was out of place on a fisherman. Instead, I chose 'mantle' which seemed to work better with the context of the story and the metaphorical connotations.

This was the first story where I started to look at various different elements. My Italian had improved and while I still focused heavily on the Italian text, there was more of an emphasis 
on understanding meaning overall and how it worked in the context of the story. I was beginning to focus more on creating a cohesive tone. This is one of Guzzo's more abstract stories with a heavy slant towards poetic prose. The plot is simple and certainly not the focus of the story, highlighting instead the inner transformation of the character. These elements, which draw the reader's attention most strongly to Guzzo's characteristic tone and style, make this a story which it was important to shape carefully as something of a touchstone of his body of work.

This was the first translation in which I started to question all different elements of the text, how and why and Guzzo had made certain choices and what elements were most important to highlight in the English. This story had many sentences that easily could become long and convoluted forcing me to choose between keeping one element or another.

This shift in my translation process was very noticeable when I went back to look through my notes as this story was heavily annotated with a variety of inquisitive notes, rather than simply highlighting words I needed to look up as had been the case in my earlier translations. This was an important step forward in finding my voice as a translator. 


\subsection{La mano del diavolo: the author's whims to the translator's whims...}

La mano del diavolo was the first story I translated where I really focused heavily on the stylistic aspects of the translation. I continued to focus on how the English sounded without as much focus on the literal Italian. While I still obviously wanted it to be faithful to the original, I no longer felt the need to stick so closely to the grammar and syntax of the Italian in order to achieve a faithful translation. In fact, I found my translation would be more faithful to what Guzzo intended the reader to glean from the story if I focused on working it more effectively and seamlessly into the constructs of the English language. The idea of what constitutes a 'faithful translation' is something that has somewhat of a fraught history in translation studies. It is often defined in terms of 'domesticating' and 'foreignizing' or 'source oriented' and 'target oriented'. I believe that nothing in translation is black and white and finding somewhere in between can yield success. I did not want to apply one single translation lens to these stories instead I aimed to choose the best tactic for each individual scenario. Anna Colombi Gadd discusses finding this balance:

The initial choice, however, should not be overinterpreted: first of all, there is no such thing as a strict binary opposition between source- and target-orientedness, but rather a whole range of nuances lies in between; and secondly even if an overall choice towards one pole or the other has been made, it is not necessary, and not necessarily true, that every single lower-level decision be made in full accord with it. ${ }^{41}$

After almost two years translating Guzzo's work, I believed I had a good grasp of Guzzo's stylistic preferences; the words, the syntax and the themes he tended to favour. I began to gain confidence in my choices as a translator and in the style and tone I had created for Guzzo's stories in English. I now felt less tied to each word. I began to play around with various options pushing the translation further than I had previously felt comfortable doing. This shift also allowed me to follow Guzzo's suggestions less literally. Instead of taking his suggestions as gospel, I worked on writing a version that took his concerns into consideration while creating a work that was effective in English.

While honing my skills in creating a successful target translation, I also needed to incorporate Guzzo's distinctive stylistic element of specific word choices.

The following examples clearly highlight Mona Baker's categories of equivalence at word level: it was pertinent that the exact English equivalent was used. As Guzzo had been very

\footnotetext{
${ }^{41}$ Anna Gadd Colombi, Translation as Criticism: Elizabeth Jolley's Mr Scobie's Riddle (Cambridge Scholars Publishing, 2018), 16.
} 
conscious about which words he had chosen for the Italian text, so it was pertinent that I too chose words with the same precision. I made sure to opt for the more technical word, as Leonardo has chosen to do in the Italian knowing that, if he wanted it simplified, he would have chosen a simpler word in Italian. On a very few occasions, this was not the best solution as the English equivalent sounded out of place in the context or register of the story but, apart from these circumstances, it was always a priority to maintain this element of Guzzo's style.

There were a few elements of this story that proved difficult to translate accurately and effectively. This story is set in the 1500's and therefore, in true Guzzo fashion, this included many terms very specific to this time period which required extra care when translating. One of these words was giannizzero. This was not a word easily found in a dictionary and extra research and consultation with Guzzo was required. The English term is 'janissary', referring specifically to a member of the Turkish infantry forming the Sultan's guard between the 14th and 19th centuries. It is an uncommon and rarely used word in both languages. The context of the word makes it clear that it is some sort of guard but the historical detail will most likely be lost on readers in both the source and the target language. I deemed this to be an acceptable solution.

Another challenge was finding the correct term for cerusico. At first, I went with 'butcher' as this seemed the best choice but on further research and discussion with Guzzo 'barber-surgeon' was found to be the correct term to use. This term comes from the middle ages. As barbers had sharp razors, they were tasked not only with cutting hair but with amputating limbs if needed. These specific terms are a key stylistic choice in this story and typical of Guzzo's style in general, making it imperative that I get these words correct.

The term galea also required some thought. This type of boat is again specific to the time period the story in set in. Initially, I contemplated translating it simply as 'ship', but this was clearly not specific enough - there are many types of ships. I also debated using 'galea ship' as this word seemed to be used in English too - but without adding ship I feared it would be a term that was a little too obscure for the majority of readers. This was another instance where the opportunity to discuss my choices with the author enabled me to find a more convincing option, as he steered me towards using 'galley'. This is the most accurate translation for this type of ship powered by oarsmen.

These examples proved to be lexically challenging. The following example also shows Guzzo's characteristic use of nautical terminology. Here is the sentence in Italian: 
I cannoni aprirono il fuoco e uno dopo l'altro volarono via il rostro, le rembate, pezzi dell'aposticcio fino al tendale di poppa.

Followed by the English translation:

The cannons opened fire and one by one blew apart the rostrum, the forecastles, and sections of the outrigger right down to the canopy over the stern.

This sentence highlights the frequency with which Guzzo uses specific boat terms. I was unfamiliar with rostrum, forecastles and outrigger and therefore each of these words needed further research and to be vetted by Guzzo, so I could be sure that they were correct. This use of specific terminology is a key element in Guzzo's writing, so it was important that the same care was taken in the English.

This next example had various elements that were problematic lexically and syntactically as well as issues with tone and meaning. This is the original Italian text:

Vista da vicino, invece, la sua anima somigliava a un caos di forze elementari o un presagio di fine del mondo. Dune sgretolate al sole, torba e carbon fossile e vinaccia a fermentare, tracce e residui di una mutazione, il bolo d'ispidi bocconi avviato a percorrere sentieri segreti. Prima ancora che qualcuno la teorizzasse, nell'intimo della sua coscienza, don Miguel aveva fatto "tabula rasa". Adesso si portava in giro un'anima vuota.

Here was my first version:

Viewed up close, however his soul resembled a chaos of elementary forces or an omen of the end of the world. Dunes splintered under the sun, peat and coal and bad wine fermenting, the residue of a mutation, the bolus of prickly mouthfuls sent to wander down secret pathways. Before anyone could theorize, in the depths of his conscience he had wiped the slate clean. Now he carried around with him an empty soul.

This was Guzzo's input:

Viewed up close, instead, his soul resembled a chaos of elementary forces or an omen of the end of the world. Dunes splintered under the sun, peat and coal and grape pomace fermenting, trails and remains of a mutation; the bolus of shaggy mouthfuls sent to slide down secret pathways. Before anyone could theorise, in the depths of his conscience he had made a "tabula rasa". Now he carried around an empty soul.

Upon reflecting on Guzzo's suggestions I came up with this second version:

Viewed up close, however, his soul resembled a chaos of elementary forces or an omen of the end of the world. Dunes splintered under the sun, peat and coal, grape skins fermenting, debris and what remains after mutation, the bolus of thorny mouthfuls forced down secret pathways. Before anyone came up with the expression, in the depths of his conscience he had wiped the slate clean. Now he went about soulless.

My third translation after much thought and deliberation became: 
Viewed up close, however, his soul resembled a chaos of elementary forces or an omen from the end of the world. Dunes splintered under the sun, peat and coal, grape skins fermenting, debris and what remains after mutation, a thorny bolus hard to swallow but forced down secret pathways. Before anyone came up with the expression, in the depths of his conscience he had wiped the slate clean. Now he went about soulless.

While I felt it was much improved it still didn't read quite right, so I tried yet again, and this became my final translation:

Viewed up close, however, his soul resembled a chaos of elementary forces or an omen of the end of the world. Dunes disintegrated under the sun, peat and coal, grape skins fermenting, the residue of a mutation, a pellet of thorny mouthfuls forced down secret pathways. Before anyone came up with the expression, in the depths of his conscience he had "wiped the slate clean". Now he carried around a vacant soul.

The first, and most troubling issue was il bolo d'ispidi bocconi. Here I had difficulty understanding what exactly a 'prickly bolus' was in the context of this sentence as well as deciphering the greater meaning of the passage as a whole. This was an instance where having access to the author was particularly useful. Guzzo explained he "wanted to say that Don Miguel has faced sad events in his life, but he is managing to handle them, to transform them in something positive, constructive, to 'digest' them in a way. Of course, this means he himself is transforming".

Sentences like this are typical in Guzzo writing, where he has used this sequence of images to highlight Miguel's metamorphosis. Here again I had to decide if I wanted to retain the image Guzzo had created or opt for something a little different. Tim Parks discusses this kind of choice that the translator has to make: "by looking at original and translation side by side and identifying those places where translation turned out to be especially difficult, we can arrive at a better appreciation of the original's qualities and, simultaneously of the two phenomena we call translation and literature". ${ }^{42}$ In this particular situation I believe this particular choice of words needed to remain - these oddities and very specific terms are signature to Guzzo's style. For the term vinaccia also was hard to find an equivalent as vinaccia can be translated as a variety of things - it can be a colour, or bad wine, as well as being a specific oenology term translated in English as marc or pomace to mean the pulp of the grapes. None of these seemed to be right, I opted for grape skins as I felt this retained the meaning without being too technical.

Guzzo initially was rather persistent in his desire to keep tabula rasa in the Latin but in this case, I didn't believe it was the best option. Firstly, tabula rasa is not a very common term

\footnotetext{
${ }^{42}$ Tim Parks, Translating Style, A Literary Approach to Translation, A Translation Approach to Literature Second Edition (New York, Routledge, 2014), 14.
} 
in New Zealand English and therefore it may need a footnote or some other way to explain what it meant, especially when there is an equivalent in English that works well in the context of the sentence. It may be important to note that this term is less known in New Zealand English, and it is more commonly used in other parts of the English-speaking world. I have made this choice keeping as many English readers in mind as possible. I had chosen to translate prima ancora che qualcuno la teorizzasse, as before anyone came up with the expression, so then it became all the more important to keep wipe the slate clean in English. This was already an elaborate metaphor with many elements and I felt it was important to prioritize meaning for the target language reader.

The following example displays the stylistic choices involved in creating tone in translation. Here I wanted to make sure the final version worked best in English. Here is the original text in Italian:

Non protestò, e non per indifferenza o eroismo o sete di martirio. Non gli dispiaceva. Scontando la sua pena, nel mentre, aveva imparato la virtù delle maree. Passare e lasciarsi attraversare. Ora le cose meno familiari, quelle che meno gli appartenevano, erano diventate la sua vita. Restò invischiato nei festeggiamenti il minimo indispensabile: il chiasso dei banchetti e l'odore penetrante di spezie gli davano alla testa. Non gliene importava niente. Voleva celebrare soltanto se stesso. E la "moira".

This was my first translation:

He didn't protest and not out of indifference or heroism or the desire to be a martyr. He didn't mind. While he had served his sentence, he had learned the value of the tides. To let it all go. Now the things that had once been least familiar, that had not belonged, now had become his life. He was as uninvolved in the celebrations as possible. The din from the banquet and the sharp/penetrating smell of the spices went to his head. He didn't care. He wanted to celebrate by himself. And the will of gods.

These were Guzzo's suggestions for this section:

He didn't protest, and not for indifference or heroism or wish to be a martyr. He didn't mind. While he was serving his sentence, he had learned the virtue of tides. To pass and be passed through. The things once least familiar, that least belonged to him, had now become his life. He got tangled in celebrations as little as he could: the din from the banquet and the sharp smell of the spices went to his head. He didn't care. He wanted to celebrate himself and the "moira".

And this is the final version, taking into consideration Guzzo's points but still remaining faithful to my English version too:

He didn't protest, it was not out of indifference or heroism or any desire to be a martyr. $\mathrm{He}$ didn't care. While serving his sentence, he had learned to be like the tide: to ebb and flow, to come and go. The things that once had not been familiar to him, that had not been his, had now become his life. His involvement with celebrations was as short as it could be: the din from the banquet and the sharp smell of the spices went to his head. He didn't care. He wanted to celebrate his achievement only. And the moira. 
This example highlights stylistic and lexical issues. It was important to Guzzo that the term 'Moira' was not translated but instead left in the original Greek, as this was clearly deliberate in the Italian original too. In this instance I chose to add a footnote with the meaning and Guzzo was happy with this option. With this sentence aveva imparato la virtù delle maree. Passare $e$ lasciarsi attraversare in my second version I opted for a more poetic interpretation after trying more literal ones and finding it became convoluted and confusing. I believe this was the right choice in this scenario. In the second version of La Mano de diavolo, I made the conscious decision to pursue more liberal choices and changes, focusing more on the English text and what would work best in the target language.

The following example highlights another example of dealing with the differences between English and Italian. Here is the example in Italian:

Qualcosa gli premeva su per l'esofago e s'era fermato a un centimetro dalla bocca.

Initially I tried to translate this literally:

Something pressed up against his oesophagus stopping a centimetre from his mouth. Guzzo provided his input:

Something was going up through the oesophagus and stopped an inch before his mouth.

I was not content with my first version therefore opting for a more liberal translation for my second version:

His stomach turned as he tried to speak, there was a lump in his throat.

This was one of the recurring challenges between the two languages that came up in the majority of stories. In Italian, body parts are often very specific, whereas in English the specific terms are used more in medical situations, while colloquially and in literature the more general term would be used. I felt that 'oesophagus' was out of place in this context and choose to use throat instead. I found this particular sentence very difficult to translate literally, instead opting for a version that kept the meaning of the sentence but used a more idiomatic expression in English. Parks discusses these choices, stating that: "the translator's sensitivity to the language and context of the original leads to an assessment of its intentions, and it is to those that he then 
strives to be faithful". ${ }^{43}$ Ultimately this is what lead me to my decision in this example. I wanted to be faithful to Guzzo's intentions.

The penultimate example I want to discuss from La mano del diavolo focuses on the sorts of changes I began to make when tone and style became paramount. I could now see the importance of focusing equally on meaning and style. This is the original Italian:

I Turchi che restavano padroni del campo e vagavano e prendevano bottino e non andavano da nessuna parte. Andavano a caccia di cristiani e i cristiani non volevano farsi prendere, e allora succedevano le cose che lui non sopportava. Per ore, con sprezzo. E sempre più disgusto e stanchezza. Fino a una pace strana, che sapeva di distruzione.

Here is my first translation:

The Turks continued as masters of the field wandered about collected their spoils and didn't go anywhere else. They went to hunt Christians, but the Christians did not want to get caught and then he could not bear what followed. For hours, with contempt. Further disgust, further disgust, further fatigue. It became strangely peaceful with destruction in the air.

Guzzo had extensive suggestions for this segment:

The Turks that came out as the masters of the battlefield and wandered about and collected their spoils and weren't going anywhere. They went to hunt Christians, but the Christians did not want to get caught and then things happened that he could not bear. For hours, with contempt. With more and more disgust, more and more fatigue. Until a strange peace set in, with destruction in the air.

My aim with my second version was to loosen up the syntax and make it more accessible:

The Turks that had won on the battlefield and having collected their spoils weren't going anywhere. They went to hunt Christians, but the Christians did not want to be caught and the things that he disliked started to happen. Hours and hours of contempt. Further disgust and fatigue. Despite the destruction in the air, a strange sense of peace had set in.

My third and final version combined Guzzo's input with my desire for it to flow in English:

The Turks remained as victors on the battlefield wandering around collecting their spoils and not going anywhere. They went hunting Christians, but the Christians did not want to be caught and that was when the things he couldn't bear happened. For hours, and with contempt. With ever increasing disgust and fatigue. Until finally a strange peace that smelt of destruction set in.

This passage initially posed syntactical problems. In my first attempt, the English became confusing. Therefore, in my second attempt I tried to address this issue by simplifying things

\footnotetext{
${ }^{43}$ Tim Parks, Translating Style, A Literary Approach to Translation, A Translation Approach to Literature Second Edition (New York, Routledge, 2014), 9.
} 
in turn causing another issue of compromising the meaning. For the third attempt, I focused on the meaning and the getting the sequence of tenses right as this was something that Guzzo has chosen very carefully in the Italian. The third version I believe proved to be the clearest. The other difficulty here was the use of sapere in the last sentence. In Italian sapere can be used in many different ways and while it often means 'to know' it can also be used in relation to 'taste' or 'smell', adding a different layer of nuance. Mona Baker describes this translation issue as "a single word which consists of a single morpheme can sometimes express a more complex set of meanings than a whole sentence". ${ }^{44}$ Originally, I hadn't attempted to add this into my English translation but on further reflection I felt it was necessary. So, I opted to go with 'smell' because I believe this is the most idiomatic choice.

My final example for this story deals with the use of idiom in translation:

This is the expression in Italian as it appears in the original text:

Meglio godersi la luna in quinto decimo, lucente come fosse giorno.

Here is my initial translation:

Better to enjoy the moon in fifth tenth, bright as day.

This is what Guzzo suggested:

Better to enjoy the moon in its fifteenth parade, bright as day.

Here is my second attempt:

Better to enjoy the moon, bright as day in the sky for the fifteenth time in the month.

Followed by my third version:

Better to enjoy the moon, bright as day as it made its way through the sky for the fifteenth day after the new moon.

It seemed too wordy and convoluted so I tried to pare it back for my fourth version:

Better to enjoy the full moon, bright as day in the sky.

Though my fourth option worked well in English, I felt it was perhaps too simplistic and did not portray the full extent of the Italian. My final version was a compromise between two:

\footnotetext{
${ }^{44}$ Mona Baker, In Other Words: a Coursebook on Translation Third Edition (London, Routledge, 2018), 20.
} 
"Better to enjoy the mid-month moon, bright as day in the sky."

Here the issue was trying to find an English equivalent to the Italian expression quinto decimo. There are just some words and expressions in Italian for which there is no equivalent in English. Guzzo clarified what he intended with this passage: "I want to say that the moon was making its fifteenth monthly passage through the sky, that night. in quintodecimo or in quintadecima is a specific expression."

While this was helpful and it allowed me to clarify this image, I could not find any English equivalent. In English it would be more common just to describe it as a full moon. I needed to decide if I wanted to keep some semblance of the specific expression Guzzo has chosen to use, though it would make the sentence longer in English or to disregard it and opt for something that would be clearer and simpler to the target language audience. Mona Baker describes this as pragmatic equivalence stating that "like any writer, a translator has to take account of the range of knowledge available to his or her target readers and of the expectations they are likely to have about such things". ${ }^{45}$ It was important for me to take into consideration if this was something that would be clear to the target language audience.

Another similar example to note with this story is that the main character Miguel is loosely based on the Spanish writer Miguel de Cervantes. This is something that a typical English speaking/reading audience would probably not pick up on as Cervantes' works are not so widely known in the English-speaking world. The potential loss of this allusion does not affect the readers' understanding of the story though perhaps some of the nuance will be lost. As translator, I felt that this was an acceptable loss in order to maintain the fluidity of the text. I contemplated adding this as a footnote but was unsure where it would be most relevant and not intrusive.

La preda was a turning point in my translation journey, it was when I began to trust my intuition and embrace the creative process that is key to creating a great literary text in another language. In La mano del diavolo, I started to see myself as the author of the English text.

\footnotetext{
${ }^{45}$ Mona Baker, In Other Words: a Coursebook on Translation Third Edition (London Routledge, 2018), 239.
} 


\subsection{Il vento se ne infischia: The translator as author}

Il vento se ne infischia was one of the final stories I translated, and it was also the first story where I primarily focused on my English translations putting the Italian second. I was far bolder with my choices and my aim was to write a story that worked in English. I finally felt confident in my choices and my voice as a translator and no longer felt the need to stick to the Italian in order to convey meaning. I had built a relationship with Guzzo and was more comfortable with our mode of communication and with that I was able to better express what was helpful input and what was less so. I had a good grasp of his stylistic tendencies and had in turn created my own stylistic preferences when translating his work into English. The following examples highlight the different aspects I was now putting into question and my thought process behind resolving these translation issues. There was a greater emphasis on creating a cohesive tone between the Italian and the English texts.

\section{Marcantonio:}

This is as a moniker of sorts for John - one of the main characters - in Italian this is an old fashioned but popular expression to describe someone who is tall, strong, handsome and imposing. ${ }^{46}$

This has posed one of the most difficult challenges to find an accurate equivalent for. It is used numerous times throughout the story, making it all the more important to find something that works in English. The most common translations I found were 'wide bodied', 'big guy' 'hefty fellow' and 'strapping man'. What was most problematic about these translations was that while they accurately described what marcantonio meant, they did not portray the idiomatic aspect. This led me to try to come up with something of my own. Initially I tried out 'Big John', but I wasn't convinced this worked well. I also attempted to use 'Herculean John' or 'John the Hercules', trying to encompass the more classical aspect but while this worked in some instances it didn't work in all of them. Guzzo suggested 'John the hunk' but again this didn't work in all instances throughout the story, nor did it match the general tone of this more sinister story. I also considered leaving the term in the source language and using a footnote to describe what it is, but I didn't think this was a viable option

\footnotetext{
46 “marcantònio s. m. (f. -a) [dal nome di Marco Antonio, triunviro dell'antica Roma (82 a. C. - 30 a. C.)], pop. - Persona grande e grossa, dall'aspetto florido e robusto: mi si parò innanzi un $\mathrm{m}$. alto due metri. Con riferimento a donna, è usato spec. nella locuz. un pezzo (o un bel pezzo) di marcantonia". https://www.treccani.it/vocabolario/marcantonio/\#: : text=\%2Da\%3B\%20pl.,\%2C\%20colosso\%2C\%20(fam.) (accessed 11 March 2020).
} 
in this case. Firstly, it is used numerous times throughout the text so this would not be ideal and secondly because, in this instance, it is not a specific object that needs describing but an element of the character.

I toyed with the idea of leaving it out altogether, but I was sure there must be a way to incorporate it, at least in some way. Marcantonio is used five times throughout this story and ultimately, I found a solution that only worked for two of five instances. I chose to use the word 'macho' as I believe it conveys the idea of a strong, manly man. It is a word that did not distract from the sentences, this was something that had proved difficult to find. I used 'macho' in the first instance that marcantonio appears in the text:

And then on the edge of the dance floor this smooth-talking macho guy had introduced himself and she had let herself be seduced.

It was imperative that I found a solution that worked for at least the first time the term is used, as this is an element of John's character. I chose to use 'macho' for the following sentence as well because it fit nicely in the context of the phrase:

John, the macho guy, slept with the lights on. And more often he wouldn't sleep.

In the other three examples marcantonio is used as part of name, almost. This is what proved particularly difficult find in an English equivalent, as whichever word I tried, it always appeared to detract from the sentence and seemed incongruous with the context of the rest of the sentence, for example in this example:

When his brain cleared, John understood that he had pulled through.

The addition of 'John the macho guy' or 'macho john', just adds an unnecessary extra element to the sentence, without adding value.

I also believe another issue with finding an acceptable equivalent lies in the name itself 'John'. It is one of the most common English names and not one that is synonymous with strength or manly-ness, if it had been a name more like, Chad or Brad it may have been easier to find something that worked better: for example I believe 'Chad the bloke' or 'Brad the stud' sound better than 'John the stud'. This is not something would have come up in the original Italian text as 'John' is not an Italian name. I hope to find a solution that is more suitable for every example. 
Another element that I was mindful of in this story in particular was way the use of pronouns differs between English and Italian. In English this is something that has to be very clear otherwise meaning is lost. While it is not as imperative in Italian as in the gendered language, it is easier to follow who is doing what by the agreement, in English it needs to be clear who is stabbing who and who killed who. In this story, in particular, this was something that proved particularly problematic. The story flicked between Jane and John and they both used the third person pronoun and verb structure. When translated into the English, it was important to make the pronoun distinction crystal clear. Baker describes this as cohesion:

One of the most common patterns of establishing chains of reference in English and a number of other languages is to mention a participant explicitly in the first instance, for example by name or title, and then use a pronoun to refer back to the same participant in the immediate context. Languages that have number and gender distinctions in their pronoun system are less constrained in using this cohesive device, since different pronouns can be used to refer to different entities within a text with less possibility of confusion. ${ }^{47}$

This grammatical difference between English and Italian was clearly displayed in Il vento se ne infischia and was something I had to be very aware of from the beginning of the translation process.

While grappling with the grammar was a large part of the effort involved in this translation, getting the right tone was equally important as it was a lot more concrete and there was a pronounced sense of immediacy. Many of Guzzo's other stories have a greater sense of whimsy, tending to be more abstract and philosophical whereas Il vento se ne infischia has more of a linear storyline. This seems to be a theme for his longer stories (probably necessary, you can't have twenty pages of poetic wonderings with no plot). The greater focus on plot, at times makes it easier for the reader to follow the story but there is also less room for ambiguity as it needs to be clear to the reader what is happening and less can be left up to interpretation. It required multiple versions to get the right tone. It is also interesting to note that this stylistic change was clear in the syntax. Guzzo opted for shorter more concise sentences where he usually tends to favour a longer more descriptive syntax, focusing more on the internal thoughts of a character rather than action and plot.

I tried more literal translations and freer translations to try and find a version that best reflected the Italian original. The first example from Il vento se ne infischia highlights the grammatical

\footnotetext{
${ }^{47}$ Mona Baker, In Other Words: a Coursebook on Translation Third Edition (London: Routledge, 2018), 195.
} 
differences between English and Italian and how the two languages exploit the grammar in a literary context. This is the one of the opening paragraphs in the original Italian:

Avevano ballato, un lento e due jive, e lui le aveva sussurrato qualche parola appena un po' più audace e lei si era fatta convincere a seguirlo sulla sua barca. Si erano baciati sul molo e poi lui l'aveva presa in braccio e lei aveva pensato che sarebbe stato bello fare l'amore al largo. Le era piaciuto e lui aveva cominciato a parlarle di fughe e posti di fate mentre fumavano la sigaretta di rito.

In my first translation I chose to keep the tenses the same:

They had danced, one slow dance and two jives, and he had whispered a few bold words and she had let him convince her to follow him on to his boat. They had kissed on the pier and he had taken her in his arms and she had thought that it would be nice to make love out at sea. She had liked him and he had started to speak of escaping and enchanted places while they smoked the ritual cigarette. There must have been something strong in it, he had started to call her princess and then she hadn't remembered anything else.

Here is my second version, a slight change to the first:

They'd danced, one slow dance and two jives, and he'd whispered a few bold words and she had let him convince her to follow him on to his boat. They'd kissed on the pier and he'd taken her in his arms and she'd thought that it would be nice to make love out at sea. She'd liked him and he'd started to speak of escaping and enchanted places while they smoked the ritual cigarette. There must have been something strong in it, he'd started to call her princess and then she hadn't remembered anything else.

My third and final version felt the most appropriate in this instance:

They danced, one slow dance and two jives, and then he whispered a few bold words and she agreed to follow him on to his boat. They kissed on the pier and then he took her in his arms, and she thought that it would be nice to make love out at sea. She liked it and he started to talk about escaping to enchanted places while they smoked the ritual cigarette. There must have been something strong in it. He started to call her 'princess,' and then she didn't remember anything else.

One of the first decisions I had to make when translating this story was a grammatical choice.

In the Italian Guzzo has chosen to use the trapassato prossimo throughout. This is a common issue when translating between English and Italian as explained by William Weaver in relation to translating Eco:

I have been noticing, more and more, how Eco uses the perfect and the pluperfect where, in English, we would use the simple past tense. There are three temporal levels of narration: the present... the recent past... and remoter pasts. These past tenses will have to be carefully scrutinized as I go over the text. ${ }^{48}$

${ }^{48}$ William Weaver, "Pendulum Diary," Southwest Review 75, no. 2 (1990): 164. 
In the English translation of Il vento se ne infischia initially I, too, chose to use the pluperfect but it was not the best choice, as it became cumbersome. I tried to remedy this by using the contracted version but ultimately, I chose the simple past instead. My reasoning for this was that I felt this sounded best in English, but also because the meaning remained uncompromised. In Italian, the sequence of tenses is more set in stone, whereas in English the simple past was clear enough for most of the passage and the flow worked better. In the first version of my translation above, the continued use of the auxiliary verb is repetitive and clunky. Taking into account Guzzo's literary influences such as Hemingway, I opted to follow the simple use of past tenses where possible. Where the pluperfect was definitely needed for clarity of meaning, I made sure to use it as in this section in the above example: "There must have been something strong in it". Here I felt that it needed to be kept in the pluperfect.

Once I had settled on what tense to use, I turned my attention to word choice. The next example focuses on finding the right word. Here is the Italian text:

Si ripararono sotto una tettoia di filze e tubetti di bambù. Riguardarono, dietro di loro, la collina che digradava fino al mare. Poi l'uomo fece cigolare una porta traballante. Entrò in una stanza, col soffitto basso e piuttosto buia. Buttò la sacca sul pavimento e lo zaino su un divano che tossì polvere, e buttò un sorriso nella stanza.

This was my first translation:

They sheltered under a roof made of bamboo and raffia. They looked back, behind them at the hills that sloped down towards the sea. The door creaked and shook as the man opened it. He went into a low ceilinged dimly lit room. He threw the bag on the ground and the backpack on the couch, that coughed out dust, and threw a smile into the room.

In my second translation I focused on making changes to the last sentence:

They sheltered under some sort of roof made of bamboo and raffia. They looked back, behind them at the hills that sloped down towards the sea. The door creaked and shook as the man opened it. He went into a low ceilinged dimly lit room. He threw the bag on the ground and the backpack on the couch that coughed out dust as he did so, he smiled as he entered the room.

This was Guzzo's input:

They sheltered under some sort of canopy made up of bamboo and raffia. They looked back, behind them, at the hill that sloped down towards the sea. The door creaked and shook as the man opened it. He went into a low ceilinged dimly lit room. He threw the bag on the ground and the backpack on the couch, that coughed out dust in return; he smiled as he entered the room.

My third translation shows further changes to the last sentence:

They sheltered under some sort of thatch made of bamboo and raffia. They looked behind them at the hill that sloped down towards the sea. The door creaked and shook as the man opened it. 
He went into a low ceilinged dimly lit room. He smiled as he entered the room, putting the bag on the ground and as he threw the backpack on the couch it coughed up dust.

My final version shows the change in the first sentence:

They sheltered under some sort of bamboo and raffia awning. They looked behind them at the hill that sloped down towards the sea. The door creaked and shook as the man opened it. He went into a low ceilinged dimly lit room. He smiled as he entered the room, putting the bag on the ground and as he threw the backpack on the couch it coughed up dust.

This sequence of revisions highlights an issue with content and imagery. Mona Baker refers to this as a problem of collocation:

The phraseology and the collocational and grammatical patterning of the target version may and usually do - have to conform to target-language norms, but even then, the translation may still sound foreign or clumsy. Worse still, it may not even make sense to the target reader. ${ }^{49}$

This section included images and descriptions in the source language which were particularly striking and unusual. To successfully convey these impressions, I needed to focus on the target language norms and use convincing English grammatical patterning even if that meant losing something from the original version. Firstly, I had to find an appropriate translation for tettoia. The most common translation would be canopy. Guzzo was in favour of this option but I was not convinced this was the best choice, I felt it didn't work in the context as canopy is more often used to describe a canopy of trees. Initially, I tried roof but that wasn't accurate enough. In the end awning seemed to be the best option. The second part of the sentence was more problematic as the syntax and the imagery were not working in English. I loved this sentence in the Italian, but it required some more work for it to work in English. My first translation was clunky and did not highlight Guzzo's lovely image. In my first version I tried to keep "buttò un sorriso nella stanza" but I felt the image did not translate well so opted for the simpler "he smiled as he entered the room". I also decided to change the syntax structure - starting with "he smiled" instead and making each part of the image clear.

This next example focuses on the changes made to the final paragraphs in this story; focusing on Guzzo's use of tone in this section and the ways in which I made these stylistic choices effective in the English translation. Here is the Italian text:

\footnotetext{
${ }^{49}$ Mona Baker, In Other Words: a Coursebook on Translation Third Edition (London: Routledge, 2018), 124.
} 
E lei invece chiedeva di essere libera. Era vita, come vento, e non si poteva fermare. Gli chiedeva di restare solo. Di assuefarsi alla solitudine, come vincere la morte, e consegnarsi al flusso incoerente delle sue visioni, di tuffarsi tra i gridi e le voci, le ombre e i sogni. E non domarli, non racchiuderli, lasciarsi trasportare.

Sentì tirare, all'altezza del fianco, dov'era la sua ferita. Vide gli orli divaricarsi e il primo scorcio di un abisso. Senza sangue, stellato, nero.

Un attimo dopo le era addosso. Le mani intorno al collo, sulla pelle sottile, stringevano. La guardò fischiare dalla gola, gonfiarsi e gesticolare, senza ridere né piangere, senza provare emozioni.

Pensava solo, con freddezza. Era quello che doveva fare.

Poteva farlo bene. Ancora un po'. Non troppo.

L'eccitazione, esclusa a forza dal cervello, si prendeva tutto il resto.

Gli occhi e le tempie e le punte delle dita gli pulsavano. Le pupille dilatate guardavano attraverso una

patina opaca. Tutto diventava sempre più grande e poi sempre più piccolo. Più grande, all'improvviso, e poi di nuovo più piccolo, sempre più in fretta, come in un film accelerato. E intanto il contagio cresceva, avanzava e occupava terreno, fino al centro degli impulsi.

Un'ondata rovente gli allagò il cervello. Vorticava, impetuosa, contro i piloni corrosi del suo buon senso. Un vento, una brezza infernale gli intronò nella testa.

Il taglio sul fianco gli tirava e la sutura di fortuna sembrava sul punto di cedere. Notò troppo tardi come un dettaglio fuori campo, un luccichio.

La sua mano che impugnava qualcosa, senza più controllo, e poi oscillando sferrava il colpo.

Un fendente.

Un rumore netto, una sferzata tagliente nell'aria.

Gli si aprì uno squarcio e il sangue di lei ci schizzò ancora caldo e la faccia ci si impresse, ferma.

This is my first translation:

It was her instead that was asking to be free. It was life, like the wind, and you couldn't stop it. He asked to be alone. To get used to solitude, how to overcome death and surrender to the inconsistent flow of his visions, to plunge into the screams and voices, shadows and dreams. Don't tame them, don't keep them captive, surrender.

He felt something pull at his side, where his wound was. He saw the brink of an open abyss. No blood, starry, black.

A moment later he was on top of her. His hands around her neck, her soft skin, his grip tightening. He watched her as a shriek left her throat, swelling, miming, no laughter nor crying, without any emotion.

He only thought, coldly. It was what he had to do. He had to do it properly. A little more, still. Not too much. Excitement, esclusa a forza dal cervello, si prendeva tutto il resto.

The eyes, the temples and the tips of the fingers that throbbed. The dilated pupils glazed over. Everything always gets bigger and then it always gets smaller. Bigger, suddenly, and then again it gets smaller, ever so quickly, like a film sped up. And meanwhile the disease spread, and took over more and more until it reached the centre of the impulses.

A fiery wave flooded her brain. It swirled, violently, against the corroded pillars of her common sense. A wind, an infernal gust defended/stunned her brain.

The cut on his side was pulling open and the makeshift stitches seemed they would give out. He noticed it too late like a detail, fuori campo, a glint.

Her hand was holding something, loosely, and then came the swinging blow. A slash. The clear sound, a sharp lash in the air. 
The gash opened and her blood splattered over the both of us, it was still warm e la faccia ci si impresse, ferma.

Guzzo had many suggestions concerning these final paragraphs:

And she asked, instead, to be free. She was life, like wind, and she couldn't be stopped. She asked him to remain alone. To get used to solitude, like overcoming death, and surrender to the incoherent flow of his visions, to plunge into the screams and voices, shadows and dreams. Not to tame them, nor to keep them captive, but surrender.

He felt something pull at his side, where his wound was. He saw the edges spread and the brink of an open abyss. No blood, starry, black.

A moment later he was on her. His hands around her neck, on her soft skin, his grip tightening. He watched her as a shriek left her throat, and she swelled and waved her hands. He didn't laugh or cry, he felt no emotion.

He only thought, coldly. That's what he had to do.

He could do it properly. A little longer, still. Not too much.

He kicked out the excitement from his brain, but it took all the rest.

His eyes, his temples and his fingertips were throbbing. The dilated pupils glazed over. Everything got bigger and bigger, then smaller and smaller. Suddenly bigger and then again smaller, ever so quickly, like a film sped up. And meanwhile the infection spread and took over more and more until it reached the base of his impulses.

A fiery wave flooded his brain. It swirled, violently, against the eroded pillars of his common sense. A wind, an infernal gust stunned his head.

The cut on his side was pulling more and more and the makeshift stitches seemed on the verge of giving out. He noticed it too late: like a marginal detail, a glint.

His hand was holding something, out of control, then it swung and stroke the blow.

A slash.

A clear sound, a sharp lash in the air.

His gash opened and her blood splattered over it and her face impressed on it, not a move.

I tried to incorporate some of Guzzo's suggestions going into my second translation:

She, instead, was asking to be free. She was life, like the wind, and nothing would stop her. She asked him to be alone. To get used to solitude, like overcoming death, and surrender to the incoherent flow of his visions, to plunge into the screams and voices, shadows and dreams. Not to tame them, nor to keep them captive, but surrender to them.

He felt something pull at his side, where his wound was. It began to rip open and revealed the edge of an abyss. Bloodless, starry, black.

A moment later he was on top of her. His hands were around her the soft skin of her neck, his grip tightening as he strangled her. He watched her swell up, shriek and wave her hands about. He didn't laugh or cry, he felt no emotion.

He was only going through the motions, coldly. It was what he had to do.

He had to do it properly. A little longer, still. Not too much.

Even if his brain resisted it, excitement took cover.

His eyes, his temples and his fingertips throbbed. His dilated pupils glazed over. Everything became bigger and bigger, then smaller and smaller. Then bigger and smaller again, ever so quickly, like a film sped up, Meanwhile the infection flared, spread and then took over all his impulses.

A fiery wave flooded his brain. It swirled, violently, against the compromised pillars of his better judgment. A wind, an infernal gust stunned him.

The cut on his side was pulling open and the makeshift stitches were about to burst. It was too late when he noticed it - an unimportant detail, a glimpse. 
It was his hand and he was holding something it in; swinging out of control, he struck her. A slash.

A clear sound, a sharp cut through the air.

His wound tore open and her blood splattered over him, leaving a print of her still face on it.

In my third and final version I focused on mimicking the tone of the original Italian text, accurately communicating the build-up of suspense and impending doom. Guzzo did this by using short sentences and focussing on action not description which is a departure from his usual style:

She, instead, was asking to be free. She was life, like the wind, and nothing would stop her. She asked him to be alone. To get used to solitude, like overcoming death, and to surrender to the incoherent flow of his visions, to plunge into the screams and voices, shadows and dreams. Not to tame them, nor to keep them captive, but surrender to them.

He felt something pull at his side, where his wound was. It began to rip open and revealed the edge of an abyss. Bloodless, starry, black.

A moment later he was on top of her. His hands were around the soft skin of her neck, their grip tightening. He watched her struggling to breathe, swelling up and moving her hands wildly. He didn't laugh or cry, he felt no emotion.

All he was doing was thinking, coldly. He was only going through the motions, coldly. It was what he had to do.

He would be able to do it properly. A little longer, still. Not too much.

Excitement, shut out forcibly from his brain, took over all the rest of him.

His eyes, his temples and his fingertips throbbed. His dilated pupils glazed over. Everything became bigger and bigger, then smaller and smaller. Then bigger and smaller again, ever so quickly, like a film sped up. And all the while the infection grew and spread, advancing and invading all his impulses.

A fiery wave flooded his brain. It swirled, violently, against the crumbling pillars of his better judgment. A wind, an infernal gust echoed through his head.

The cut on his side was pulling open and the makeshift stitches were about to burst. He noticed it belatedly, like an unimportant detail, a glimmer.

It was his hand holding something; swinging out of control, it struck her. A slash.

A clear sound, a sharp cut through the air.

His wound tore open, and her hot blood splattered into it, and her face pressed into it, unmoving.

This example highlights a number of translation issues, namely grammatical and tonal. The first version I went with was a more literal translation, as I wanted to be sure I was getting the meaning right before focusing on making the translation as literary as possible. I also wanted Guzzo to clarify if I had chosen the right pronouns as I find in Italian the grammar can allow them to be more implicit, whereas in English they must be explicit. This remains something I still have trouble with, discerning the correct ones in certain contexts. This is a glaring example of grammatical equivalence, that is to say there is a notable difference between English and Italian to do with pronoun use and gender and this is something I had to be mindful of as the story's translator when moving between these languages, as explained here by Mona Baker: 
What all this amounts to, among other things, is that in translating pronouns from English to, say, French, Italian, Greek, Spanish, Russian, German or Bahasa Indonesian, decisions may have to be made along such dimensions as gender, degree of intimacy between participants, or whether the reference includes or excludes the addressee. This information may or may not be readily recoverable from the context. Translating in the other direction, from one of the above languages into English, will frequently involve loss of information along the dimensions in question. ${ }^{50}$

While not all of Guzzo's suggestions were useful, they clarified the meaning and intent of this passage. Guzzo also corrected any wrong pronouns which was extremely helpful.

In the second version I was trying to improve the flow of the overall text and while it was an improvement on the previous version, I still felt the tone was not quite right.

Guzzo uses military terms in the following sentence: E intanto il contagio cresceva, avanzava e occupava terreno, fino al centro degli impulse and I felt it was important to replicate this in English. I chose to go with this: "And all the while the infection grew and spread, advancing and invading all his impulses".

As this is the final passage of this story and the climax, it was very important to highlight the urgency and intensity that is present in the Italian in the translation. Guzzo achieves this through his choice of words and specially the syntax. These paragraphs use many very short sentences - some just a few words and a more pared back syntax, very different from Guzzo's usually longer and more descriptive sentences, as in the following example:

A slash. A clear sound, a sharp cut through the air.

Bloodless, starry, black.

A little longer, still. Not too much.

It was what he had to do.

This also highlights John's state of mind - he has gone into an emergency state. He can no longer think clearly, he is acting on survival instincts alone.

With the third version I focused on capturing the immediacy that is so present in these last two paragraphs. While some of the changes were minor, it made a substantial difference to the overall feeling of the text.

My final example from Il vento se ne infischia deals with a section that is representative of the element of Guzzo's style which deals with his flair for unexpected imagery and metaphors and how I went about recreating this in the English text:

\footnotetext{
${ }^{50}$ Mona Baker, In Other Words: a Coursebook on Translation Third Edition (London: Routledge, 2018$), 108$.
} 
Here is the Italian:

E poi, giusto in mezzo al cielo - un gingillo che occhieggiava distrattamente - era appuntata la luna. Un bottone di luna, a rimandare il suo richiamo lucente e millenario. Un occhio aperto che la guardava, la punta di una mammella, il varco minuscolo per uscire dalla sua ferita.

This was my first attempt at translating this section:

A button-like moon, broadcasting its ancient, shining beacon. One eye open that was watching it, her nipple, the smallest way to get out of his wound.

Guzzo made his suggestions:

And right in the middle of the sky - a trinket absently ogling - fixed up there was the moon. A button-like moon, broadcasting its ancient, shining beacon. One open eye that was watching her, like a nipple, the smallest pass to get out of her wound.

In my second translation I focused on trying to create something that would read well in English

And right in the middle of the sky - a trinket absently watching- fixed up there was the moon. A button moon, sending out its shining ancient call. An open eye that watched her, a nipple, a miniscule pathway out of her agony.

And this was my final version:

And right in the middle of the sky, fixed up there was the moon - a trinket absently watching. A button moon, sending out its shining ancient call. An open eye that watched her, a nipple, a miniscule opening out of her agony.

Here the main issue was one of content. The following sentence was particularly difficult to get right as it was very abstract imagery. It took a while for me to comprehend what Guzzo wanted to illustrate.

This was one of the instances where, despite asking Guzzo to explain what the meaning was behind this sentence, his version did not clarify things.

The second version was a little too free and did not retain all the Italian, though I do believe the tone was much improved.

In the third version I focused on the imagery - all things are circular. Using this as a parameter made the image clearer. This type of sentence where there are a few different images tied together by one commonality appear throughout Guzzo's stories. These sentences often posed issues as initially they can seem quite obtuse and take a lot of reworking to find something that works well in the English translation.

There is a vast difference in the sorts of changes I began to make in my later translations. I had honed the stylistic elements that made up Guzzo's tone in English and focused on creating a 
cohesive voice throughout the translation and throughout the collection of short stories. I have the balance between remaining faithful to the original Italian text and focusing solely on the English in a way that wouldn't take away from the original stories, instead hoping to highlight the beauty of Guzzo's writing in the English translation.

\section{Conclusions}

Theory vs practice: finding the balance between theory and practice has been an important aspect of this entire project. While having a basis in translation theory was of great value, it could not compare to the steep but effective learning curve a translator is faced with when starting to translate a work of literature, in my case a collection of short stories. Time and experience were invaluable when it came to finding my style as a translator. I found the study of translation theory to be useful, in particular Mona Baker's concise and practical examples of language differences and ways to address commonly occurring translation issues. I valued reading the experiences of other translators, for example Suzanne Levine's accounts of her translating Guillermo Cabrera Infante and the confidence she had in her translations, even as a novice translator, allowed me to reflect on my own process; yes, they were Guzzo's ideas and images but words on the page in English were mine.

William Weaver deliberated over if the English was too obtuse and contemplated how difficult it was for the reader of the original Italian; in the same way Eco wanted his reader to work to understand the text, so does Guzzo in many ways. This type of theoretical discussion was beneficial when reflecting and analysing the different elements of the translation process and using it as a tool to discuss and embolden important ideas but, overall, my aim for these translations was not to simply provide an academic exercise to discuss abstract theoretical concepts. My main aim was to create stories which could be enjoyed by English readers out of the context of just this thesis. My hope is for the target language audience to experience Guzzo's writing and most importantly enjoy these tales. While it was imperative for these stories to work effectively in the confines of this thesis - I hope they can have a life outside it too.

Where theory was truly useful was when I found examples such as Parks and Weaver that delved explicitly into creating tone and style. Most importantly, both of their discussions use examples that are focussed on issues between English and Italian. It was most reassuring to read that many of the problems I faced in translation were universal issues between the two 
languages. This type of literature had direct impact on my translations. Ultimately it was reflecting on my own process in the light of other's work that brought a greater understanding to the whole project.

Was this case study in Translaboration successful? Ultimately, I believe it was. I am very happy with the resulting translations and I don't think I would have achieved the same result without the translaboration process.

The amount of back and forth between author and translator was crucial in this success, especially as this was my first translation project of this magnitude, but it would most likely have to be adapted in a 'real life' scenario with deadlines and multiple parties involved as it was a very time-consuming process.

The time involved however made the difference between just having input from the author and developing a profound relationship with the writings and inner workings of the author. There are the obvious pros - the translator has peace of mind knowing they are translating what the author actually intended and can get clarification of queries but also having an open line of communication with the author has been one of the most rewarding elements of this process and one that has benefitted the translation too. The better I got to know Guzzo as a person, the better I understood his work and how his mind worked and that allowed me to instil that knowledge in the translation. It brings about a liberty in the way I could translate, an ability to move away from the literal as I found surety in my understanding of the deeper intentions of the author. I think this level of connection can be seen in many of the most successful translator /author partnerships. ${ }^{51}$

The greatest hurdle of the translaboration process was the compromises that needed to be made and making the right choices around those compromises. The importance of maintaining the qualities of a foreign text while ensuring the TL audience were drawn into the flow of the text required constant consideration and recalibration. I needed to develop a thorough understanding of the main differences between the TL and SL and find consistency in the way I addressed those differences. There were also the compromises which needed to be negotiated between Guzzo and myself. I had to meet the obstinacy of the author in his convictions with an equal and equivalent obstinacy of my own to create the best possible version of the translated

\footnotetext{
51 "What started with that barely more than casual first reading has turned into a friendship, a trust, a whole career". Jorge Luis Borges, Selected Poems, trans. Norman Thomas di Giovanni (Harmondsworth: Penguin, 1985), xiii-ix.
} 
text. The exhaustive nature of this quest was, at times, something of a trial, but absolutely, ultimately, lead to a much more effective and finely tuned work.

And finally, the process itself also worked well as an element of this thesis, as there was no shortage of material to delve into, analyse and discuss with regard to the issues and struggles expounded on in the field of translation theory. The opportunity to take the theories and really practice them, to see if they were successful in the translation process, has been the most useful way to implement what I have learnt through readings. Reading other translators' translation diaries, and going through case studies, has been what I have found most useful in reflecting on and seeking to hone my own translation practice, ultimately, what has been most valuable has been translating this collection of short stories. Korean translator, Deborah Smith perfectly describes how I feel about completing this project: “and I understand now what I didn't then: that learning a language is not a progression toward 'mastery,' and that nothing teaches you to translate like actually doing it. I'm glad to have brought the work of a brilliant writer to an international audience". 52

Through this process, I had the opportunity to have some of these stories published in the Journal of Italian Translation and on a national news website ${ }^{53}$ and have been able to extend my translation experience with poetry of other Italian writers. The skills honed through translating Guzzo's poetic prose were well suited to this endeavour. Looking forward, I would like to have this collection of short stories published and continue my translation partnership with Guzzo in producing more translations of his works.

\footnotetext{
${ }^{52}$ Deborah Smith, "What We Talk About When We Talk About Translation," Los Angeles Review of Books, January 11, 2018, https://lareviewofbooks.org/article/what-we-talk-about-when-we-talk-abouttranslation/?fbclid=IwAR0cmSHPupjYVaGJmCCIrzlgbJQ7WgrJeQYxO0C1QLRX0nSvnRvzfU12C80. ${ }^{53} \mathrm{https}: / /$ www.newsroom.co.nz/readingroom/short-story-maradona-by-leonardo-guzzo (accessed January 6 2022).
} 


\section{BIBLIOGRAPHY}

Primary sources:

Guzzo, Leonardo. Le radici del mare. Italy, Pequod, 2015.

Guzzo, Leonardo. Terre emerse. Italy, Pequod, 2019.

Guzzo, Leonardo. Beco. Italy, Pequod, 2021.

$\underline{\text { Secondary sources: }}$

Adamo, Giuliana. "Twentieth-Century Recent Theories on Beginnings and Endings of Novels." Annali D'Italianistica 18 (2000): 49-76. Accessed May 21, 2021. http://www.jstor.org/stable/24008547.

Baker, Mona. In Other Words: A Coursebook on Translation Third Edition. London: Routledge, 2018.

Basalamah, Salah, and Gaafar Sadek. "Copyright Law and Translation: Crossing Epistemologies." The Translator 20, no. 3 (2014): 396-410. Accessed July 4, 2021. https://doi.org/10.1080/13556509.2014.931020.

Bassnett, Susan and Peter Bush (eds). The Translator as Writer. London: Continuum, 2006.

Bassnett, Susan. Translation Studies. London and New York: Routledge, 1988.

Bell, Anthea. "Translation: Walking the Tightrope of Illusion" in Bassnett and Bush, 2006: 58-70.

Boase-Beier, Jean. Stylistic Approaches to Translation. New York, St. Jerome Publishing, 2006.

Boase-Beier, Jean, Lina Fisher, and Hiroko Furukawa. The Palgrave Handbook of Literary Translation. Cham: Springer International Publishing AG, 2018.

Borges, Jorge Luis. Selected Poems. Trans. Norman Thomas di Giovanni. Harmondsworth: Penguin, 1985.

Bouquet, Philippe. "Last och lust, or... the fun of it all." In Translation of Poetry and Poetic Prose, edited by Allèn, Sture. World Scientific Publishing Co Pte Ltd, 1999.

Buzzati, Dino. La boutique del mistero. Milan. Mondadori classici moderni, 1992.

Cambridge Dictionary. Accessed May 20, 2021. https://dictionary.cambridge.org/dictionary/englishitalian/concerned. 
Cavagnoli, Franca. "Italian Authors Meet Australian Authors: The Responsibility of Writers as Translators." Translator (Manchester, England) 23, no. 1 (2017): 83-94.

Cavagnoli, Franca. "Vola Gigino?: Translating David Malouf's Novels into Italian." Southerly 63, no. 1 (2003): 73-78.

Collins Italian Dictionary \& Grammar: 120,000 Translations plus Grammar Tips. London: Collins, 2018.

“Collins Italian Dictionary.” Translations, Definitions and Pronunciations. Accessed May 20, 2021. https://www.collinsdictionary.com/dictionary/english-italian.

Costales Fernández, Alberto. "Collaborative Translation Revisited: Exploring the Rational and Motivation for Volunteer Translation," FORUM. Revue internationale d'interprétation et de traduction / International Journal of Interpretation and Translation 10, no. 1 (2012): 115142.

De Wilde, July. "Diverging Author/Translator Interventions in the Dutch, French and US Translations of Cuban Novel Tres tristes tigres: Some Explanatory Factors. Translation Effects. Selected Papers of the CETRA Research Seminar in Translation Studies 2009, edited by Omid Azadibougar. Ghent University Belgium, 2010. Accessed February 21, 2021. https://www.arts.kuleuven.be/cetra/papers/files/july-de-wilde-diverging-author-translator.pdf

Di Giovanni, Norman Thomas. Lessons of the Master: On Borges and His Work. London: Continuum, 2003.

Eco, Umberto. Experiences in Translation. Translated by Alastair McEwen. Toronto: University of Toronto Press, 2008.

Eco, Umberto. Mouse Or Rat? Translation as Negotiation. London: Orion, 2013.

Gadd Colombi, Anna. Translation as Criticism: Elizabeth Jolley's Mr Scobie's Riddle. Cambridge Scholars Publishing UK, 2018.

Green, Jeffrey. Thinking through Translation. Athens, Georgia: University of Georgia Press, 2010.

Grossman, Edith. Why Translation Matters. New Haven: Yale University Press, 2010.

Hayes, Julie Candler. "Translation as Original Composition: Reading the Work of Pierre Le Tourneur." In Ritual, Routine, and Regime: Repetition in Early Modern British and European Cultures, edited by Clymer Lorna, 201-23. University of Toronto Press, 2006.

Henitiuk,Valerie. “Optical illusions?" In Creative constraints: translation and authorship, edited by Wilson, Rita and Gerber, Leah. Monash University Publishing, 2012.

Kadiu, Silvia. Reflexive Translation Studies: Translation as Critical Reflection. London: UCL Press, 2019. 
Katan, David. Translating Cultures: An Introduction For Translators, Interpreters and Mediators Second Edition. New York Routledge, Taylor \& Francis Group, 2014.

Kundera, Milan. Testaments Betrayed. Translated by Linda Asher. London: Faber, 1995.

Landers, Clifford E. Literary Translation: A Practical Guide. Clevedon, UK; Buffalo: Multilingual Matters, 2001.

Lehka-Paul, Olha. "The Translator's Personality in Translation Process Research." In Personality Matters: The Translator's Personality in the Process of Self-Revision, 65-106. Leuven (Belgium): Leuven University Press, 2020.

Levine, Suzanne Jill. The Subversive Scribe: Translating Latin American Fiction. Saint Paul: Graywolf Press, 1991.

Levine, Suzanne J. "Writing as Translation: Three Trapped Tigers and a Cobra." MLN 90, no. 2 (1975): 265-77. Accessed May 21, 2021. doi:10.2307/2906862.

Levine, Suzanne Jill. "From 'Little Painted Lips" to Heartbreak Tango.” In The Art of Translation: Voices from the Field, edited by Rosanna Warren. Boston: Boston University Press. 1989, 30-46.

Lunsford, Andrea A. Writing Together: Collaboration in Theory and Practice. Bedford Bks St Martin's, 2011.

Maher, Brigid. Recreation and Style Translating Humorous Literature in Italian and English. Amsterdam: John Benjamins Publishing Company, 2011.

Markish, Shimon. "No theory, please!" In Translation of Poetry and Poetic Prose, edited by Sture Allèn. World Scientific Publishing Co Pte Ltd, 1999.

Orero, Pilar, and Sager, Juan C., eds. Translator's Dialogue: Giovanni Pontiero. Amsterdam: John Benjamins Publishing Company, 1997.

Parks, Tim. Translating Style, A Literary Approach to Translation, A Translation Approach to Literature Second Edition. New York, Routledge, 2014.

"Parts of Boats and Ships." Macmillan Thesaurus. Accessed May 20, 2021. https://www.macmillanthesaurus.com/topics/parts-of-boats-and-ships.

Pym, Anthony. Exploring Translation Theories. New York: Routledge, Taylor \& Francis Group, 2010 .

Pym, Anthony. "On the Social and Cultural in Translation Studies". In Sociocultural Aspects of Translation and Interpreting, by Anthony Pym, Miriam Shlesinger and Zuzana Jettmarová. Amsterdam: John Benjamins Publishing Company, 2006. 
Pym, Anthony. The Translator as Author: Two Quixotes. Translation and Literature, 14 (2005): 71 81. Accessed January 14, 2021. 10.3366/tal.2005.14.1.71.

Rabassa, Gregory. "No Two Snowflakes Are Alike: Translation as Metaphor.” In The Craft of Translation, edited by John Biguenet and Rainer Schulte. Chicago and London: University of Chicago Press, 1989.

Rabassa, Gregory. The Ear in Translation: The World of Translation. New York: PEN American Center, 1971.

Rion, Rosanna. "Translation and Tradition: The Translator As Mediator between Two Literary Systems." Coolabah 3, 2009. Accessed April 7, 2021. https://doi.org/10.1344/co20093164169

Robinson, Douglas. Western Translation Theory from Herodotus to Nietzsche. New York: St. Jerome Publishing, 1997.

Roseen, Ulla. "Listening to the voice of the author". In Translation of Poetry and Poetic Prose, edited by Sture Allèn. World Scientific Publishing Co. Pte Ltd, 1999.

Rossi, Cecilia. "Literary translation and disciplinary boundaries." In The Routledge Handbook of Literary Translation, edited Kelly Washbourne and Ben Van Wyke. Abingdon: Routledge, 2018. Accessed 24 Jan 2022, Routledge Handbooks Online.

Schiavon, Francesco. 'Fantastic News': Literary Modes of Representation in Dino Buzzati's Journalism. London: University of London, 2013.

Sharfi Mohamed, Kamal Osman. "Literary Translation as a Means of Creativity." In Global Journal of Arts, Humanities and Social Sciences 4, no.1 (2016): 49-52.

Shuttleworth, Mark and Cowie, Moira. Dictionary of Translation Studies. New York: Routledge, Taylor \& Francis Group, 2014.

Smith, Deborah. "What We Talk About When We Talk About Translation." Los Angeles Review of Books. January 11, 2018. https://lareviewofbooks.org/article/what-we-talk-about-when-wetalk-abouttranslation/?fbclid=IwAR0cmSHPupjYVaGJmCCIrzlgbJQ7WgrJeQYxO0C1QLRX0nSvnR vzfU12C80.

St. André, James (ed.). Thinking through Translation with Metaphors. Manchester: St. Jerome, 2010.

Steyn, Jan. "Showdown at the translation saloon on Lawrence Venuti's "Contra Instrumentalism: A Translation Polemic". Los Angeles Review of Books, August 2,

2020. https://lareviewofbooks.org/article/showdown-at-the-translation-saloon-on-lawrencevenutis-contra-instrumentalism-a-translation-polemic/.

Szymanska, Kasia. "Literary Metatranslations: When Translation Multiples Tell Their Own Story." In Prismatic Translation, edited by Reynolds Matthew, 140-55. Cambridge: Modern Humanities Research Association, 2019. 
“TRABUCCO” In "Enciclopedia Italiana". Accessed 22/02/2019.

https://www.treccani.it/enciclopedia/trabucco_\%28Enciclopedia-Italiana\%29/.

Thomas, Di Giovanni Norman, and Jorge Luis Borges. In Memory of Borges. London: Constable in association with the Anglo-Argentine Society, 1988.

Vanderschelden, Isabelle. "Authority in Literary Translation: Collaborating with the Author."

Translation Review 56, no. 1 (1998): 22-31. Accessed November 24, 2021.

https://doi.org/10.1080/07374836.1998.10523727.

Venuti, Lawrence. The Scandals of Translation : Towards an Ethics of Difference. London: Routledge, 1998.

Venuti, Lawrence. The Translator's Invisibility: A History of Translation. London and New York: Routledge, 1995.

Weaver, William. "Pendulum Diary.” Southwest Review 75 (1990): 150-178.

Weinberger, Eliot. "The role of the author in translation". In Translation of Poetry and Poetic Prose, edited by Sture Allèn. World Scientific Publishing Co. Pte Ltd, 1999.

Wilson, Rita and Gerber, Leah. "Introduction". In Creative Constraints: Translation and Authorship, edited by Rita Wilson and Leah Gerber. Melbourne: Monash University Publishing, 2012.

Zanotti, Serenella. "The Translator and the Author: Two of a Kind." In The Translator as Author: Perspectives on Literary Translation, edited by Claudia Buffagni, Beatrice Garzelli and Serenella Zanotti. London: Transaction Publishers, 2011. 